SADALLA DOMINGOS

\title{
ANÁliSE E AVALIAÇÃo DE POSSIBILIDADES \\ DE SISTEMATIZAÇÃO E GESTÃO INTEGRADA \\ DE SISTEMAS DE INFRA-ESTRUTURA URBANA
}

\begin{abstract}
Tese apresentada à Escola Politécnica da Universidade de São Paulo para obtenção do

Título de Professor Doutor junto ao

Departamento de Engenharia de Construção

Civil.
\end{abstract}

São Paulo 


\section{ANÁLISE E AVALIAÇÃO DE POSSIBILIDADES DE SISTEMATIZAÇÃO E GESTÃO INTEGRADA DE SISTEMAS DE INFRA-ESTRUTURA URBANA}

Tese apresentada à Escola Politécnica da Universidade de São Paulo para obtenção do Título de Professor Doutor junto ao Departamento de Engenharia de Construção Civil.

Área de Concentração:

Orientador:

Prof. Dr. Witold Zmitrowicz

São Paulo 


\section{FICHA CATALOGRÁFICA}

Domingos, Sadalla

Análise e avaliação de possibilidades de sistematização e gestão integrada de sistema de infra-estrutura urbana / S. Domingos. -- São Paulo, 2004.

p.

Tese (Doutorado) - Escola Politécnica da Universidade de São Paulo. Departamento de Engenharia de Construção Civil.

1.Infra-estrutura urbana 2.Gestão urbana 3.Gestão integrada 4.Planejamento territorial regional 5.Planejamento territorial urbano I.Universidade de São Paulo. Escola Politécnica. Departamento de Engenharia de Construção Civil II.t. 
Dedico este trabalho de pesquisa:

Como minha homenagem e minha contribuição à formação da Nação Brasileira.

Aos meus pais, jovens imigrantes libaneses, Tufi e Fargette, que escolheram o Brasil para viver.

Aos meus filhos, Thiago e Carolina. 


\section{AGRADECIMENTOS}

Ao amigo e orientador Prof. Dr. Witold Zmitrowicz, pelas diretrizes fundamentais deste trabalho e pela permanente disposição ao diálogo.

Ao caro Prof. Dr. Alex Kenya Abiko, pelo apoio, incentivo e orientação na definição e elaboração do Plano de Pesquisa.

Ao Prof. Dr. Jair Minoro Abe, pelos seus ensinamentos de lógica paraconsistente.

Ao Prof. Fábio Romeu de Carvalho, pela sua contribuição à consolidação deste trabalho.

Aos oito especialistas, que em inúmeras reuniões, dispuseram-se a entender o objeto desta tese e colaborar para a consecução do estudo de caso.

Aos professores Mário Maeda Junior e Nélsio Terashima pelo apoio e preparação das planilhas de cálculo.

A todos os meus amigos e colegas de trabalho em reconhecimento aos ensinamentos recebidos, ao longo de nosso convívio. Em especial agradeço à Waléria C. Batista e Tânia B. Labate pela edição e à Paula de Oliveira pelos desenhos.

À minha querida mulher, pela sua alegria e seu estímulo à elaboração desta Tese. 


\section{RESUMO}

O presente trabalho apresenta inicialmente algumas evidências da necessidade de promover o entendimento abrangente dos sistemas de infra-estrutura apoiando-se sobre trabalhos realizados no Brasil e no Exterior. Em seguida, propõe-se a compreensão homogeneizada dos sistemas e sua apresentação conjunta e sistematizada no formato de matriz, a partir de critérios comuns como o estudo dos fluxos, a distinção entre sistemas e serviços e as diferentes escalas - central, arterial e capilar - de cada sistema e sub-sistema.

Após esta sistematização, propõe-se níveis crescentes de integração entre os sistemas em uma determinada unidade territorial de análise; numa primeira opção metodológica, a gestão integrada proposta relaciona-se às suas localizações e espaços necessários; numa segunda opção, a gestão integrada desenvolve-se mediante avaliação de indicadores de desempenho dos serviços, os quais são uniformizados para todos os sistemas, propiciando um entendimento abrangente de locais e sistemas associados às condições de oferta e demanda dos serviços; a terceira opção propõe a gestão integrada intercambiando dados, informações e critérios operacionais entre os diferentes sistemas.

Nesta $3^{\text {a }}$ opção, a gestão integrada com procedimentos clássicos (hipótese 3/1) necessita de base de dados consistente e disponível em cada sistema, para iniciar-se então suas compatibilizações e daí elaborar modelos operacionais, associando-os. Considerando que as bases de dados são normalmente indisponíveis ou organizadas segundo critérios próprios de cada sistema, propõe-se construir e processar outra Base de Dados (hipótese 3/2) obtida através dos critérios não clássicos, relacionadas à Lógica Paraconsistente.

Aplica-se então este método não clássico a um estudo de caso de navegação de um rio urbano no Município de São Paulo. 
Finalmente são elencadas conclusões e são indicados possíveis caminhos de aplicabilidade destes métodos. 


\section{RESUMÉ}

Dans son début, ce rapport présent quelques évidences sur la necessité de promouvoir une compréhension d'ensemble des systèmes d'infrastructure, en s'appuyant sur des études faites au Brésil et a l' étranger. Ensuite, il est proposé la compréhension homogéneisé des systèmes et sa présentation rassemblée et systématisée dans le format d' une matrice, a partir des critéres communs comme l'étude des flux, la distinction entre systèmes et services et les differentes échelles centrale, artérielle et capillaire - de chaque système et sous-système.

Après cette systématisation, ce sont proposés des niveaux d'integration élargis entre les systèmes dans une unité territoriale d'analyse determinée. Dans une première option méthodologique, la gestion integrée proposée est relacionée avec ses localizations et espaces physiques necessaires. Dans une deuxième option, la gestion integrée est developée par l'avaliation des indicateurs d'accomplissement des services, qui sont uniformisés pour tous les systèmes, ce qui rend possible une compréhension complète des locaux et des systèmes associés aux conditions d'offre et demande des services. La troisième option propose la gestion integrée en échangeant des données, des informations et des critères opérationnels entre les différents systèmes et ses centres de controle opérationnel.

Dans cette troisième option, la gestion integrée avec des procedures classiques a besoin d'une base de données consistantes et disponibles dans chaque système, pour possibiliter le commencement de ses compatibilisations et d'elaboration des modèles opéracionnaux en faisant son association. Considerant que les bases de données sont normalement non disponibles ou organisées selon des critères particuliers de chaque système, il est proposé de construire (et processer) une autre base de données obtenue par des crytères non classiques, relacionées a la Logique Paraconsistente.

Ensuite cette méthode non classique est apliquée a une étude de cas sur la navigation d'une rivière urbaine dans la ville de São Paulo. 
Finalement, les conclusions sont listées et les chemins pour l'applicabilité de cette méthode sont indiqués. 


\section{SUMÁRIO}

1. INTRODUÇÃO.................................................................................................................. 1

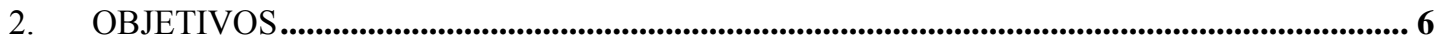

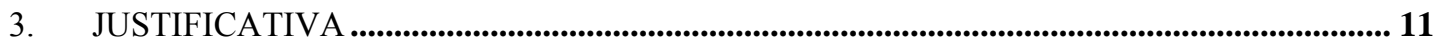

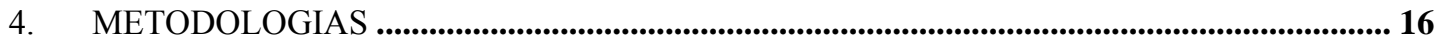

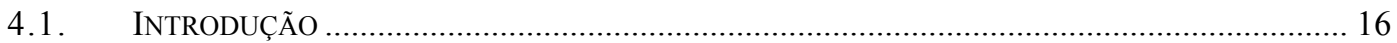

4.2. A DEFINIÇÃO DE MATRIZ DOS SISTEMAS DE INFRA-ESTRUTURA URBANA............................. 16

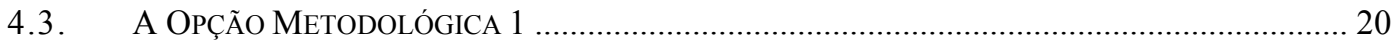

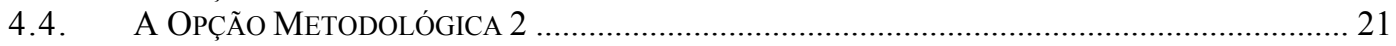

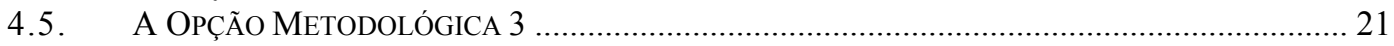

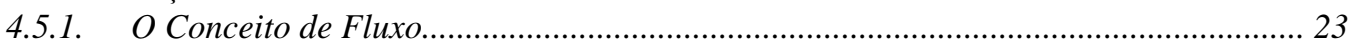

4.5.2. O Caminho Metodológico 3/1 ................................................................................ 27

4.5.3. O Caminho Metodológico 3/2 ……………………………………………….......... 29

4.5.3.1 A Lógica Paraconsistente Anotada com graus de crença (evidência favorável) e descrença (evidência contrária) …………………………………………………………………………….... 33

4.6. Síntese das Proposições Metodológicas e Método Adotado …………..................... 46

5. ESTUDO DE CASO ESCOLHIDO: A NAVEGABILIDADE DO CANAL DO RIO PINHEIROS, A OESTE DO MUNICÍPIO DE SÃO PAULO .................................................................49

6. A PROPOSIÇÃO “TORNAR NAVEGÁVEL O CANAL DO RIO PINHEIROS SITUADO A OESTE DO MUNICÍPIO DE SÃO PAULO" ................................................................................54

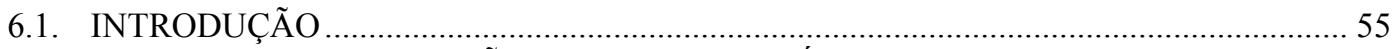

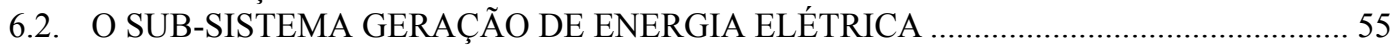

6.2.1. Descriçãa Histórica ................................................................................................... 55

6.2.2. Situação Atual ......................................................................................................... 55

6.2. O SISTEMA RODOVIÁRIO AFETO À UTA CANAL DO RIO PINHEIROS...................... 55

6.3. O SISTEMA FERROVIÁRIO AFETO À UTA CANAL DO RIO PINHEIROS .................. 55

6.4. O SISTEMA ESGOTOS AFETO À UTA CANAL DO RIO PINHEIROS ........................... 55

6.5. O SISTEMA RESÍDUOS SÓLIDOS AFETO À UTA DO CANAL DO RIO PINHEIROS 55

6.5.1. Os Sistemas de Limpeza Pública Municipais ................................................................. 55

6.5.2. O Sub-sistema Dragagem para Desassoreamento do Canal do Pinheiros ................... 55

6.6. O SISTEMA DRENAGEM AFETO À UTA CANAL DO RIO PINHEIROS ...................... 55

6.7. AVALIAÇÃO DA PROPOSIÇÃO NO QUADRO GERAL DOS SISTEMAS DE INFRA-

ESTRUTURA NA UTA CANAL DO RIO PINHEIROS.............................................................. 55

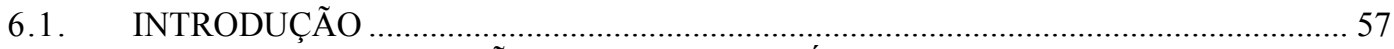

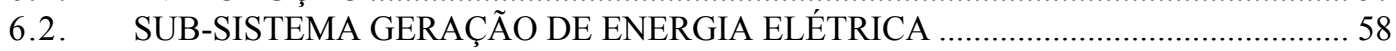

6.2.1. Descrição Histórica ............................................................................................. 58

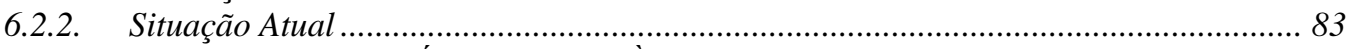

6.3. O SISTEMA RODOVIÁRIO AFETO À UTA CANAL DO RIO PINHEIROS ................. 84

6.4. O SISTEMA FERROVIÁRIO AFETO À UTA CANAL DO RIO PINHEIROS .............. 88

6.5. O SISTEMA ESGOTOS AFETO À UTA CANAL DO RIO PINHEIROS ……................. 90

6.6. O SISTEMA RESÍDUOS SÓLIDOS AFETO À UTA CANAL DO RIO PINHEIROS.. 94

6.6.1. Os Sistemas de Limpeza Pública Municipais ................................................................. 94

6.6.2. O Sub-sistema Dragagem para Desassoreamento do Canal do Pinheiros ................... 95

6.7. O SISTEMA DRENAGEM AFETO À UTA CANAL DO PINHEIROS …….................... 99

6.8. AVALIAÇÃO DA PROPOSIÇÃO NO QUADRO GERAL DOS SISTEMAS DE

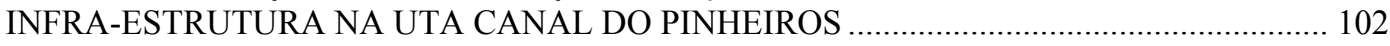

7. OS ESPECIALISTAS E SUAS AVALIAÇÕES: A BASE DE DADOS PARACONSISTENTE

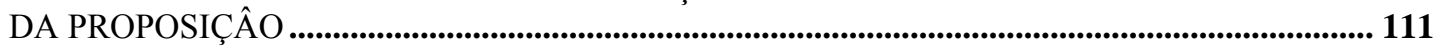


8. O PROCESSAMENTO DA BASE DE DADOS PARACONSISTENTE

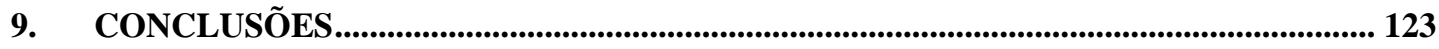

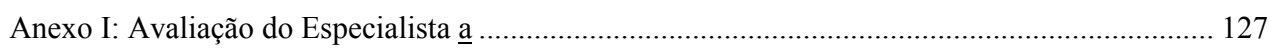

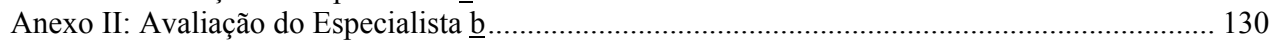

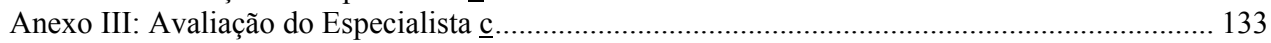

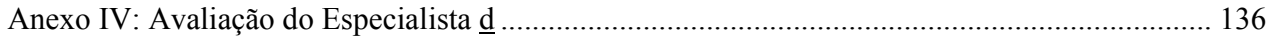

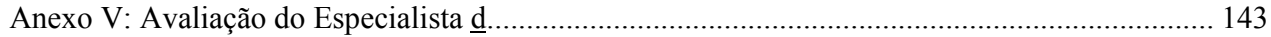

Anexo VI: Avaliação do Especialista f…........................................................................... 146

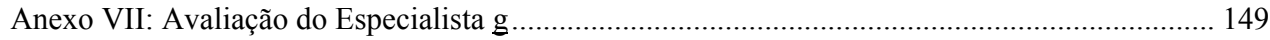

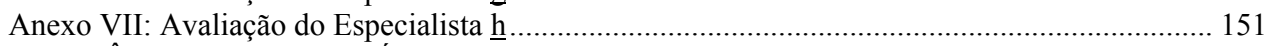

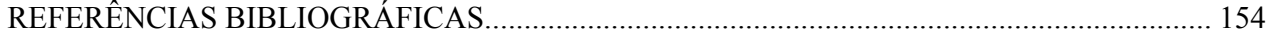




\section{LISTA DE FIGURAS E DESENHOS}

FIG. 1 - Sinais de entrada binários, onde $\mu_{1}$ e $\mu_{2}$ valem 0 ou 1 , independentemente pág. 37

FIG. 2 - Reticulado associado à LPA2v representado por um QUPC com discretização dos graus de crença e de descrença 10 e resolução 100 - pág. 37

FIG. 3 - Rede de sistema especialista paraconsistente para análise da proposição pág. 45

FIG. 4 - Metodologias - Esquema-síntese das proposições - pág. 48

Tabela 1 - pág. 39

Tabela 2 - pág. 39

Desenho 1 - Metodologia 1 - pág.22

Desenho 2 - Metodologia 2 - pág. 24

Desenho 3 - Metodologia 3/1 - pág. 28

Desenho 4 - Metodologia 3/2 - pág. 32

Desenho 5 (Proposição) - pág. 60

Desenho 6 (Proposição) - pág. 61

Desenho 7 (Proposição) - pág. 56

Desenho 8 (Proposição) - pág. 81

Desenho 9 (Proposição) - pág. 82

Desenho 10 (Proposição) - pág. 87

Desenho 11 (Proposição) - pág. 91

Desenho 12 (Proposição) - pág. 93

Desenho 13 (Proposição) - pág. 98

Desenho 14 (Proposição) - pág. 100

Desenho 15 (Proposição) - pág. 103

Fotos 1 a 12 da Proposição - pág. 67 a 78 
Quadro 1 - pág. 19

Quadro 2 (Proposição) - pág. 105

Quadro 3 (Proposição) - pág. 108

Quadro 4: Base de Dados Paraconsistente com Avaliações dos Especialistas pág. 112

Quadro 5: Base de Dados Paraconsistente - Processamento - pág. 121

Diagrama 1 - pág. 114

Diagrama 2 - pág. 115

Diagrama 3 - pág. 117

Diagrama 4 - pág. 118

Diagrama 5 - pág. 125

Diagrama 6 - pág. 126 


\section{LISTA DE ABREVIATURAS E SIGLAS}

ABRATT - Associação Brasileira de Tecnologia Não-destrutiva APM - Associação Paulista de Municípios

APWA - American Public Works Association

CPTM - Companhia Paulista de Trens Metropolitanos

EMAE - Empresa Metropolitana de Águas e Energia

ENPC - École Nationale de Ponts et Chanssées

LATTS - Laboratoire Techniques Territories et Societés

LIMPURB - Departamento de Limpeza Urbana

NSF - National Science Foudantion - EUA

PMSP - Prefeitura do Município de São Paulo

QUPC - Quadrado unitário no plano cartesiano

SABESP - Companhia de Saneamento Básico do Estado de São

SIURB - Secretaria de Infra-Estrutura Urbana

UTA - Unidade Territorial de Análise 


\section{INTRODUÇÃO}

As atividades básicas que são desenvolvidas nas cidades - $\underline{\text { morar, }}$ produzir, consumir, circular, conviver, divertir-se etc - dependem do suporte propiciado pelos sistemas de infra-estrutura disponíveis. Da qualidade do desempenho dos diversos sistemas, enquanto provedores de serviços para os habitantes e os usuários das cidades, corresponderá em grande medida a qualidade dessas atividades, ou seja, a qualidade da própria vida urbana, considerada como o exercício amplo e coletivo das diversas vocações e aptidões humanas ali presentes.

Os diversos sistemas, que propiciam a sustentabilidade da vida urbana, constituem-se em provedores de serviços que podem ser avaliados segundo parâmetros de quantidade, qualidade, regularidade, universalidade, imprescindibilidade, etc , assim como em relação às repercussões de cada um dos sistemas sobre os outros numa determinada unidade do espaço geográfico das cidades. Esta unidade de análise poderá constituir-se num espaço territorial amplo onde diversas atividades humanas e sistemas de infra-estrutura estejam presentes, ou até espaços mais restritos, característicos de edifícios ou edificações contíguas, onde haja predomínio de uma determinada atividade.

A priori propõe-se que a análise visando sistematizar e integrar a gestão dos sistemas de infra-estrutura urbana e serviços prestados seja ampla e extensiva, incluindo todos os sistemas, todos os seus respectivos serviços e todas as suas interrelações. Embora tal premissa metodológica implique numa notável complexidade da análise a ser feita, acredita-se que ela decorra, de modo imperativo, da impossibilidade de eleger, antecipadamente, alguns sistemas de infra-estrutura mais relevantes. Esta impossibilidade decorre da multiplicidade de sítios diferenciados aonde cidades foram localizadas, com grandes diversidades de situações topográficas, climáticas, tecnológicas, culturais, econômicas, sociais, antropológicas etc. Este fato fundamental - a diversidade dos sítios urbanos - implica a necessidade de conceber, implantar e operar sistemas de infra-estrutura compatíveis com os recursos disponíveis e as necessidades sócio-econômicas presentes e futuras. Como exemplo 
pode-se citar que sistemas de transporte hidroviário de passageiros podem ser relevantes para algumas cidades e inexistentes em outras, onde podem ser significativos sistemas de transportes cicloviários pelas condições topográficas planas e outros fatores. Ressalta-se finalmente, ratificando a diretriz de análise de todos os sistemas, seus serviços e suas inter-relações, que um dos objetivos primordiais da pesquisa é propor uma abordagem metodológica genérica, adotável para toda e qualquer unidade do espaço urbano das cidades.

Para que o problema central - sistematizar e integrar a gestão dos sistemas - seja correta e completamente enunciado (o que representa um primeiro e importante resultado dos estudos), faz-se necessário responder a uma questão inicial: haverá nexo (entendido como relação entre coisas e idéias) entre os sistemas de infraestrutura urbana que ofertam serviços para usuários presentes em determinada unidade territorial do espaço urbano?

Considera-se que a resposta cabal e completa a esta questão constitui um dos objetivos principais da Tese, ou seja, identificar os vínculos entre os sistemas e destes com os usuários, numa unidade territorial de análise do espaço urbano, e estudar os diversos atributos desses vínculos.

Como alguns exemplos desses nexos ou vínculos entre sistemas pode-se citar o sistema rodoviário e o sistema de drenagem, o sistema de distribuição de energia elétrica e o sistema de água, etc. Como exemplos de vínculos ou nexos entre sistemas e usuários, pode-se citar os resultados de campanhas de conservação de energia elétrica, de água potável etc, dirigidas ao engajamento dos usuários.

Assim, para o desenvolvimento da pesquisa optou-se pela análise e identificação de nexos entre os sistemas e serviços, considerando-os em relação a três domínios distintos: o domínio dos Usuários (U) entendido como o universo dos beneficiários dos sistemas, ou seja, os consumidores dos serviços; o domínio do Espaço Urbano (E), considerado como o território, suas edificações e seus sistemas de infraestrutura; e o domínio do Estágio de Desenvolvimento (D), considerado como o 
conjunto das relações que se estabelecem entre provedores e usuários dos serviços urbanos, a partir das condições educacionais, sanitárias, sociais, econômicas, tecnológicas, ambientais etc.

Em relação ao domínio dos Usuários, constata-se que um determinado usuário solicita ou deixa de solicitar cada um dos diversos sistemas de infra-estrutura, promovendo, ao longo de um determinado período de tempo, uma integração individual de cada um dos serviços utilizados; ao se considerar o coletivo dos usuários, configura-se a integração desse conjunto de usuários para cada um dos sistemas.

Desta forma, pode-se enunciar que "usuários $\underline{\mathrm{U}}$ presentes num determinado momento $\underline{\mathrm{t}}$ no interior de um Espaço Urbano $\underline{\mathrm{E}}$, solicitam dos sistemas $\underline{\mathrm{S}}_{1}, \underline{\mathrm{S}}_{2}----\underline{\mathrm{S}}_{\mathrm{n}}$ a oferta dos serviços $\underline{\mathrm{S}}_{1}, \underline{\mathrm{S}}_{2} \ldots \underline{\mathrm{S}}_{\mathrm{m}} ”$.

Acrescentando-se a esta constatação do nexo Usuários e Espaço, o domínio do Estágio de Desenvolvimento, pode-se afirmar que um determinando sistema $\underline{S}_{\mathrm{i}}$ ofertará serviços correspondentes $\underline{S}_{i}$ subordinando-se a diversos tipos de restrições: aquelas relacionadas às capacidades físicas do sistema $\underline{S}_{i}$ e de sub-sistemas afetos, as relativas às capacidades econômica e financeira dos usuários, outras referentes aos seus estágios educacional, de saúde, ambientais etc.

Assim, a avaliação do nexo entre $\underline{\mathrm{U}} \mathrm{e} \underline{\mathrm{E}}$ necessita acrescentar hipóteses relativas às capacidades físicas e tecnológicas dos sistemas, às disponibilidades financeiras (ou de renda) dos usuários, às condições de saúde etc.

Desta forma, com as propriedades alinhadas para os domínios $\underline{\mathrm{U}}, \underline{\mathrm{E}} \mathrm{e} \underline{\mathrm{D}}$, pode-se compor um Sistema Urbano de Infra-estrutura (SUI) segundo um critério lógicodedutivo e não-contraditório.

Ressalte-se todavia, que os três domínios considerados, além de não esgotarem todo o conjunto de domínios que influenciam o nexo entre os sistemas, guardam entre si 
aspectos contraditórios que até hoje não permitiram propor um entendimento e um equacionamento conexo entre os sistemas e serviços no Espaço Urbano em função do tempo, já que os sistemas e serviços integram pelas suas condições de contigüidade, enquanto os estágios de desenvolvimento promovem a segregação espacial de forma sistemática.

Neste ponto é que se apresenta, o que se pode denominar um paradoxo dos sistemas de infra-estrutura urbana. Se de um lado, para universalizar os serviços, cada um dos sistemas torna-se mais abrangente e mais complexo, necessitando dos trabalhos de profissionais específicos destes campos de atividades - os especialistas, por outro, ao expandirem-se, os sistemas solicitam, interferem, colidem com os demais sistemas urbanos, o que torna necessário a compreensão e a atuação sobre o conjunto das interdependências entre os sistemas. Nesta situação, solicitando o concurso de profissionais que conheçam os domínios e sistemas de forma abrangente - os ecléticos - que tenham evoluído (ou possam evoluir), da sua vivência profissional setorial para relacionarem-se com outros especialistas de outros sistemas afetos.

Além disso, este ecletismo aplica-se também às situações de emergência, quando um fato externo perturba tão grave e profundamente os sistemas, que as relações anteriores entram em colapso, emergindo um outro tipo de relação que prevalece sobre as anteriormente vigentes. É por exemplo o caso de uma chuva solicitando os sistemas de drenagem urbana que afetam o sistema de tráfego; ou o caso de uma onda de altas temperaturas, que exaure mais rapidamente os reservatórios e mananciais de água; ou eventuais campanhas de economia e conservação de energia, de água, de circulação etc, que promovem mudanças de hábito dos usuários, reconfigurando em outras bases os padrões de nexo entre os sistemas.

Porém, é necessário destacar que os nexos permanecem válidos, mudando os paradigmas dessas relações para novos pontos de equilíbrio, os quais poderão ser novamente alterados para novas configurações, num cenário extremamente dinâmico, próprio das sociedades e cidades em processo de consolidação como as do nosso País, mas também freqüentes em sociedades já estabilizadas. 
Desta forma, propõe-se um conjunto de metodologias de complexidades graduais, que caminhem para abordagens mais complexas, para considerar que as relações entre sistemas de infra-estrutura, serviços, territórios, usuários, etc podem situar-se num cenário de bases exatas, o qual deverá porém, ser ampliado substancialmente para considerar situações "não-exatas" eventualmente de maior relevância que aquelas anteriores. 


\section{OBJETIVOS}

O objetivo geral da Tese "Análise e Avaliação de Possibilidades de Sistematização e Gestão Integrada de Sistemas de Infra-estrutura Urbana" é propor métodos formais para consolidar as informações disponíveis sobre os sistemas e as redes de infraestrutura existentes numa determinada área territorial no espaço geográfico das cidades, sistematizar tais informações segundo critérios coerentes para sua homogeneização e viabilizar o estabelecimento de padrões de comparação entre os diversos sistemas, visando avaliar as relações entre a oferta e demanda dos serviços e com isso identificar oportunidades de atuação para os agentes públicos, privados, comunitários etc, que regulam, que operam e que utilizam estes sistemas.

Este objeto geral tem seu desdobramento prático na constatação cotidiana dos problemas do ambiente construído das cidades brasileiras, relacionados à convivência, num mesmo espaço geográfico, de situações conflitantes dos sistemas de infra-estrutura entre si e destes com a população residente e usuária destes sistemas. Esta visão pragmática orienta o trabalho de pesquisa, quando se propõe uma abordagem extensiva e completa de todos os sistemas de infra-estrutura, pois que os problemas constatados referem-se, via de regra, às interferências entre os diversos sistemas e sub-sistemas instalados, pelo grau de excelência de um sistema que convive, eventualmente, com estágios de obsolescência de outros sistemas e subsistemas.

Ou seja, os conflitos que se estabelecem e podem ser observados em diversos estágios dos processos de urbanização - ocupação incipiente, adensamento, diversificação dos usos das edificações, despovoamento, desindustrialização, verticalização etc, reproduzem-se em relação aos sistemas de infra-estrutura, que podem ser incipientes, suficientes, deficitários, obsoletos, ociosos etc.

Como exemplos destas constatações, podem ser destacadas a referência "Penser la Ville” (Ansay e Schoonbrodt 1989), uma coletânea de textos filosóficos que propõe “...reconstruir as problemáticas abrangentes, resistir à segmentação...” para “....agir 
pela cidade..."; a referência "Deteriorização das Cidades" (Abiko 1992), que define características da infra-estrutura e de edificações precárias, comprometendo níveis de qualidade adequadas da vida urbana; o Texto Técnico "Infra-estrutura Urbana" (Zmitrowicz e De Angelis Neto 1997) que conceitua, classifica, avalia custos e estabelece critérios para expandir a oferta de sistemas de infra-estrutura; a linha de pesquisa Infra-estrutura e Estruturação de Espaços Urbanos do PCC / EPUSP (http://pos.pcc.usp.br/linhas.htm); o Boletim Técnico "Estruturação Urbana: Conceito e Processo" (Zmitrowicz 1998) que discute conceitos de estrutura urbana e processos afetos, ressaltando a questão dos fluxos e das rotinas no espaço urbano; a referencia "A conectividade das redes de infra-estrutura e o espaço urbano de São Paulo noas anos 90" (Silva 1999) referência "Urbs Nostra" (Figueiredo Ferraz 1991) que adota uma visão abrangente e multidisciplinar de diversas questões urbanas principalmente da Cidade de São Paulo e região, além de inúmeros trabalhos de pesquisa realizados e em andamento em diversas unidades da USP e em outras universidades, que poderiam caber genericamente no âmbito do que se denomina produção e sustentabilidade do espaço urbano.

Para entendimento e consecução do objetivo deste Plano de Pesquisa, torna-se necessário também destacar e considerar conceitos de dois autores relacionados a seguir, que são fundamentais para posicionar os sistemas de infra-estrutura no contexto geral das cidades.

No capítulo "Por uma Geografia das Redes" da obra "A Natureza do Espaço, Técnica e Tempo. Razão e Emoção" (Santos 1999), o autor Milton Santos afirma categoricamente que nas cidades, “...a existência das redes é inseparável da questão do poder..."; na mesma obra, ao propor uma visão mais circunstanciada deste aspecto, reafirma que “...onde as redes existem, elas não são uniformes. Num mesmo subespaço, há uma superposição de redes, que inclui redes principais e redes afluentes ou tributárias, constelações de pontos e traçados de linhas. Levando em conta seu aproveitamento social, registram-se desigualdades no uso e é diverso o papel dos agentes no processo de controle e de regulação do seu funcionamento." 
Estas incisivas afirmações juntam-se aos conceitos definidos na introdução de sua outra obra "Metrópole Corporativa Fragmentada - o caso de São Paulo" (Santos 1990), quando propõe analisar “...a cidade na sua materialidade...” e que, além disso, "...o urbano tanto pode ser mais, como pode ser menos que a cidade; e que, sem o entendimento desta, considerada em uníssono como corpo e ação, a interpretação do urbano é acanhada e insuficiente."

Também dentro da gama de conceitos de Milton Santos, cabe destacar trecho da palestra proferida no I Simpósio Nacional de Geografia (Santos 1994), sob o título “Tendências da Urbanização Brasileira no Fim do Século XX”, quando afirma “...que diferenciações regionais deverão e poderão ser vistas pelos graus diversos de organização do território, análise que supõe a consideração dos dados materiais e não materiais, isto é, dos sistemas de engenharia e dos sistemas sociais, cujo conjunto define o espaço produtivo, soma que se dá entre o espaço produzido e a ação produtiva..."; continuando, afirma ainda que "...o conhecimento dos sistemas de engenharia presentes em cada área é, pois, um dado analítico fundamental, pois nos instrui sobre as possibilidades e os limites da ação dos sistemas sociais."

Dentro do conjunto de textos selecionados na obra "Estas Redes que nos Governam?" (Gariépy e Marié, organizadores, 1997), obtidos no desenvolvimento de projeto de pesquisa "Gestão de Infra-estrutura", realizado por 17 pesquisadores da França e Canadá no período de 1995-97, o engenheiro e sociólogo Pierre Veltz, na sua contribuição intitulada "Temporalidades e Representações da Eficácia: a Cidade, os Territórios e as Empresas”, conceitua que “...ao contrário dos Estados-nações, que dispõem de meios de regulação organizados...”, “...as cidades regulam-se quase exclusivamente pelos mercados, isto é, pela mobilidade generalizada dos recursos. E elas são predominantemente sistemas francamente abertos. Elas dispõem de ferramentas de regulação social, mas que não são comparáveis, pela abrangência, aos mecanismos redistributivos dos Estados-provedores. Elas são formadas pelo cruzamento de múltiplos sistemas sócio-técnicos que são objeto de regulações específicas, independentes e contraditórias." 
Embora Veltz tenha analisado basicamente a estrutura institucional da França, como país unitário e fortemente centralizado, suas observações ressaltam fragilidades da instância local de regulação, adaptando-se inclusive à situação brasileira cuja institucionalização federativa, embora tenha suporte constitucional, está apenas se iniciando nos seus desdobramentos administrativos e políticos.

Além disso, no mesmo texto, Veltz afirma que “...a questão grave é saber se as cidades serão capazes de preservar, além de ajustes imediatos, as condições de uso de $\underline{\text { recursos, }}$ eficazes não somente a médio prazo, mas a longo e longuíssimo prazos e de construir contrapesos efetivos às forças centrífugas que induzem atualmente, em diversas escalas, ao crescimento das desigualdades sociais e espaciais."

Durante reunião realizada em Paris, em abril de 2000, pude avaliar conceitos e tendências dos programas de pesquisa com o eng ${ }^{\mathrm{o}}$ Pierre Veltz e pesquisadores da ENPC - École Nationale de Ponts et Chaussées / LATTS - Laboratoire Techniques Territoires et Societés (<http://www.enpc.fr/latts>); na ocasião, a avaliação do conceito recursos disponíveis nas cidades foi feita de forma abrangente, o que incluiria o próprio conjunto de sistemas sócio-técnicos, isto é, as redes de infraestrutura instaladas, juntamente com as suas potencialidades e limitações de operação, manutenção e ampliação no espaço geográfico das cidades.

Desta forma, ao unir os conceitos de infra-estrutura urbana aos de manifestação de poder, sistemas de engenharia e recursos disponíveis, torna-se possível compreender, com maior clareza, os objetivos já citados deste trabalho de pesquisa. A manifestação de poder está na forma de produção do espaço urbano brasileiro que, sistematicamente, adotou uma norma de atuação recorrente: foram privilegiados com sistemas de engenharia apenas alguns sistemas sociais em algumas regiões da cidade, em detrimento de outros grupos sociais em outras regiões, ratificando portanto os processos de concentração de renda tão perversos em nosso País.

Esta situação claramente injusta, todavia guarda em si, dialeticamente, as possibilidades de sua reversão. Bastaria para isso encarar os sistemas de engenharia 
urbana - os sistemas de infra-estrutura urbana - também como recursos, ou seja, como oportunidades para identificação e superação das carências dos sistemas sociais, buscando sua utilização integrada e superação de suas limitações. Desta forma, assegurar-se-iam condições equânimes para suporte de atividades sociais e econômicas em toda a cidade, possibilitando gerar oportunidades equânimes, para todos usufruirem da cidade em sua plenitude.

Este trabalho de pesquisa orienta-se portanto, no sentido da integração e do entendimento geral dos sistemas que, cotidianamente, permitem a vida nas cidades. Foi desenvolvido para equacionar problemas em áreas territoriais definidas, propondo caminhos e soluções para reverter as situações de conflitos entre os sistemas e definindo uma pauta de atividades para uma ampla gama de especialidades, daquilo que poderia, adequadamente, ser entendida como a face urbana da Engenharia, ou seja, a Engenharia Urbana. 


\section{JUSTIFICATIVA}

A gestão dos sistemas e sub-sistemas de infra-estrutura urbana (avenidas, reservatórios de água potável, coleta domiciliar de esgoto, transmissão de energia elétrica em baixa tensão, galerias de drenagem etc) nas cidades brasileiras, dá-se, via de regra, através de diretrizes e ações desarticuladas entre seus diversos setores responsáveis (gestão autárquica) e, mais grave, através de atuações e iniciativas estanques (departamentalizadas), no próprio âmbito interno das organizações administrativas incumbidas das operação, manutenção e ampliação dos sistemas.

Distinguem-se, desde já, várias causas desta situação: nossa tradição hierárquica centralizada e dependente da esfera do Poder Executivo, o caráter monopolista de vários dos serviços ofertados, os estágios tecnológicos diferenciados dos diversos sistemas, a falta de treinamento e atualização dos técnicos operacionais e mantenedores, a fragilidade das instâncias de planejamento urbano e regional, a incipiente organização dos usuários para reivindicações junto às concessionárias, a proposital confusão estabelecida entre as diversas responsabilidades de regulação e provisão dos serviços etc.

Algumas causas todavia mereceriam destaque: está-se situado num País que se urbanizou recentemente, rapidamente e injustamente: de rural para urbano, em cinco décadas seguidas nos meados do século XX e com grande concentração de renda.

Dentro destas severas condições, o conjunto de instituições, às quais estavam afetas as atribuições de prover serviços públicos às cidades, tentou acompanhar o crescimento vertiginoso das demandas, atuando de forma fragmentada, desarticulada e contraditória. A única articulação existente prendia-se à necessidade de solucionar conflitos pelo uso dos espaços superficial, aéreo e subterrâneo das vias para assentamento dos dutos, cabos, canos, postes etc. 
Considerando apenas o aspecto compatibilização das várias redes no espaço das cidades, é notável a precariedade, o conflito e o agravamento das condições dos sistemas de infra-estrutura instalados nas áreas urbanas em todo o país.

Esta situação caótica tem acarretado um processo recente de edição de atos normativos do Poder Público, principalmente municipal, visando ordenar o uso das vias pelos sistemas de infra-estrutura, tendo, como viés principal, a criação de novas fontes de arrecadação tributária, cabendo destacar as seguintes iniciativas de instituições e grupos de interesse neste contexto:

- no Município de São Paulo, o uso do subsolo vem sendo taxado precariamente desde 1999, a partir da edição do Decreto 38.139; o Decreto 40.532 de 08 de maio de 2001 revogou-o, estendendo a cobrança de taxa de uso do subsolo e espaço aéreo a todas as concessionárias; o projeto de lei remetido à Câmara Municipal, para tentar encaminhar politicamente reações adversas de concessionárias, deu origem à Lei 13.614 de 03 de julho de 2003;

- em vários municípios como Rio de Janeiro, Salvador, Porto Alegre, Campinas, Osasco, Votuporanga etc, a cobrança pelo uso do subsolo e espaços aéreos é feita atualmente, o que motivou um posicionamento geral da APM - Associação Paulista de Municípios, criando o "Movimento em Defesa do Espaço Físico e Aéreo das Cidades Brasileiras", objetivando sensibilizar o Congresso Nacional e o Poder Judiciário para a necessidade da cobrança;

- diversos juristas como Celso Bastos (Bastos 2001) e Ives Gandra Martins, posicionam-se pela imprensa contrariamente à cobrança, enquanto o economista Paulo Velloso atribui à Lei de Responsabilidade Fiscal estas iniciativas;

- empresas privadas com serviços de informações e mapeamento de infra-estrutura estão se instalando em São Paulo, com o apoio de agentes privados como a Associação Brasileira de Tecnologia Não-destrutiva (ABRATT), para aplicar no Brasil, a experiência norte-americana de empresa privada, que consolida e vende uma base cartográfica de dados das redes de infra-estrutura, do espaço aéreo e subsolo das cidades. 
Mais recentemente, com a edição da Lei Federal no 10.257 de 10 de julho de 2001, o Estatuto das Cidades, pode-se vislumbrar a possibilidade de mudança radical deste cenário de desarticulação entre sistemas e cidades no País, pelos diversos Instrumentos de Política Urbana ali formulados, destacando-se o referente ao Direito de Superfície (artigos 21 a 24); este instrumento estabelece, mediante prévia anuência do proprietário e com ônus ao usuário, as condições legais para os municípios regulamentarem o espaço físico ocupado pelos sistemas de infraestrutura.

A necessidade de integração dos sistemas de infra-estrutura também está presente nas diretrizes definidas pelo Conselho da Comunidade Européia, em especial a Diretriz 93/38/CEE de 14 de junho de 1993, modificada pela Diretriz 98/4/CEE de 16 de fevereiro de 1998 (Conselho da Comunidade Econômica Européia, 2000). Estas normas definem as exigências para outorga dos mercados de água, energia, transportes e telecomunicações no âmbito dos países membros, considerando que as atividades normalizadas referem-se à disponibilização, operação e suprimento das redes fixas públicas para produção, transporte e distribuição de água potável, eletricidade, gás e calor além de exploração de redes destinadas a fornecer serviços de transportes públicos por trens, ônibus e trólebus, assim como exploração de redes de telecomunicações e fornecimento de serviços relacionados.

Estas diretrizes, que estabelecem basicamente o formato de delegação ou concessão da exploração dos sistemas de infra-estrutura, deflagraram um processo de troca de experiências e aprimoramentos tecnológicos entre os diversos países da Comunidade Européia; são exemplos notáveis deste processo, a disseminação das técnicas de conservação de energia elétrica e água para todos os países indistintamente, elevando rapidamente os níveis de desempenho dos sistemas em diferentes regiões e países europeus. Este processo fica evidenciado pelo crescimento de empresas de conservação que trabalham com os diversos sistemas de infra-estrutura. 
Como justificativa e reafirmação da proposta para uma visão sistêmica e abrangente das redes de infra-estrutura urbana, vale a pena deter-se numa questão fundamental: o que é infra-estrutura e o que são os sistemas de infra-estrutura?

Para tal resposta, selecionou-se uma excelente referência (David Schulz 2000), do Instituto de Tecnologia da Infra-estrutura da Northwestern University / EUA, o qual, depois de traçar um histórico das necessidades humanas desde tempos ancestrais, sugere que infra-estrutura é o conjunto de instalações físicas que move pessoas, bens, mercadorias, águas, resíduos, energia e informação.

Este posicionamento abrangente também está relatado nas conclusões dos seminários de pesquisas integradas de infra-estrutura, promovidos pelas New York University, Polytechnic University e National Science Foundation dos EUA, de 1996 a 1997 e disponíveis no Relatório Final (Priscilla P. Nelson et all 1997). Ressalte-se que já nos trabalhos iniciais de constituição dos diversos grupos de trabalho, são listados diversos sistemas de infra-estrutura, detalhando seus diversos componentes, para balizar os processos subsequentes de discussão. Nas discussões havidas, embora diversos aspectos possam ser destacados, concluiu-se que não obstante as “...descontinuidades existentes entre os diversos aspectos de engenharia dos sistemas de infra-estrutura, consideráveis progressos foram feitos na análise e modelagem de suas interdependências." Um conjunto de campos de pesquisa foram identificados, sendo relatados diversos exemplos tais como a identificação clara das finalidades dos agentes prestadores dos serviços (para fugir de controvérsias), a orientação aos clientes dos serviços (para evitar a responsabilidade difusa entre vários agentes), o gerenciamento e organização de componentes dos sistemas (para buscar complementariedade entre sub-sistemas de serviços distintos) etc.

Para também ratificar esta posição abrangente, o LATTS - Laboratoire Techniques, Territoires et Societés, estabelecido mediante convênio entre a École des Ponts et Chaussées, a Université Paris XII e o CNRS - Céntre Nationale de Recherches Scientifiques, na França, formula objeto de pesquisa direcionado para o estudo de sistemas de infra-estrutura urbana (réseaux techniques). Ao detalhar a abrangência 
destes estudos (LATTS 2004), inicia-se pela discussão das dimensões política, gerencial e aspectos relacionados à amplitude das ações e atores, estendendo o objeto das pesquisas às questões políticas, à dinâmica territorial e à gestão de sistemas de redes de energia, água, esgotos, transportes e telecomunicações.

Finalmente, conforme análise descrita no Capítulo 1 da referência (Grigg 1988), o autor discute o entendimento da APWA - American Public Works Association (EUA) sobre infra-estrutura, que opta por listar 12 categorias, sugerindo que normalmente uma listagem mais reduzida de 6 categorias pudesse ser "mais trabalhável”. Isto posto, Grigg sugere considerar as categorias viária, transportes, energia, hídrica, resíduos sólidos e equipamentos urbanos de grande escala (centros esportivos, parques etc).

Concluindo, o que se depreende é que diversos autores, centros de pesquisa e governos caminham no sentido de considerar infra-estrutura urbana como um conjunto de sistemas conexos, vinculados e interdependentes, que podem então ser planejados, projetados, operados e mantidos de forma integrada.

Esta postura interativa é que permite, segundo a referência (Russel Ackoff 1974), construir soluções permanentes para problemas complexos que, de outra forma, só comportariam soluções reducionistas e portanto obsoletas em curto prazo. 


\section{METODOLOGIAS}

\subsection{Introdução}

As três vertentes metodológicas discutidas a seguir foram organizadas a partir da definição de uma matriz abrangendo todos os sistemas de infra-estrutura, tal como foi destacado nos itens precedentes. Para formulação dos diferentes enfoques metodológicos, deve-se ressaltar sua organização numa seqüência de complexidades crescentes, com integração dos sistemas inicialmente de caráter espacial, evoluindo para a avaliação qualitativa dos serviços prestados e finalmente, procurando caminhos para integrar os sistemas com os dados qualitativos e quantitativos que estiverem disponíveis.

\subsection{A definição de Matriz dos Sistemas de Infra-estrutura Urbana}

Considerando válidas as contribuições de considerar os sistemas de infra-estrutura como interdependentes e considerando a possibilidade de agregá-los em diversos grupos afins, pode-se propor a constituição de 5 grupos a saber:

- grupo de sistemas relacionados ao recurso hídrico, abrangendo sistemas de água, esgoto, drenagem, canais e cursos d'água, reservatórios superficiais e aqüíferos subterrâneos;

- grupo de sistemas relacionados ao viário: rodoviário, ferroviário, aeroviário, hidroviário, cicloviário e viário de pedestres;

- grupo de sistemas relacionados à energia: eletricidade, gás canalizado, gás em botijões, combustíveis e biomassa;

- grupo de sistemas relacionados às telecomunicações: telefone fixo e móvel, teleinformação e teleoperação e

- grupo de sistemas relacionados aos resíduos: sólidos, líquidos e gasosos.

Esta listagem de 5 grupos afins e dos sistemas de infra-estrutura afetos decorre da clara distinção estabelecida entre sistemas e serviços que, respectivamente, correspondem a um conjunto de elementos físicos seqüenciais relacionados entre si 
de modo coerente - os sistemas - , operados e mantidos para disponibilizar benefícios gratuitos ou onerosos aos usuários - os serviços. Desta forma, o mesmo sistema ferroviário pode prestar serviços de transporte de cargas ou de transporte coletivo de passageiros, o mesmo sistema de abastecimento de água pode servir às residências ou às indústrias etc. Inversamente, um mesmo serviço pode ser disponibilizado por diversos sistemas, como por exemplo o transporte de cargas por rodovia ou por hidrovia.

Para detalhar, em cada grupo de sistemas afins, os diversos sistemas e sub-sistemas, faz-se necessário utilizar o conceito de fluxo (que será detalhado no item 4.5.1), explicitado pelos sentidos origem-destino dos diferentes serviços ofertados pelos sub-sistemas e também pela posição adotada pelo observador (ou referencial): caminha-se com o fluxo ou mantém-se estático enquanto o fluxo se processa (Assy 1994).

Ressalte-se, neste ponto, a referência (Zmitrowicz 1997), em Tese de Livre Docência apresentada ao PCC/EPUSP, a qual analisa os processos de estruturação das cidades e a importância assumida pelo estabelecimento de rotinas dos seus habitantes; destaca-se, além do objeto principal da Tese, o item 3.1.3. que conceitua e propõe critérios de análise espaciais para os fluxos em uma estrutura urbana, cabendo transcrever a seguinte afirmação: "...surge-nos assim uma imagem de estrutura urbana constituída de espaços contendo um sem-número de interferências de fluxos que se entrecruzam, e que são passíveis de serem aperfeiçoados através da introdução de novas tecnologias. Na realidade não seria uma única estrutura, e sim um grande número de estruturas interconectadas." De fato, o que se constata são os fluxos e diversas estruturas interconectadas que os viabilizam.

Adotando, além desses aspectos, a denominação geral proposta e citada por Silva (1999), no sentido de estabelecer três categorias para os sub-sistemas - central, arterial e capilar - constituintes de todo e qualquer sistema de infra-estrutura, tem-se uma matriz dos grupos afins, dos sistemas de infra-estrutura urbana e dos diversos componentes arteriais e capilares (vide Quadro 1 - Matriz dos Sistemas de Infra- 
estrutura Urbana), com a proposição de diversos níveis seqüenciais de desagregação dos sistemas assim organizados: os grupos afins, os sistemas e os sub-sistemas centrais, arteriais e capilares. Acrescente-se que esta Matriz deve ser considerada como dependente das características de cada unidade territorial de análise adotada, especialmente quanto à definição dos limites de abrangência dos sub-sistemas.

Esta matriz pode ser interpretada como o conjunto de sistemas de engenharia no conceito do Geógrafo Milton Santos, estando relacionada sempre a uma determinada unidade territorial.

As unidades territoriais de análise (UTAs) também podem ser seqüenciais no sentido das suas abrangências no território: uma ou várias edificações num lote, as várias edificações em lotes contíguos, uma quadra e suas edificações, várias quadras vizinhas, o bairro, a cidade, o município, os municípios contíguos, a região etc.

Para precisar mais claramente os conceitos de central, arterial e capilar, propõe-se aplicar técnicas de definição de características topológicas utilizadas para redes tributárias (em formato de árvore ou arboriforme) e aplicadas para cursos d'água, como descrito na referência (Mosley e McKerchar 1992); no capítulo 8 desta referência, as redes tributárias podem ser classificadas desde seu ponto de ligação com os usuários (ordem 1 ou capilar), incorporando ordens 2 e seguintes (arteriais e centrais), somente a partir de nós que recebam redes de mesma ordem. Como exemplo mais claro de redes tributárias, pode-se citar as redes de esgoto que desde os ramais prediais constituem trechos e conexões, crescendo suas dimensões à medida que mais trechos são conectados. Outro exemplo seriam as redes de drenagem.

Esta regra acima descrita, denominada de Strahler e Shreve na referência citada, permitiria um critério objetivo para definição das categorias capilar, arterial e central dos sistemas e sub-sistemas numa unidade territorial de análise, considerando o número de ordem das redes tributárias. Para tornar esta regra aplicável às redes fechadas (como normalmente são implantadas redes de água, de ruas etc), sugere-se 
QUADRO 01

MATRIZ DOS SISTEMAS DE INFRA-ESTRUTURA URBANA

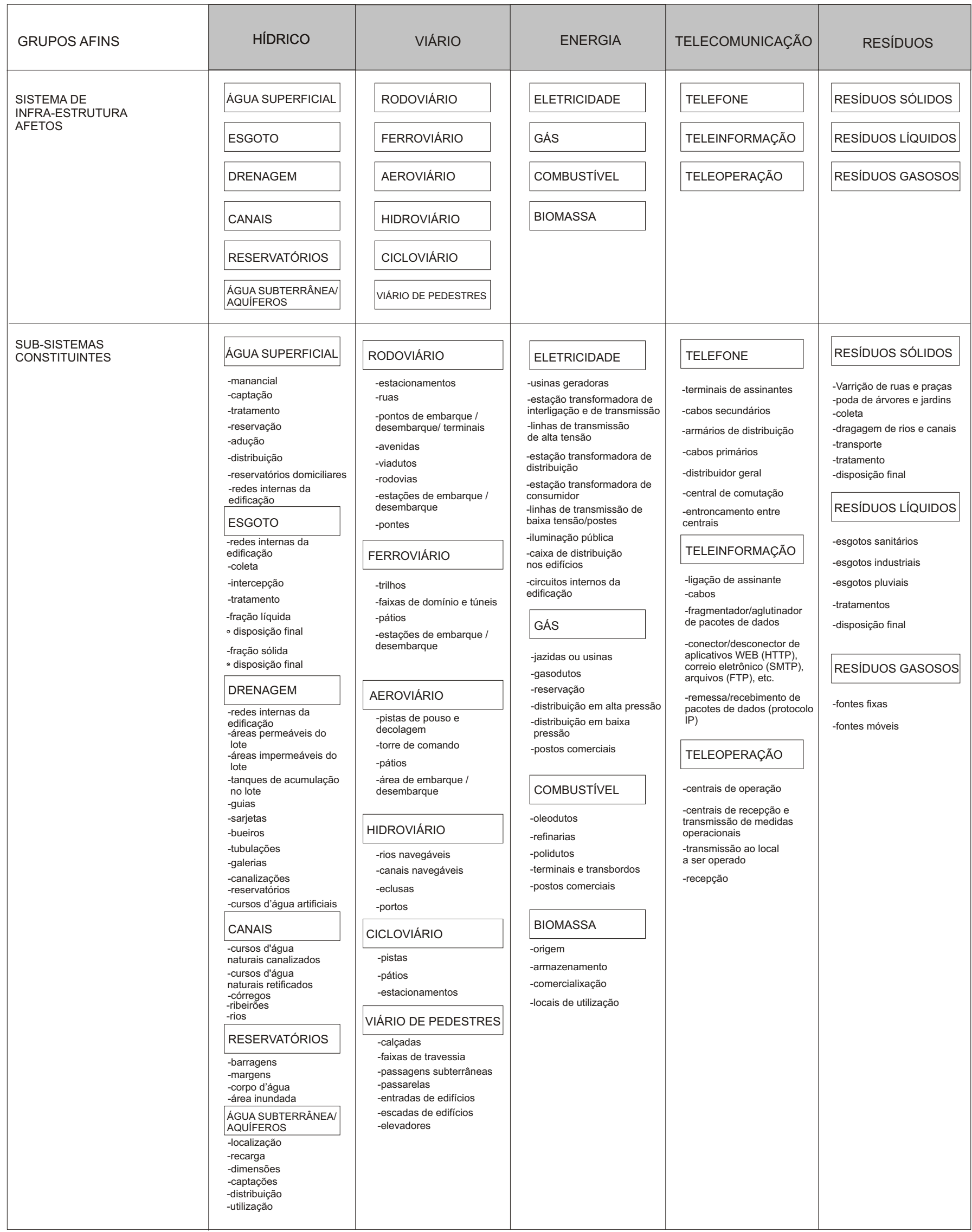


um critério de segmentação para considerá-las tributárias (ou arboriformes), mediante um corte virtual das malhas em trechos onde os fluxos sejam relativamente pequenos, e se desenvolvam num sentido e no oposto, caracterizando situações limites, que são freqüentes nos sub-sistemas capilares. Como exemplo destes casos, além das redes de água e de ruas, pode-se citar as redes de energia elétrica que nos seus trechos capilares podem ser virtualmente segmentadas transformando-se em redes tributárias.

Uma vez definida a Matriz dos Sistemas para uma determinada unidade territorial de análise, cumpre-se um primeiro objetivo da Tese relativo à sistematização dos sistemas.

Concluída esta parte e com base nesta visão matricial sistêmica, torna-se possível formular diversas metodologias de integração da gestão dos sistemas de infraestrutura, em níveis crescentes de complexidade, como exposto a seguir.

\subsection{A Opção Metodológica 1}

Esta opção metodológica baseia-se exclusivamente na constatação acerca da existência ou não existência dos sistemas e sub-sistemas e das suas dimensões e localizações numa determinada unidade territorial a ser analisada (ver Desenho 1); ou seja, desde um lote com edificação até uma escala regional da UTA, a representação do resultado (que poderá ser cartográfica), deverá ter três atributos associados: existência, dimensão e localização.

Neste caso, a possibilidade de gestão integrada dos sistemas de infra-estrutura restringe-se à definição das suas posições relativas, visando quantificar os espaços ocupados e delimitar os espaços disponíveis.

Trata-se então de criar cadastros espacializados dos sistemas, atualizáveis e disponibilizáveis para qualquer plano, programa ou projeto de ampliação de um sistema ou sub-sistema em particular. Estes cadastros normalmente inadministráveis 
na situações tradicionais, ganham grande viabilidade a partir dos cadastros de informações georeferenciadas digitais, atualmente bastante difundidos.

\subsection{A Opção Metodológica 2}

Numa determinada unidade territorial, esta opção permite um grau de informação adicional em relação à Opção Metodológica 1, ao propor a qualificação dos sistemas e sub-sistemas existentes segundo níveis de desempenho (vide Desenho 2). Estes critérios podem ser subjetivos e arbitrários, variando, por exemplo, segundo os graus ótimo, bom, razoável e péssimo ou podem ser avaliados objetivamente, mediante discretização de qualquer parâmetro operacional de desempenho do serviços providos (regularidade de atendimento, por exemplo), para então definir os intervalos qualitativos de cada sistema e/ou sub-sistema; neste caso, a representação do resultado poderá ser cartográfica, com quatro atributos: existência, dimensão, localização e qualidade de desempenho.

Nesta opção, a gestão integrada dos sistemas será possível quanto ao aspecto desempenho, revelando-se quais deles estão deficitários ou superavitários em relação aos demais, o que permite identificar quais os sistemas que necessitam melhorias. Desta forma, podem ser identificados pelo gestor urbano daquela UTA, quais os sistemas que se constituem em óbices a um eventual aumento localizado de demanda, abrindo-se a possibilidade de dirigir-se à entidade responsável e/ou concessionária do sistema, com reivindicações relativas a heterogeneidade das ofertas de serviços locais.

\subsection{A Opção Metodológica 3}

A terceira opção metodológica para equacionamento do problema integração de sistemas de infra-estrutura urbana reside na explicitação e consideração do conceito de fluxo: está-se diante da cidade em movimento, onde a população residente e/ou visitante numa determinada unidade territorial de análise circula, produzindo e/ou 
METODOLOGIA 1

\begin{tabular}{|c|}
\hline $\begin{array}{l}\text { DEFINIÇÃO DA } \\
\text { U.T.A (UNIDADE } \\
\text { TERRITORIAL } \\
\text { DE ANÁLISE) }\end{array}$ \\
\hline Lote com edificação \\
\hline $\begin{array}{l}\text { Lotes contíuguos } \\
\text { com edificações }\end{array}$ \\
\hline Quadra urbana \\
\hline Quadras vizinhas \\
\hline Bairro \\
\hline Bairros contíguos \\
\hline Cidade \\
\hline Municípios \\
\hline $\begin{array}{l}\text { Municípios } \\
\text { contíguos }\end{array}$ \\
\hline Região \\
\hline
\end{tabular}

MATRIZ DOS SISTEMAS DE INFRA-ESTRUTURA URBANA

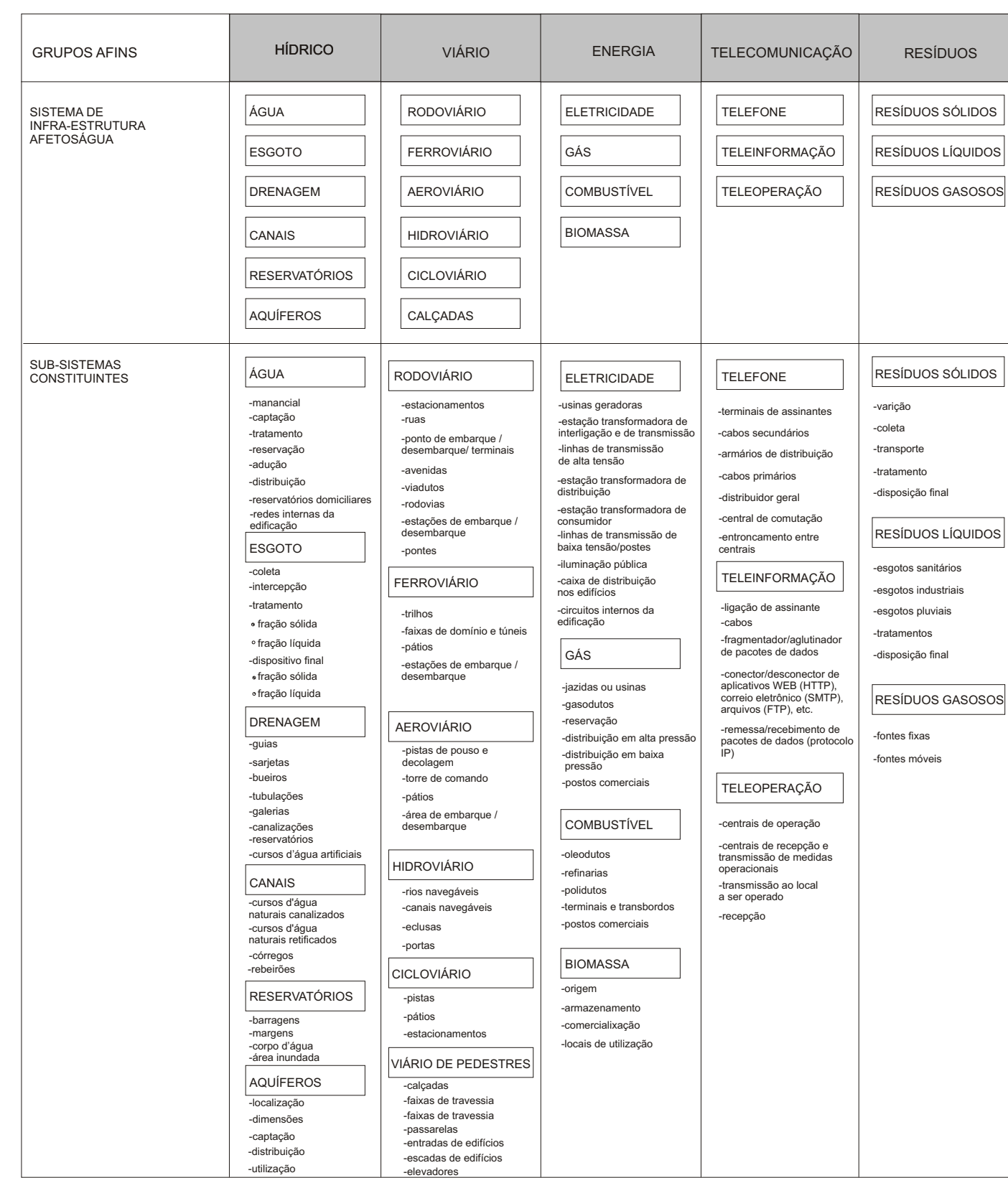

MATRIZ DOS SISTEMAS DE INFRA-ESTRUTURA NA U.T.A.

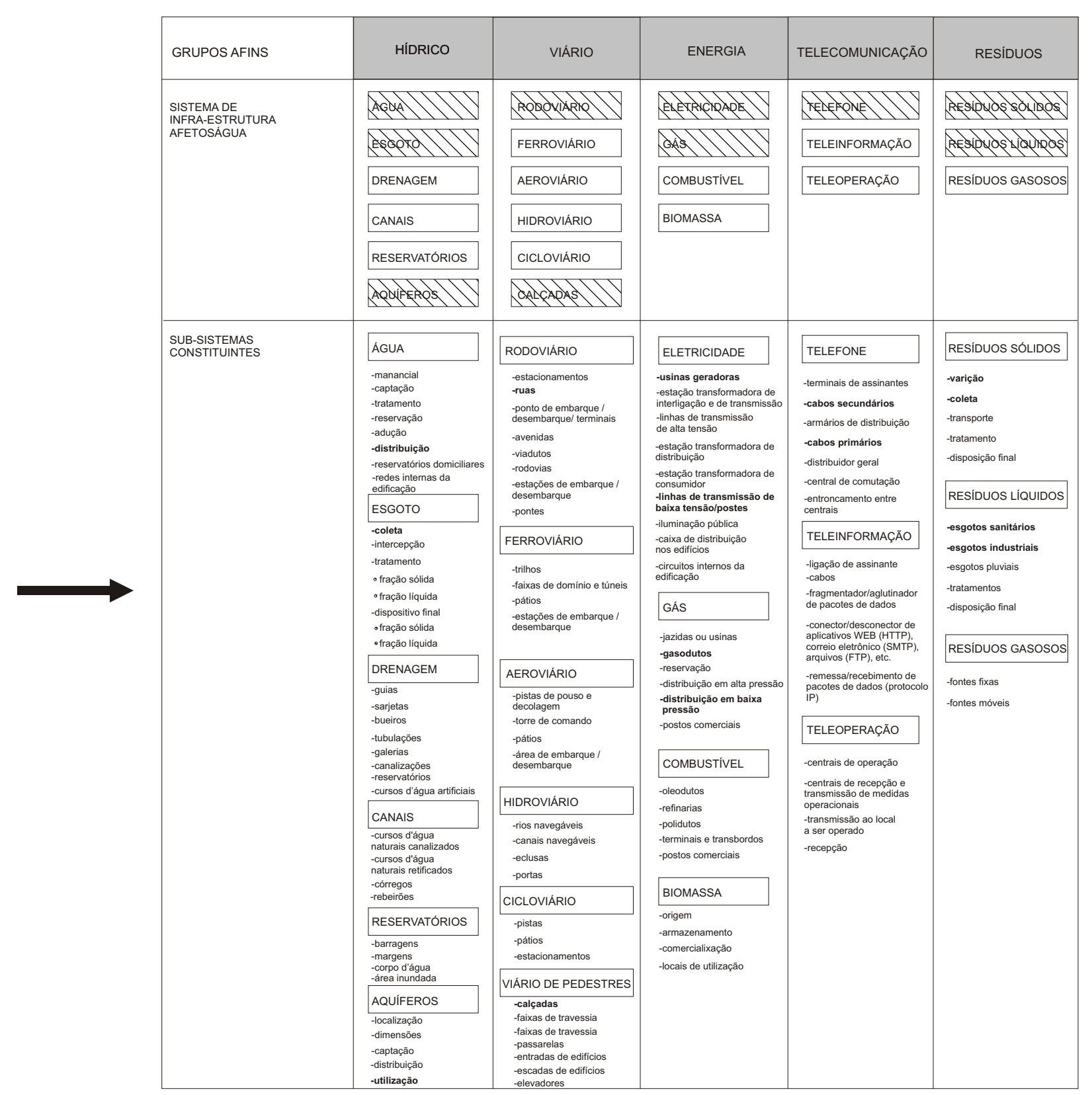


transportando bens e mercadorias, utilizando-se dos sistemas e dependendo deles para que estas atividades sejam possíveis.

\subsubsection{O Conceito de Fluxo}

Fluxo pode ser definido como o estado de movimento de indivíduos e/ou matéria, em relação à uma base de referência, subordinando-se às condições impostas pelos ambientes naturais e ambientes construídos, o qual é estabelecido pela utilização total ou parcial das capacidades próprias dos indivíduos e/ou disponíveis em componentes dos diversos equipamentos dos diversos sistemas ali presentes.

Como exemplo elucidativo, o ciclo hidrológico pode ser entendido como o fluxo da água em seus diversos estados, movimentando-se em relação a um determinado espaço geográfico, para onde a água aflui e/ou escoa e/ou se armazena; em bacias hidrográficas, o fluxo da água pode ser compreendido como o volume que aflui na forma de chuva, da contribuição de aqüíferos subterrâneos, de escoamentos superficiais, de reversões etc; o volume que escoa na forma de evaporação, transpiração, escoamentos superficiais e subterrâneos etc e o volume que permanece ali retido como reservatórios superficiais ou aqüíferos subterrâneos. Para que este movimento se realize (ou para que este fluxo se estabeleça), é necessário uma fonte de energia - no caso o Sol - que possibilite a realização deste trabalho de deslocamento de volumes de água até posições da bacia hidrográfica que permitam o escoamento por gravidade.

Deste exemplo, fica claro que a existência e o estudo dos fluxos pressupõem respectivamente a disponibilidade de energia como viabilizadora do movimento e a definição da unidade territorial de análise.

Buscando transpor este raciocínio para uma determinada porção territorial das cidades, tem-se que inicialmente considerar seus limites precisos ou seja a delimitação geográfica da UTA: se a unidade territorial de análise é o lote e sua edificação, as edificações em lotes contíguos, a quadra, algumas quadras vizinhas, o 


\section{METODOLOGIA 2}

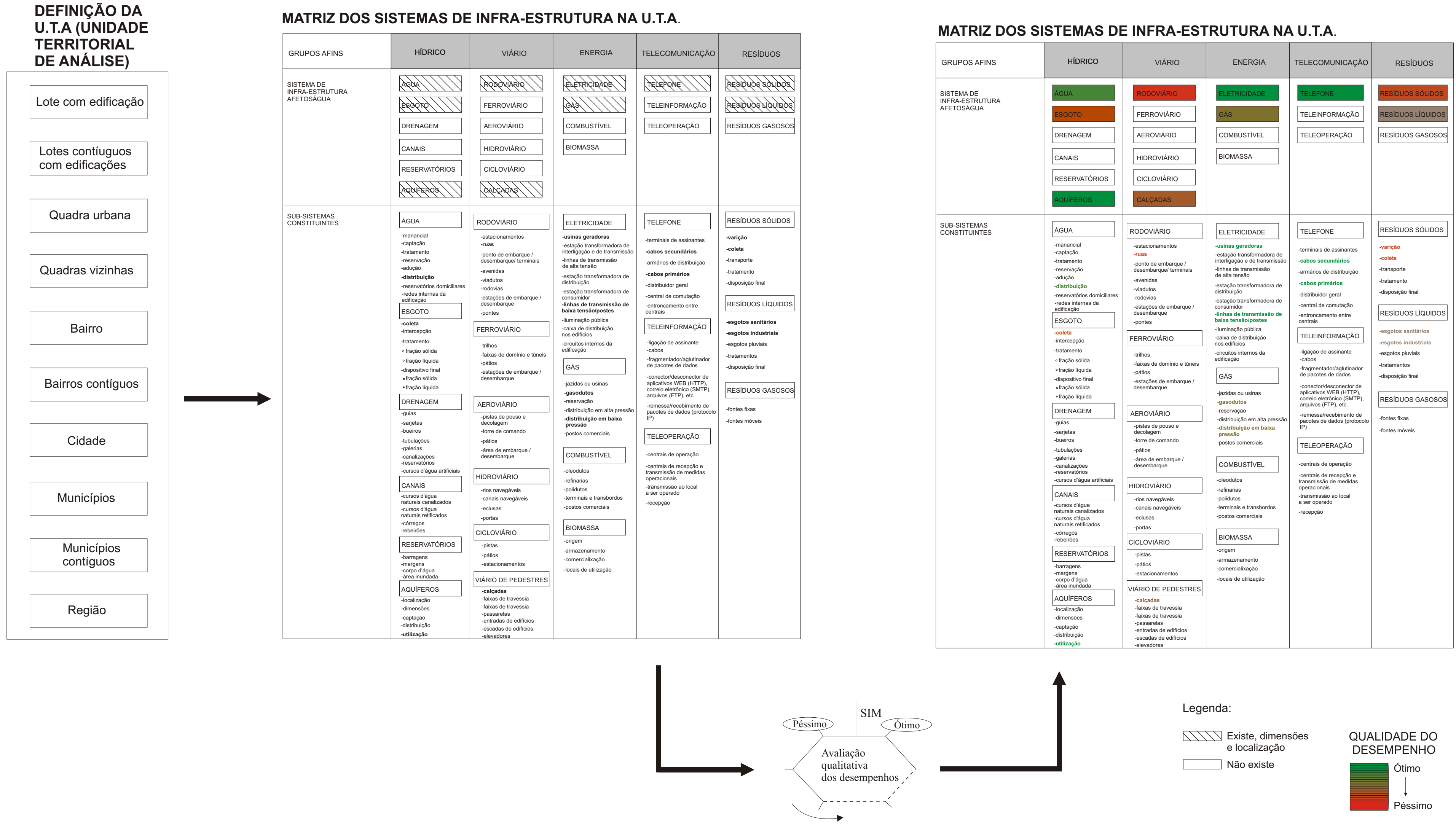


bairro, os bairros contíguos, toda a cidade, o município, os municípios contíguos, a região etc. Numa porção territorial definida, deve-se supor, inicialmente, que fontes de energia estão disponibilizadas, permitindo desta forma que um conjunto de usuários (U) acesse e/ou permaneça e/ou se retire daquela área, caracterizando um conjunto variável no tempo $(t)$ ou seja $U=U(t)$. Supondo que as fontes de energia estejam disponibilizadas também para todos os sistemas de infra-estrutura, isto significa que os diversos componentes desses sistemas passam a ter condições de garantir oferta dos serviços correspondentes, no limite de suas capacidades instaladas, para suprimento da demanda existente de cada um dos serviços, ao conjunto de usuários $\mathrm{U}(\mathrm{t})$.

Nesta seqüência de raciocínio, há que distinguir, nos diversos sistemas de infraestrutura, as diferenças intrínsecas entre eles e, se possível, desenvolver análises de eventuais complementariedades. Neste aspecto é que, por exemplo, as propriedades físicas dos sistemas de telecomunicações e de distribuição de energia elétrica podem cumprir, além das funções precípuas de prover quase instantaneamente comunicação, telecomando, força motriz, aquecimento, iluminação etc, uma outra função de grande relevância: identificar e quantificar, no instante $t$, qual é o conjunto de usuários $U(t)$ presentes naquela unidade territorial de análise considerada.

As características de resposta dos sistemas elétricos às solicitações dos usuários está descrita na referência (Monticelli e Garcia 2000), que afirma, em relação aos sistemas locais de distribuição de energia elétrica, que o tempo de resposta à solicitação de um usuário é da ordem de $10^{-3}$ segundos, alcançando o valor de 1 segundo para o sistema gerador-turbina. O sistema de distribuição de energia elétrica da unidade territorial de análise pode, com isso, cumprir uma função interativa de explicitar para os outros sistemas de infra-estrutura com comportamento inercial (como o abastecimento de água por exemplo), quantos usuários estão presentes naquela porção territorial definida, os quais poderão utilizar-se das instalações hidráulicas e sanitárias das edificações, solicitando conseqüentemente os subsistemas de distribuição, adução, reservação, tratamento etc. 
Isto significa que, em se adotando a denominação geral de sub-sistemas central, arterial e capilar proposta por Rothenberg, pode-se afirmar que enquanto em energia elétrica os três sub-sistemas respondem, quase simultaneamente, ao acionamento das instalações elétricas domiciliares, no caso da água, os três sub-sistemas tem tempos de respostas, que dependem da celeridade de propagação das solicitações advindas das instalações hidráulicas e sanitárias das edificações e também de características das redes como diâmetros, materiais, articulações dos trechos, vazões transportadas etc.

Para melhor ilustrar esta concepção metodológica, pode-se esquematicamente descrever um encadeamento de eventos diários sucessivos, dentro do espaço territorial de análise definido:

Evento 1 (inicial): com a disponibilidade de eletricidade e combustíveis, os serviços de transportes solicitam os sistemas viários e movimentam passageiros de suas origens para seus destinos;

Evento 2: os passageiros em seus destinos tornam-se usuários potenciais dos sistemas de energia elétrica, água, esgotos, resíduos etc, tendo desonerado os mesmos sistemas na origem de suas viagens;

Evento 3: os usuários, em seus locais de destino ou fora dos seus locais de origem, são identificados, em poucos segundos, pelo sistema distribuidor de energia elétrica (e o respectivo Centro de Controle Operacional - $\mathrm{CCO}$ );

Evento 4: os usuários dos sistemas de água, esgotos e resíduos em seus locais de destino, são "percebidos" pelos sistemas e Centros de Controle Operacional (CCOs) respectivos, apenas decorrido um intervalo de tempo (da ordem de grandeza de minutos ou horas), que depende de características do sistema e da solicitação havida; Evento 5: os usuários ao final da jornada diária, já como passageiros, voltam aos seus pontos de origem, desonerando os sistemas de energia elétrica, água, esgotos, resíduos etc e solicitando estes mesmos sistemas ao chegarem, sendo "percebidos" quase instantaneamente pelo CCO do sistema de energia elétrica;

Evento 6: os usuários de água, esgotos e resíduos em seus locais de origem são percebidos decorrido um intervalo de tempo, pelos centros de controle operacional respectivos e 
Evento 7 (final): as solicitações dos sistemas são gradativamente diminuídas, até recomeçar um novo ciclo.

Ressalte-se que o comportamento de cada sistema em ciclos (que podem ser diários, $\underline{\text { semanais, }} \underline{\text { sazonais, }}$ anuais etc) está sujeito a diversos fatores aleatórios e/ou determinísticos, que deverão ser avaliados e poderão ser quantificados em existindo base de dados adequada.

Neste ponto - base de dados consistente e disponível - é que se manifestam dois caminhos metodológicos distintos para esta opção 3: o primeiro (3/1) é promover a análise integrada dos sistemas, utilizando os métodos ou modelos operacionais disponíveis das concessionárias e operadoras e/ou propondo outros, procurando estabelecer correlações matemáticas, utilizando-se de técnicas disponíveis de modelos de previsão, de simulação, seqüências de apoio às decisões etc; o segundo caminho (3/2) consiste em realizar a análise integrada dos sistemas procurando o nexo, a interdependência e a pertinência entre eles, utilizando o imenso potencial de análise da Lógica Paraconsistente, como uma das Lógicas Não Clássicas, a partir do pressuposto básico que as informações operacionais estão via de regra incompletas e indisponíveis, e que a gestão integrada dos sistemas necessita análises muito complexas, justificando que se utilize, ao máximo, os fatores subjetivos acumulados com a experiência operacional em cada Centro de Controle Operacional (CCO) existente.

\subsubsection{O Caminho Metodológico 3/1}

Em relação ao primeiro caminho metodológico (opção 3/1), ou seja, apoiar-se sobre modelos/métodos operacionais existentes e construir um grande modelo de correlação associando-os (vide Desenho 3), deve-se ressaltar sua viabilidade técnica e seu custo muito elevado, tornando-o desta forma pouco operacional, ou seja, de aplicação eventual e não rotineira. 
METODOLOGIA 3 / 1

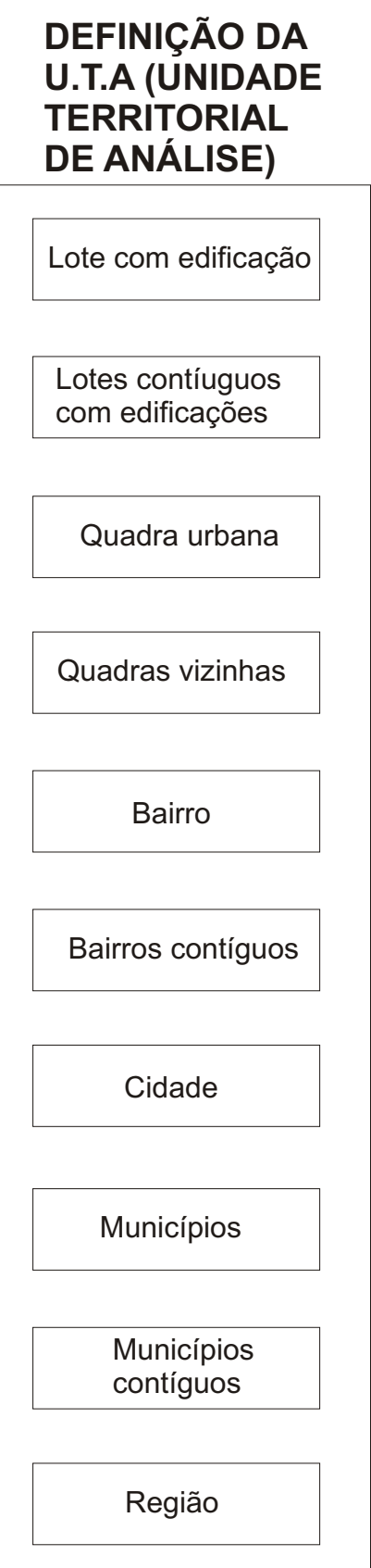

\section{MATRIZ DOS SISTEMAS DE INFRA-ESTRUTURA NA U.T.A.}

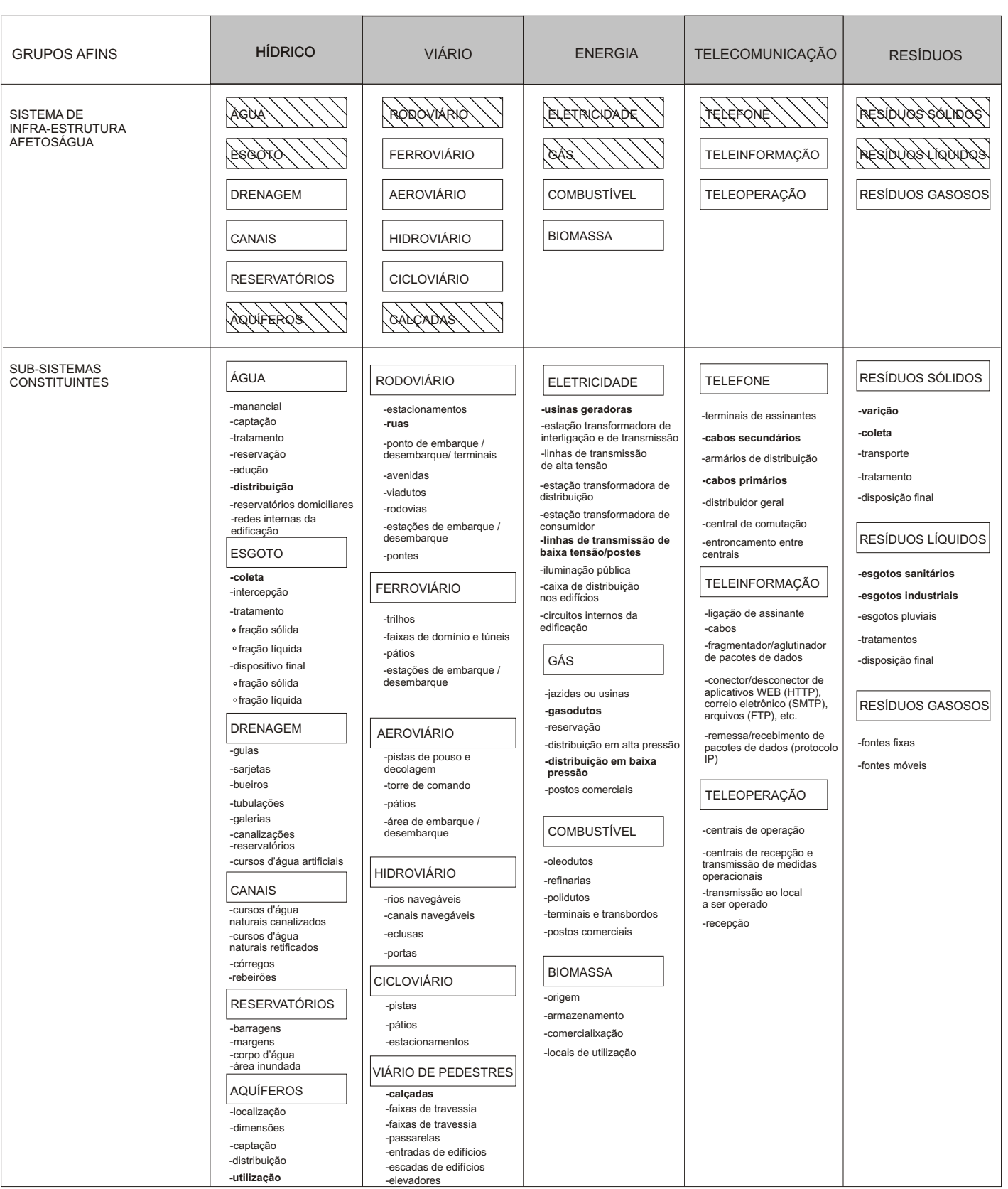

\section{MATRIZ DOS SISTEMAS DE INFRA-ESTRUTURA NA U.T.A.}

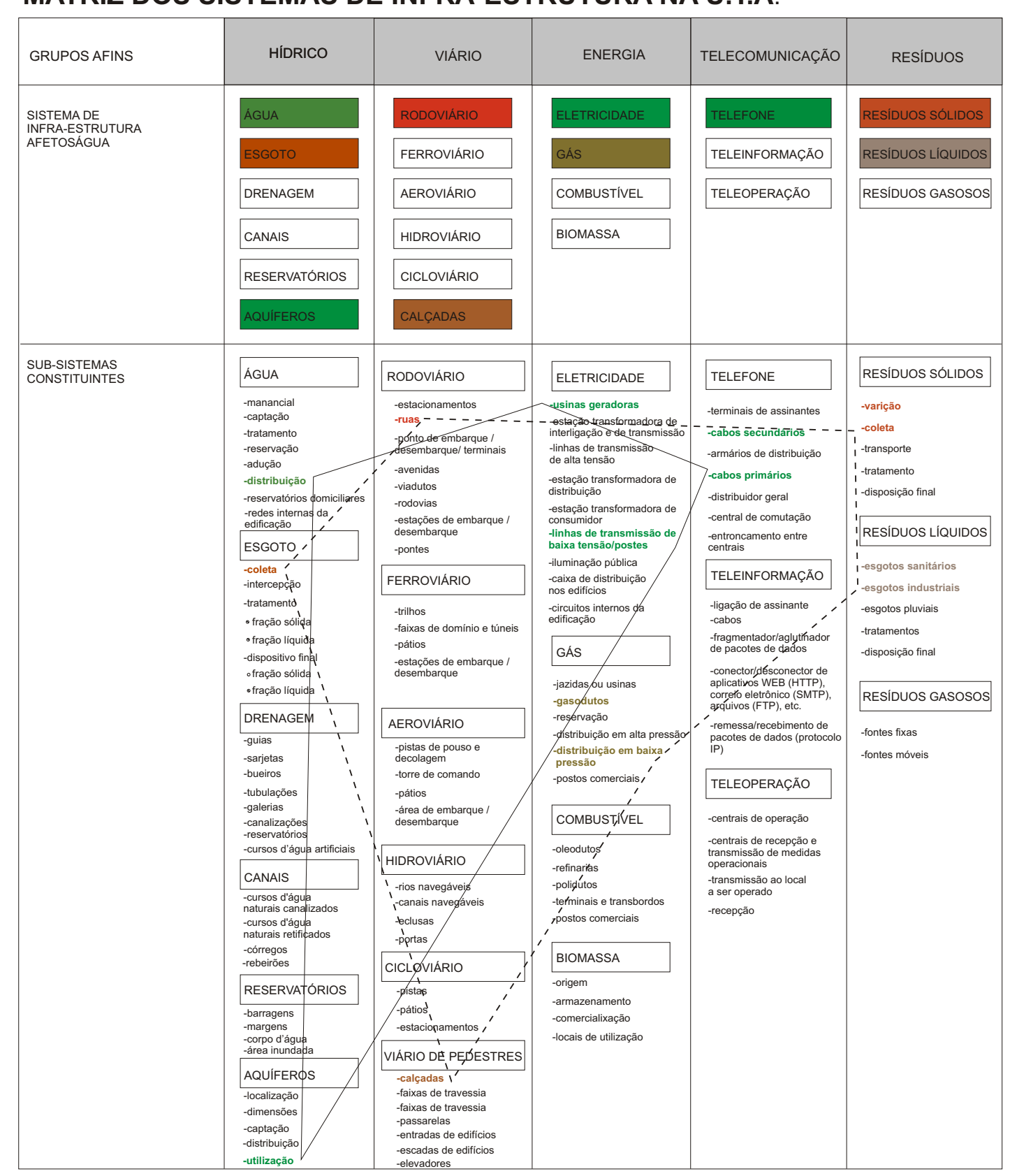

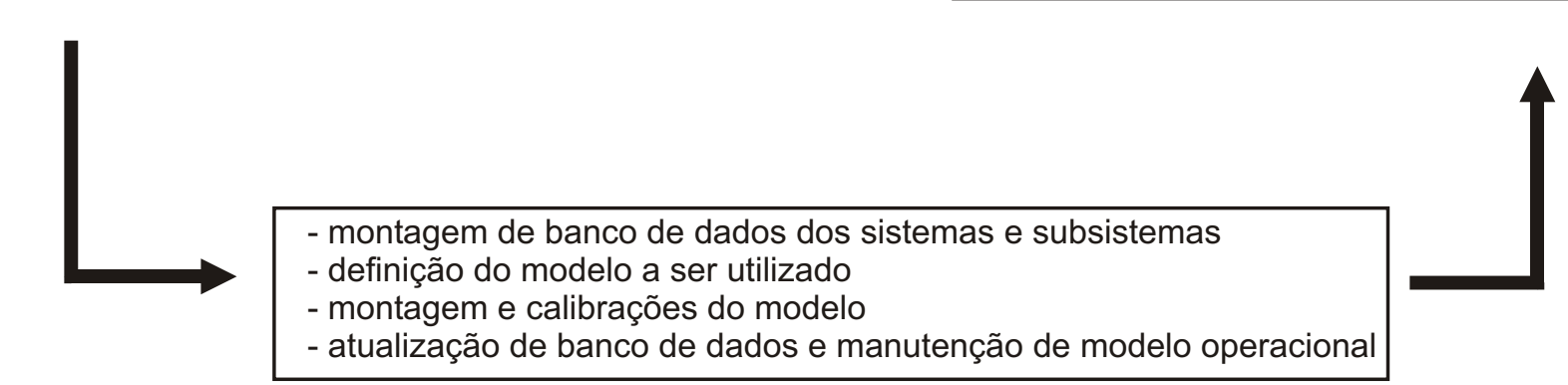

Legenda:

$\$ 1117$
Existe, dimensões
e localização $\square$ Não existe MODELO 1 
A viabilidade técnica deste grande modelo pode ser entendida considerando que o conjunto de usuários (U) presentes numa unidade territorial de análise(UTA), é variável no tempo $(\mathrm{t})$, podendo ser caracterizado como demandas potenciais de serviços de transportes, energia elétrica, água, esgoto etc , os quais estão sendo supridos pelos sistemas modais viários (V), sistema de energia elétrica (E), sistema de água (A), sistema de esgoto (ES) etc, onde também se verificariam as relações dependentes do tempo (t) e por esta razão, tornando-se inter-relacionáveis. Daí é que se torna possível construir correlações do tipo $\mathrm{V}[\mathrm{U}(\mathrm{t})]$ como função de $\mathrm{E}[\mathrm{U}(\mathrm{t})]$, de $\mathrm{A}[\mathrm{U}(\mathrm{t})]$, de $\mathrm{ES}[\mathrm{U}(\mathrm{t})]$ etc.

Ressalte-se que uma medida da viabilidade técnica deste caminho metodológico pode ser feita, estimando-se o grau de confiabilidade da correlação. Na excelente referência (Tavares 1996), são discutidos diversos métodos para construir modelos de previsão, de médias móveis, de simulação, determinísticos, estocásticos, de apoio à decisão etc, que podem ser adaptados à tarefa de estabelecer relações entre sistemas de infra-estrutura urbana na forma referida, ou seja, relacionando-os com a variável tempo, da qual dependerá o ritmo das solicitações de cada sistema. Também merecem destaque a referência (Cohen 1995), que realiza uma consolidação de diversas experiências de utilização de modelos na França, facilitada por ser, o próprio autor, responsável pelo desenvolvimento e aplicação de modelos matemáticos em sistemas de água e de calefação e as referências (Dupuy e Tarr 1984), (Dupuy e Tarr 1988) e (Dupuy 1991) que detalham de forma circunstanciada toda a profunda elaboração havida, principalmente na França, objetivando lançar as bases de um "urbanismo dos sistemas de infra-estrutura".

\subsubsection{O Caminho Metodológico 3/2}

No segundo caminho metodológico (opção 3/2), ou seja, utilização da Lógica Paraconsistente, reconhece-se a priori que a experiência de gerentes da ampliação e de operação dos sistemas permite, quase sempre, incorporar condicionantes de realidade diversificados, os quais, pelas suas características de subjetividade, multiplicidade, dificuldade de mensuração etc, não são considerados em modelos 
matemáticos operacionais. Para diversos operadores de sistemas e sub-sistemas, algumas variáveis de decisão podem estar fora do âmbito dos modelos operacionais adotados nos seus respectivos CCOs, como realmente ocorre em dias quentes, dias chuvosos, bairros recentes, bairros consolidados, áreas industriais, feriados prolongados, fins de semana etc, restando-lhes, nestes casos, a alternativa de considerá-las subjetivamente, para garantir níveis de desempenho adequados nos respectivos sistemas.

Esta segunda opção metodológica baseia-se na constatação de que a opção (3/1) não resolve aspectos contraditórios, indefinições, ambigüidades, dados vagos ou de pouca clareza etc dos sistemas. Ou seja, ao apoiar-se na Lógica Clássica, a opção (3/1) tem limitações na interpretação e atuação sobre algumas situações reais.

A incorporação de conceitos da Lógica Paraconsistente, e especificamente a Lógica Paraconsistente Anotada, permite considerar as contradições, as indefinições e a não disponibilidade de informações, como um dado inicial inescapável da realidade cotidiana das cidades, e que influem decisivamente no desempenho dos sistemas de infra-estrutura.

Nos centros de controle operacional (CCOs) existentes nas cidades, pode residir a perspectiva de solução da integração entre os sistemas, pois que os operadores com os seus sistemas já atuam com a cidade real, com os hábitos dos seus habitantes já conhecidos e portanto em condições de aprimorar os modelos operacionais, moldando-os ao comportamento cotidiano e real da cidade (vide Desenho 4).

No caso por exemplo do sistema de abastecimento de água, sub-sistema, redes domiciliares, os operadores do $\mathrm{CCO}$ e os responsáveis pelas manobras nas redes, já incorporam ao seu cotidiano, informações sobre uso de edificações (comércio, escritórios, hospitais etc), sobre a renda predominante dos usuários, sobre bairros consolidados ou em processo de consolidação etc. No caso de um sistema rodoviário em cidades, os serviços de ônibus que o utilizam cotidianamente podem ter seus níveis de desempenho subjetivamente avaliados, com auxílio dos operadores dos 
CCOs e dos condutores dos equipamentos (os motoristas), podendo com isso acrescentar diversas informações adicionais naquela Unidade Territorial de Análise, relativas ao trecho do viário percorrido, horário do dia, presença de equipamentos sociais com demandas concentradas etc.

O que se depreende então, é que a manipulação de grandes quantidades de informações, de naturezas diversas, relativas aos diversos sistemas de infra-estrutura urbana, freqüentemente leva a dados incertos, vagos ou até mesmo conflitantes, além de falta crônica de informações mais relevantes. Além disso, as técnicas usualmente adotadas para o tratamento de tais dados, citadas ao longo da discussão da metodologia $3 / 1$, baseiam-se normalmente na Lógica Clássica, que por ter uma semântica binária, mostra-se pouco adequada para o processamento e manipulação de dados dessemelhantes e/ou com as características de incerteza, indefinições etc já referidas.

A Lógica dos Sistemas Nebulosos (ou Lógica Fuzzy) supriu com enorme êxito muitas dessas deficiências, mostrando sua extrema fecundidade na modelagem de sistemas complexos de Engenharia, com inúmeras aplicações. Conforme afirma a referência (Cox 1992), uma regra operacional nebulosa (ou "fuzzy") poderia substituir com vantagens várias regras convencionais.

Este caminho da busca de "fatores subjetivos" e seu tratamento segundo a Lógica Nebulosa, também está explicitado em disciplinas ministradas na EPUSP/PCC (Yee 1999); nesta referência, merecem destaque as aulas Medida Nebulosa e Agrupamento Nebuloso, que estabelecem métodos específicos para criação de uma escala subjetiva de avaliação de diversas grandezas e sua correlação posterior, a partir da identificação de graus de pertinência.

Para concretizar o resgate das informações subjetivas e com isso viabilizar uma metodologia correspondente, propõe-se a adoção de uma ferramenta formal, apoiada no domínio da Lógica Paraconsistente. Os conceitos utilizados baseiam-se numa nova classe de lógicas pesquisadas recentemente, as Lógicas Paraconsistentes 
METODOLOGIA 3 / 2

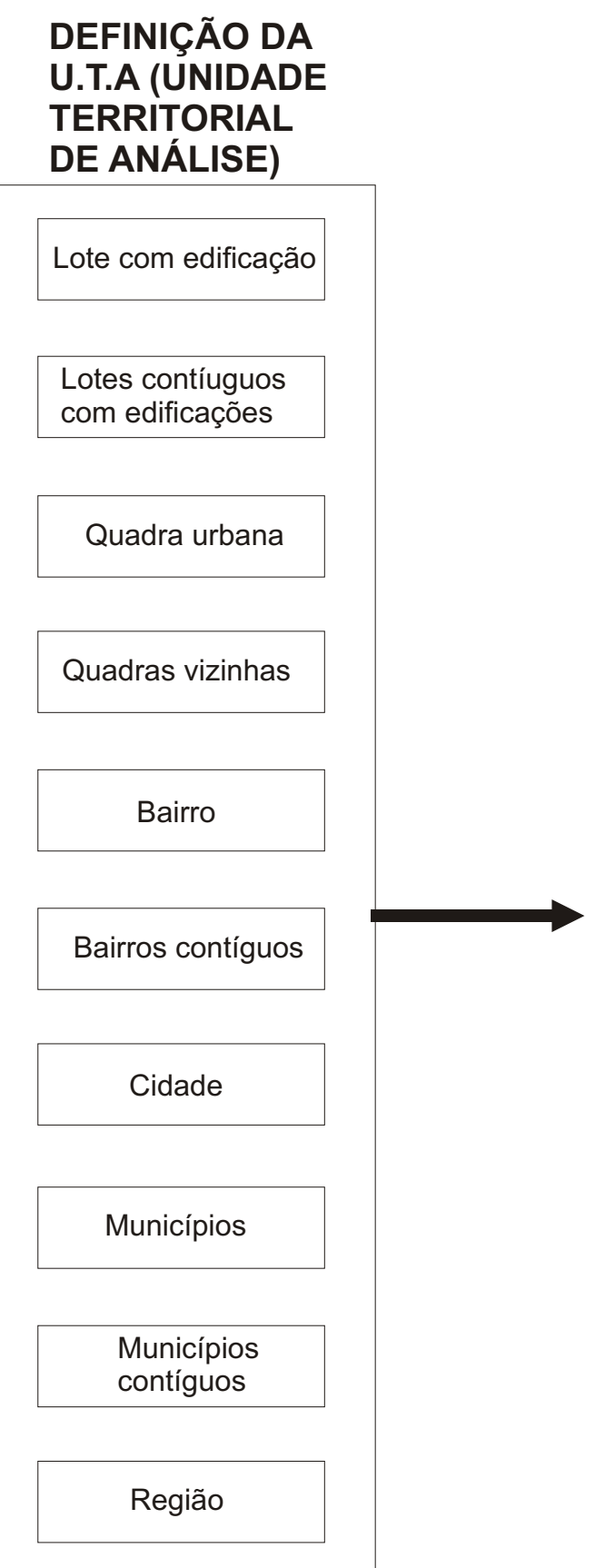

MATRIZ DOS SISTEMAS DE INFRA-ESTRUTURA NA U.T.A.

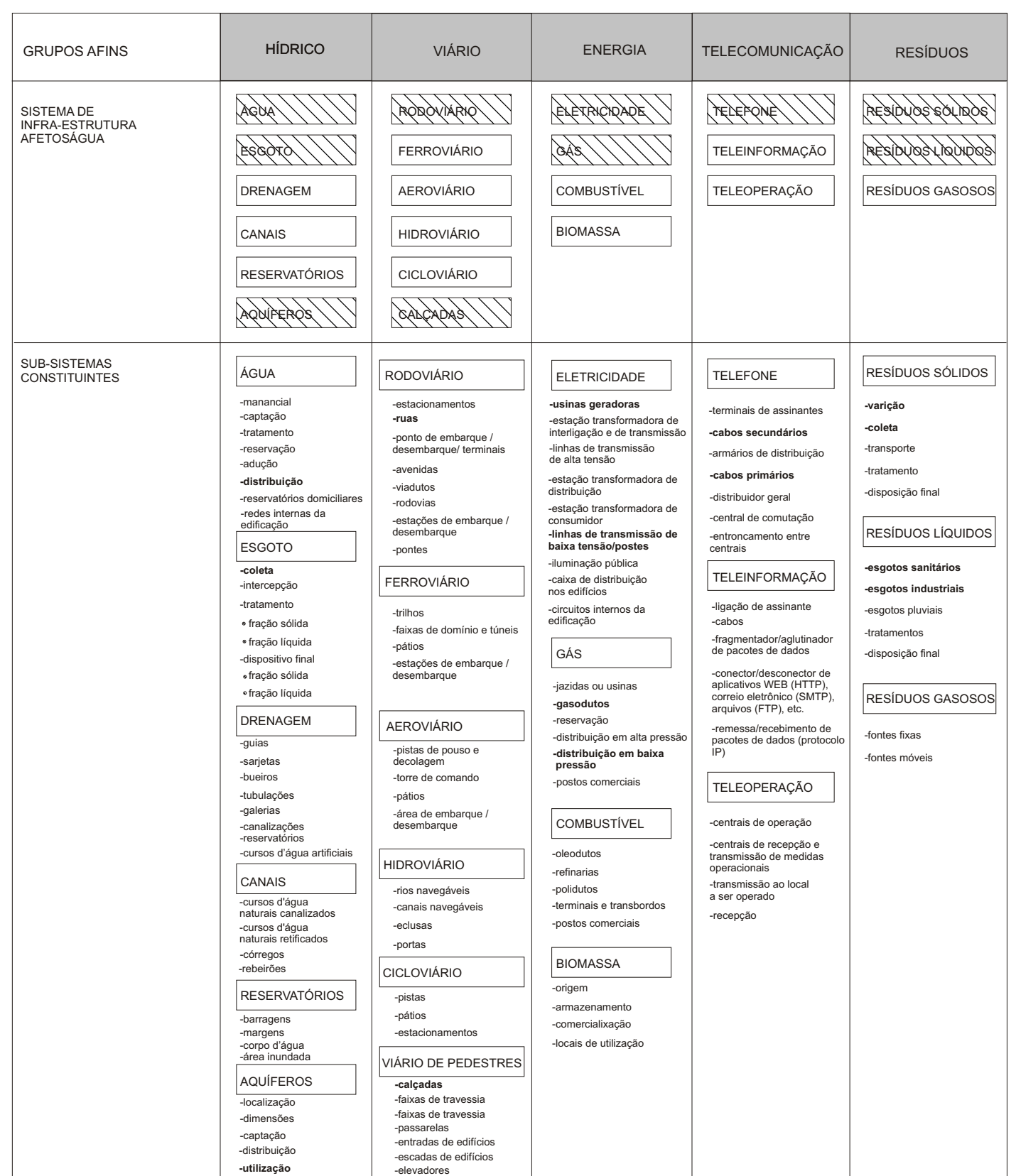

MATRIZ DOS SISTEMAS DE INFRA-ESTRUTURA NA U.T.A

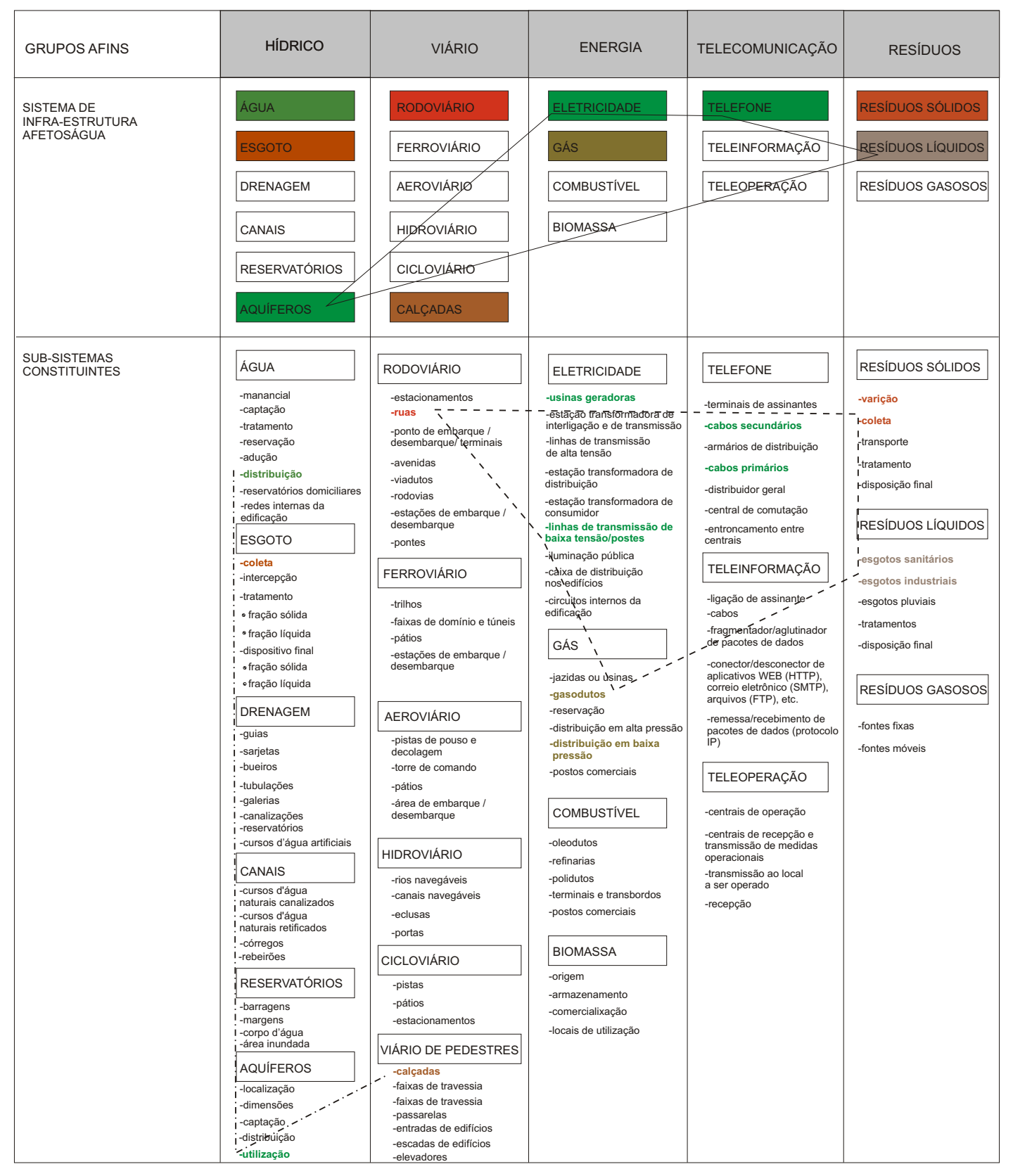

$\longrightarrow$\begin{tabular}{|l|l|}
\hline & $\begin{array}{l}\text { - formular proposição P de integração de sistemas } \\
\text { - definir especialistas e coletar graus de crença e de descrença } \\
\text { - palicar algoritmo para-analisador } \\
\text { - definir viabilidade da proposição e ações para implementá-la }\end{array}$ \\
\hline
\end{tabular}

MIIV Existe, dimensões e localização 
Anotadas (LPA) e a adoção desta proposta baseia-se fundamentalmente em duas razões: primeiro, ela permite tratar todos os dados e conceitos adequadamente, abarcando também as contradições, inconsistências e indeterminações; em segundo, ela possui sintaxe e semântica bem definidas, o que a torna manipulável computacionalmente, através de um algoritmo denominado Para-analisador, que deverá ser utilizado em nosso trabalho.

A seguir, é feita uma explanação do método da LPA que serve de base para uma proposta de integração de sistemas de infra-estrutura urbana.

\subsubsection{A Lógica Paraconsistente Anotada com graus de crença (evidência favorável) e descrença (evidência contrária)}

As lógicas paraconsistentes anotadas são uma família de lógicas não-clássicas inicialmente empregadas em programação lógica (Subrahmanian 1987); posteriormente (Blair \& Subrahmanian 1987) construíram a Teoria Geral da Programação Anotada e obtiveram aplicações em bases de dados que contém contradições.

Os primeiros estudos sobre os fundamentos da Lógica Paraconsistente Anotada foram efetuados em (Da Costa, Vago e Subrahmanian 1991), (Da Costa, Abe e Subrahmanian 1991) e (Abe 1992). Em (Abe 1992) estudou-se a "lógica de predicados, teoria de modelos, teoria anotada de conjuntos e alguns sistemas modais", estabelecendo um estudo sistemático dos fundamentos das lógicas anotadas apontadas em trabalhos anteriores. Outras aplicações dos sistemas anotados foram iniciados por Abe em 1993 e juntamente com discípulos implementou-se a linguagem de programação paraconsistente Paralog.

Tais idéias foram aplicadas na construção de um protótipo de equipamento baseado na Lógica Paraconsistente Anotada, que integra vários sistemas computacionais (planejadores, base de dados, sistemas de visão etc) (Prado 1996) e de representação 
de conhecimento por "Frames", permitindo representar inconsistências e exceções (Ávila 1996).

Também em (Da Silva Filho 1999), (Abe e Da Silva Filho 1998), (Da Silva Filho e Abe 1998), "introduziu-se circuitos digitais (portas lógicas Complement, And e Or) inspirados nas lógicas anotadas". Tais circuitos permitem sinais "conflitantes", tendo sido construído um "analisador lógico - o para-analisador - que permite tratar conceitos de incerteza, inconsistência e indeterminação". Também foram desenvolvidos controladores lógicos baseados nas lógicas anotadas (paracontrol), simuladores lógicos (parasim) e tratamento de sinais (parasônico) (Abe e Da Silva Filho 2003). Como materialização dos conceitos discutidos, também construiu-se o primeiro robô paraconsistente com o hardware paraconsistente: a robô Emmy (Da Silva Filho e Abe 2001).

A Lógica Paraconsistente Anotada permite, a partir do enunciado de uma proposição, submetê-la ao juízo de determinada pessoa ou grupo de pessoas, estabelecer o formato das suas respostas, promover articulações adequadas dessas respostas, manipular computacionalmente os dados resultantes e, por fim, aplicar um algoritmo de decisão denominado Para-analisador.

Aplicando-se o raciocínio evidencial à proposição formulada, dois valores - o grau de crença ou evidência favorável e o grau de descrença ou evidência contrária podem ser a ela associados, pelo julgamento objetivo e/ou subjetivo de pessoas relacionadas aos temas: denomina-se essa lógica de Lógica Paraconsistente Anotada de anotação com dois valores - LPA2v.

Todavia para aplicação da Lógica Paraconsitente Anotada com dois valores LPA2v, é de fundamental importância discutir o conceito de proposição.

Para isso, buscou-se a referência (Alaôr Caffé Alves 2000) que afirma: "proposição é a expressão verbal do Juízo. O juízo compõe-se de dois conceitos (idéias) e de uma afirmação (um enunciado). O juízo não é uma mera relação entre conceitos, mas sim 
um assentimento, uma asseveração. Ele é enunciativo e, por isso, pressupõe-se sempre uma tomada de posição do sujeito que assevera um conceito a outro."

O que esta conceituação coloca é que uma proposição p, necessária para deflagrar a aplicabilidade da LPA2v, é sempre uma afirmação, na qual está explícita uma decisão. Por outro lado, constata-se que qualquer processo decisório sempre tem caráter de seqüencialidade, durante o qual convivem objetivos concretos com incertezas e indefinições, que precisam ser identificados previamente à formulação de uma determinada proposição sob a forma de fatores de influência e de opções qualitativas ou faixas quantitativas detalhando estes fatores.

Desta forma, uma determinada proposição p poderá ser submetida ao juízo de pessoas, que definiriam um primeiro valor da anotação representando a evidência favorável à cada opção/faixa de cada fator de influência da proposição $\mathbf{p}$ - o grau de crença ou de evidência favorável -, e um segundo valor da anotação representando a evidência contrária à mesma opção/faixa do fator de influência da proposição p grau de descrença ou evidência contrária.

O grau de evidência favorável é simbolizado pela letra $\mu_{1}$ e o grau de evidência contrária pela letra $\mu_{2}$, onde $\left(\mu_{1}, \mu_{2} \in\{x \in R \mid 0 \leq x \leq 1\}\right.$. Considera-se $\left(\mu_{1}, \mu_{2}\right)$ como anotação de p.

Assim, se p é uma proposição e $\left(\mu_{1}, \mu_{2}\right)$ é um valor de anotação, a fórmula $\mathrm{P}_{(\mu 1, \mu 2)}$ pode ser lida: "a evidência favorável de $\mathbf{p}$ é $\mu_{1}$ e a evidência contrária de $\mathbf{p}$ é $\mu_{2}$ ".

Tem-se, assim, alguns exemplos:

- anotação $(1,0)$ pode ser lida como "a evidência favorável de $\mathbf{p}$ é total e a evidência contrária de p é nula", significando intuitivamente que p é uma proposição verdadeira. 
- anotação $(0,1)$ pode ser lida como " a evidência favorável de $\mathbf{p}$ é nula e a evidência contrária de $\mathbf{p}$ é total", significando intuitivamente que $\mathbf{p}$ é uma proposição falsa.

- anotação $(1,1)$ pode ser lida como "a evidência favorável de $\mathbf{p}$ é total e a evidência contrária de $\mathbf{p}$ também é total", configurando que $\mathbf{p}$ é uma proposição contraditória.

- anotação $(0,0)$ pode ser lida como "a evidência favorável de p é nula e a evidência contrária de p também é nula", significando intuitivamente que não temos informação alguma sobre p. Diz-se neste caso que p é uma proposição paracompleta.

- anotação $(0,5 ; 0,5)$ pode ser lida como a "evidência favorável de $\mathbf{p}$ é 0,5 e a evidência contrária de $\mathbf{p}$ é 0,5 ", significando que $\mathbf{p}$ é uma proposição indefinida.

As componentes $\mu_{1}$ e $\mu_{2}$ assumidas como "grau de evidência favorável" atribuído a $\mathbf{p}$ e "grau de evidência contrária" atribuídos a p, respectivamente constituem os valores dos graus de crença e de descrença, e devem ser considerados completamente independentes. Portanto, como um valor não depende absolutamente do outro, é possível qualquer variação dos valores no intervalo real fechado entre 0 e 1 .

A representação das coordenadas $\left(\mu_{1}, \mu_{2}\right)$ pode ser feita no Quadrado Unitário do Plano Cartesiano - QUPC, proporcionando melhor entendimento e visualização. (Vide Figura 1) 


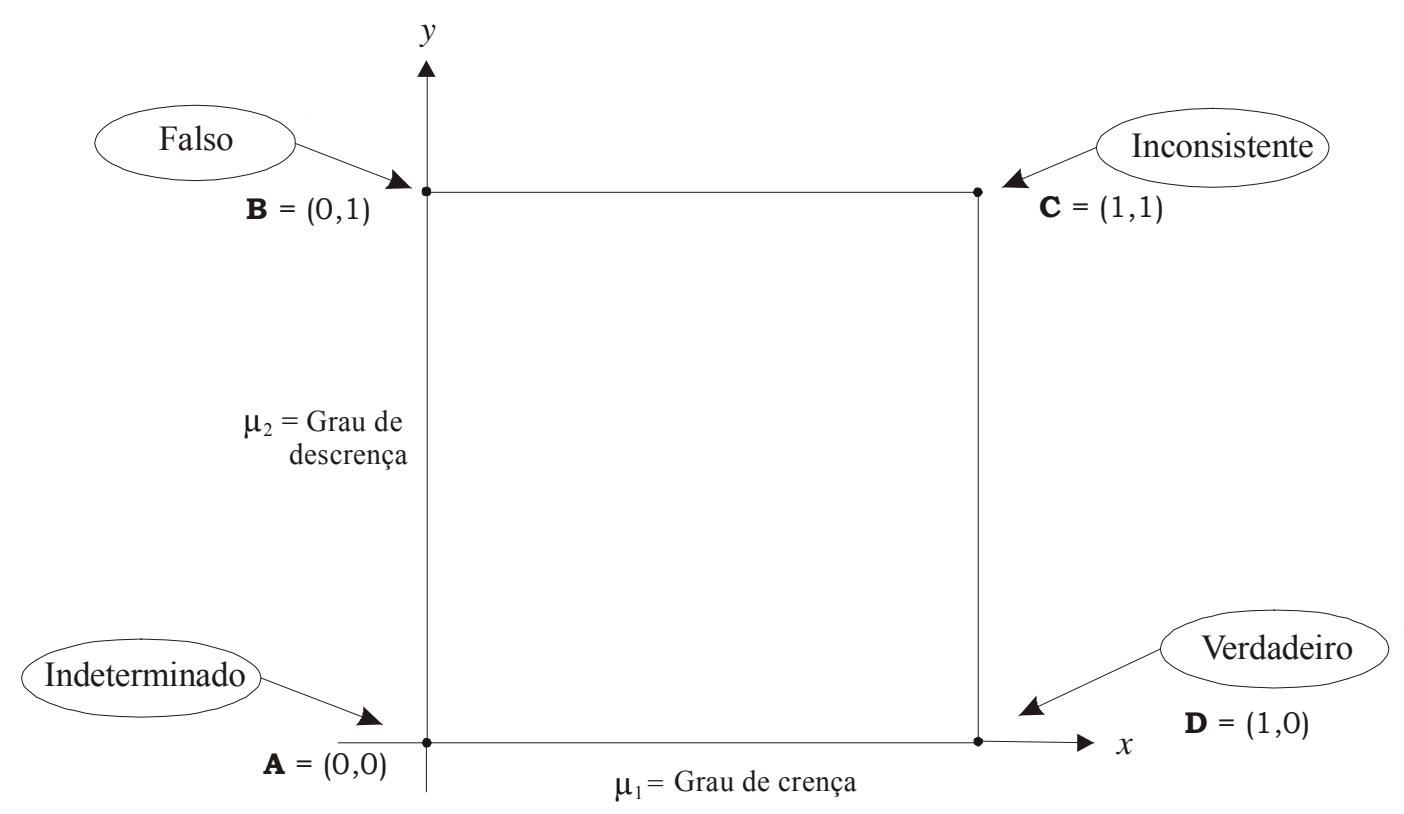

Figura 1:

Sinais de entrada binários, onde $\mu_{1}$ e $\mu_{2}$ valem 0 ou 1, independentemente. Fonte: (Costa, Abe, Silva Filho 1999)

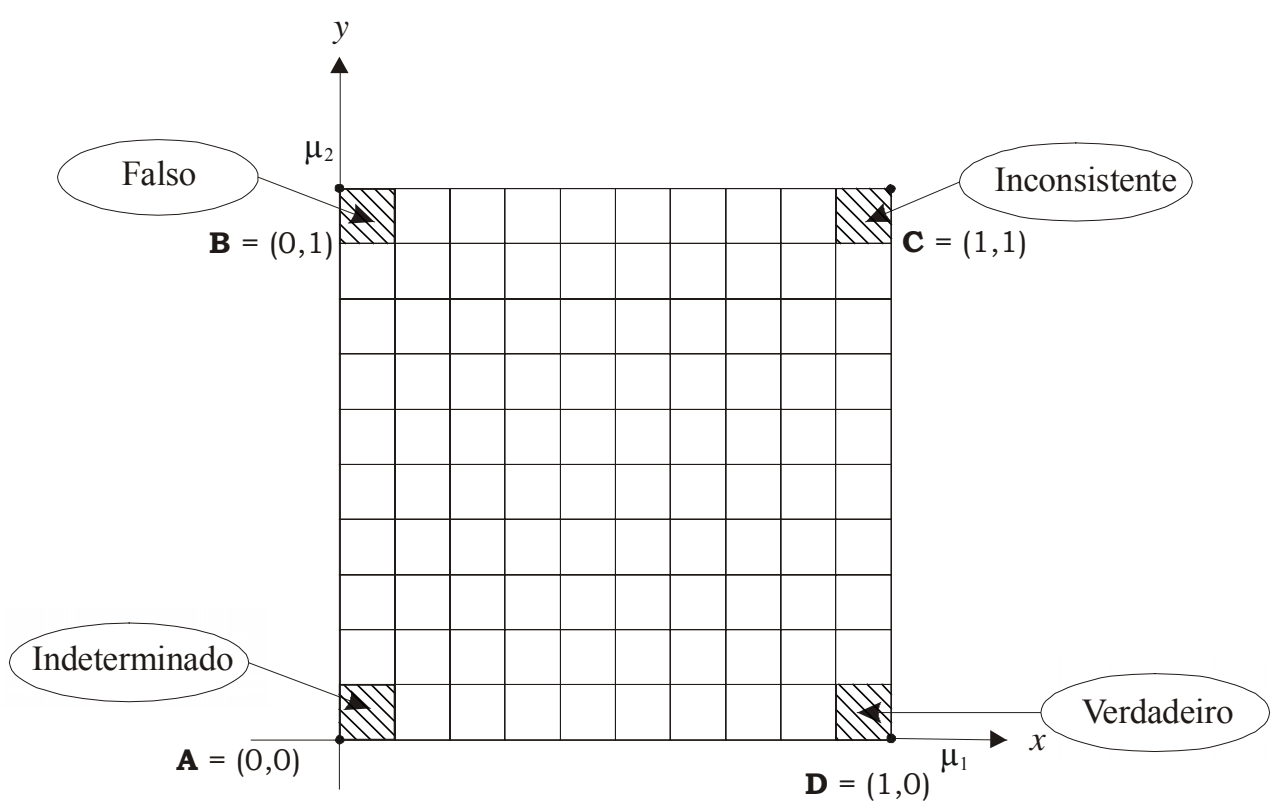

Figura 2:

Reticulado associado à LPA2v pepresentado por um QUPC com discretização dos graus de crença e de descrença 10 e resolução 100.

Fonte: (Costa, Abe, Silva Filho 1999) 
Nessa representação, no eixo $\mathrm{x}$ estão dispostos os valores anotacionais correspondentes ao grau de crença e no eixo y, os valores que correspondem ao grau de descrença. Os pontos assinalados no gráfico determinam os estados extremos do reticulado. São eles:

Ponto $\mathrm{A}=(0,0) \quad \Rightarrow \quad$ indeterminado

Ponto $\mathrm{B}=(1,0) \quad \Rightarrow \quad$ Verdadeiro

Ponto $\mathrm{C}=(0,1) \quad \Rightarrow \quad$ Falso

Ponto $\mathrm{D}=(1,1) \quad \Rightarrow \quad$ Inconsistente

Os valores dos sinais dos graus de crença e de descrença podem ser binários sem nenhuma restrição quanto à relação entre seus valores individuais. Esse caso aproxima-se da proposta apresentada em (Subrahmanian 1987), em que os valores de $\mu_{1}$, e de $\mu_{2}$ podem ser iguais ou diferentes. Como são binários, os resultados obtidos no quadrado unitário do plano cartesiano são estados lógicos, que são denominados de estados extremos e portanto, os estados extremos resultantes, nesse caso, são Falso, Verdadeiro, Inconsistente e Indeterminado.

Fazendo uma análise ponto a ponto no QUPC, pode ser elaborada uma tabela de valores composta pelos graus de crença e pelos graus de descrença e os correspondentes estados lógicos resultantes. 
Tabela 1 - Tabela de valores $\left(\mu_{1}, \mu_{2}\right)$ e estados lógicos resultantes

\begin{tabular}{|c|c|c|}
\hline Graus de crença & Graus de descrença & \multirow{2}{*}{$\begin{array}{c}\text { Estados } \\
\text { Resultantes }\end{array}$} \\
\hline$\mu_{1}$ & $\mu_{2}$ & \\
\hline 1 & 1 & $\mathrm{~T}$-Inconsistente \\
\hline 1 & 0 & V-Verdadeiro \\
\hline 0 & 1 & F- Falso \\
\hline 0 & 0 & $\perp$-Indeterminado \\
\hline
\end{tabular}

Aos valores da tabela 1 , pode ser aplicado o operador NOT que dá sentido de negação, já que procede à inversão entre os valores das anotações $\mu_{1}$ e $\mu_{2}$, resultando numa negação dos estados lógicos resultantes.

Os estados lógicos resultantes da aplicação do Operador NOT com os valores dos graus de crença e de descrença binários e independentes estabelecidos na Tabela 1, são apresentados na Tabela 2. Nesse caso, a tabela é construída com os graus de crença e de descrença com os valores trocados e, pela análise obtida através do quadrado unitário do plano cartesiano(QUPC), são encontrados os estados lógicos resultantes negados.

Tabela 2 -Tabela de valores resultantes da aplicação do Operador NOT

\begin{tabular}{|c|c|c|}
\hline Graus de crença & Graus de descrença & Estados \\
\hline$\mu 1$ & $\mu 2$ & Resultantes \\
\hline 1 & 1 & $\mathrm{~T}$-Inconsistente \\
\hline 0 & 1 & V-Verdadeiro \\
\hline 1 & 0 & F- Falso \\
\hline 0 . & 0 & $\perp$-Indeterminado \\
\hline
\end{tabular}


A Tabela 2 demonstra uma conclusão importante: na aplicação do Operador NOT, a negação ocorre apenas nos estados lógicos resultantes que denotam conotação de certeza, que são os dois estados: "Falso" e "Verdadeiro".

Na Lógica Paraconsistente Anotada considera-se também a aplicação dos conectivos OR e AND, que possuem características semelhantes aos da Lógica Clássica ou da Lógica Fuzzy, ao se considerar a maximização (ou união) para o conectivo OR e a minimização (ou interseção) para o conectivo AND.

Assim, dada uma proposição p com duas anotações $\left(\mu_{1}, \mu_{2}\right)$ e $\left(\lambda_{1}, \lambda_{2}\right)$, para a obtenção do estados lógicos resultantes do conectivo OR é feita primeiramente uma maximização entre os graus de crença, obtendo-se um grau de crença resultante $\mu_{1 R}$. Depois é feita uma maximização entre os graus de descrença, obtendo-se um grau de descrença resultante $\mu_{2 R}$. Com os valores dos graus de crença e de descrença $\left(u_{1 R}\right.$, $\mathrm{u}_{2 \mathrm{R}}$ ), obtém-se o estado lógico resultante, incorporável ao QUPC para análises diversas.

Para obtenção dos estados lógicos resultantes do conectivo AND é feita primeiramente uma minimização entre os graus de crença, encontrando-se um grau de crença resultante $\mu_{1 R}$. Depois, é feita uma minimização entre os graus de descrença, obtendo-se um grau de descrença resultante $\mu_{2 R}$. Com valores dos graus de crença e de descrença resultantes $\left(\mu_{1 R}, \mu_{2 R}\right)$, é feita uma análise no QUPC e obtém-se o estado lógico resultante.

$\mathrm{Na}$ aplicação do conectivo OR em dois valores anotados, quando houver contradição entre eles, isto é, um é "Verdadeiro" e o outro é "Falso", o estado lógico resultante de saída é o "Inconsistente". Da mesma forma, na aplicação do conectivo AND, o estado lógico resultante de saída é "Indeterminado".

Os graus de crença e de descrença também podem ser ternários e independentes. Com valores ternários sendo interpolados no QUPC, tem-se um acréscimo de cinco novos pontos no reticulado. 
$\mathrm{Na}$ consideração binária, foram definidos os estados extremos Inconsistente, Verdadeiro, Falso e Indeterminado. Com os graus de crença e de descrença ternários, os cinco novos pontos definirão cinco novos estados lógicos resultantes, que são denominados de estados não extremos. Cada estado não extremo receberá uma denominação conforme sua proximidade com os estados extremos no QUPC.

Com os sinais dos graus de crença e de descrença multivalorados, são associados pontos situados dentro do QUPC, em que cada ponto representa um estado lógico resultante diferente, que pode ser extremo ou não extremo.

Aumentando-se o número de valores dos graus de crença e de descrença, aumentarão também os pontos interpolados, situados dentro do QUPC. Como cada ponto interpolado corresponde a um estado lógico, esse aumento de pontos situados dentro do QUPC traz como conseqüência um número muito grande de estados lógicos resultantes.

Na prática, o número de estados lógicos desejado depende da finalidade da aplicação da LPA2v. Normalmente, consideram-se os pontos situados muito próximos como os de um mesmo estado lógico resultante. Dessa forma, são obtidas regiões com delimitação de pontos próximos, equivalentes a um único estado lógico resultante. A precisão do processo vai depender do número de regiões que serão delimitadas e também da discretização que será efetuada nos valores de entrada, compostos pelos graus de crença e de descrença que estão sendo aplicados.

Como exemplo, ao ser considerado um valor de entrada composto de graus de crença e de descrença com uma discretização de 10 valores, essa discretização vai resultar em 100 pontos interpolados dentro do QUPC. Isso significa que ter-se-á como saída 100 pontos equivalentes aos estados lógicos resultantes, situados muito próximos uns dos outros.

No quadrado unitário do plano cartesiano (QUPC) é feita então uma otimização com a delimitação de regiões, obtendo-se estados lógicos resultantes correspondentes à 
cada região delimitada. A figura 2 ilustra uma sugestão das denominações dos estados lógicos resultantes correspondentes.

Nessa configuração, as tabelas de valores do Operador NOT e dos conectivos OR e AND são obtidas conforme os procedimentos que foram apresentados para os valores de anotação binários e ternários. Verifica-se que o número elevado de valores dos graus de crença e descrença tem como conseqüência direta o aumento das tabelas de valores decorrentes das aplicações dos operador e conectivos.

Os valores e a descrição feitas no quadrado unitário do plano cartesiano (QUPC), podem ser estendidos para um reticulado representativo da LPA2v, utilizando-se os valores de graus de certeza e de incerteza (ou contradição) descritos como:

Grau de contradição $\left(\mathrm{G}_{\mathrm{cr}}\right)$

onde: $\mathrm{G}_{\mathrm{cT}}=\mu_{1}+\mu_{2}-1 \quad$ para: $0 \leq \mu_{1} \leq 1$ e $0 \leq \mu_{2} \leq 1$

Grau de certeza $\left(\mathrm{G}_{\mathrm{c}}\right)$

onde: $\mathrm{G}_{\mathrm{c}}=\mu_{1}-\mu_{2} \quad$ para: $0 \leq \mu_{1} \leq 1$ e $0 \leq \mu_{2} \leq 1$

O grau de contradição $G_{\text {ст }}$ é definido como o valor medido no reticulado entre os dois estados extremos denominados de Totalmente Indeterminado (-1) e Totalmente Inconsistente (1).

O grau de contradição é composto pelo grau de indeterminação $\mathrm{G}_{\text {id }}(\mathrm{de}-1$ a 0 ) e pelo grau de inconsistência $G_{\text {it. }}$ (de 0 a 1 ). Assim, o valor de grau de contradição está no intervalo real fechado $[-1,1]$.

O grau de certeza $\mathrm{G}_{\mathrm{c}}$ é definido como o valor que representa no reticulado a distância entre os dois estados extremos denominados de Totalmente Falso (-1) e Totalmente Verdadeiro (1). 
Da mesma forma, o grau de certeza $\mathrm{G}_{\mathrm{c}}$ é composto pelo grau de falsidade $\mathrm{G}_{\mathrm{f}}(\mathrm{de}-1 \mathrm{a}$ 0 ) e pelo grau de verdade $G_{v}$ (de 0 a 1 ) com valores no intervalo real fechado $[-1,1]$.

As duas grandezas $\mathrm{G}_{\mathrm{cT}}$ e $\mathrm{G}_{\mathrm{c}}$ estão intimamente ligadas no reticulado representativo da LPA2v, portanto, não se pode determinar o estado resultante tomando-se cada valor de $\mathrm{G}_{\text {ст }}$ e de $\mathrm{G}_{\mathrm{c}}$ individualmente. A inter-relação dos dois graus impossibilita que se faça uma análise de cada valor de modo independente e individual.

Para representar essa dependência e melhorar a visualização dessas grandezas, o grau de contradição poderá ser interposto verticalmente sobre o grau de certeza.

Com a configuração em dois eixos, onde estarão expostos todos os valores possíveis de $\mathrm{G}_{\text {ст }}$ e $\mathrm{G}_{\mathrm{c}}$ (intermediários e extremos), pode-se afirmar que a visualização dos graus de certeza e de contradição em dois eixos, vertical e horizontal, apostos sobre o QUPC, permite obter o reticulado representativo da LPA2v construído com valores passíveis de serem quantificados e equacionados.

As descrições das regiões e as equações que envolvem os valores de entrada e de saída permitem que o algoritmo seja de fácil implementação em linguagem convencional de computação.

O algoritmo construído pela descrição do QUPC, elaborado com base na LPA2v, é denominado "Algoritmo Para-Analisador" e permite a elaboração de programa computacional para diversas aplicações práticas .

As variáveis e as grandezas originadas da Lógica Paraconsistente Anotada, estudadas e definidas no quadrado unitário do plano cartesiano e consolidadas no Algoritmo Para-analisador, podem servir de suporte para análise de qualquer proposição formulada para integrar os sistemas e sub-sistemas de infra-estrutura numa determinada Unidade Territorial Urbana, constituindo-se na proposição metodológica $3 / 2$. 
Reportando-se à Matriz dos Sistemas de Infra-estrutura Urbana, pode-se afirmar que qualquer integração dos sistemas de infra-estrutura será viável, pela manifestação do grau de crença (ou de evidência favorável) e do grau de descrença (ou de evidência contrária) em relação à uma proposição, pelos diversos especialistas dos diversos CCOs, independentemente das suas especificidades e diferenças. 


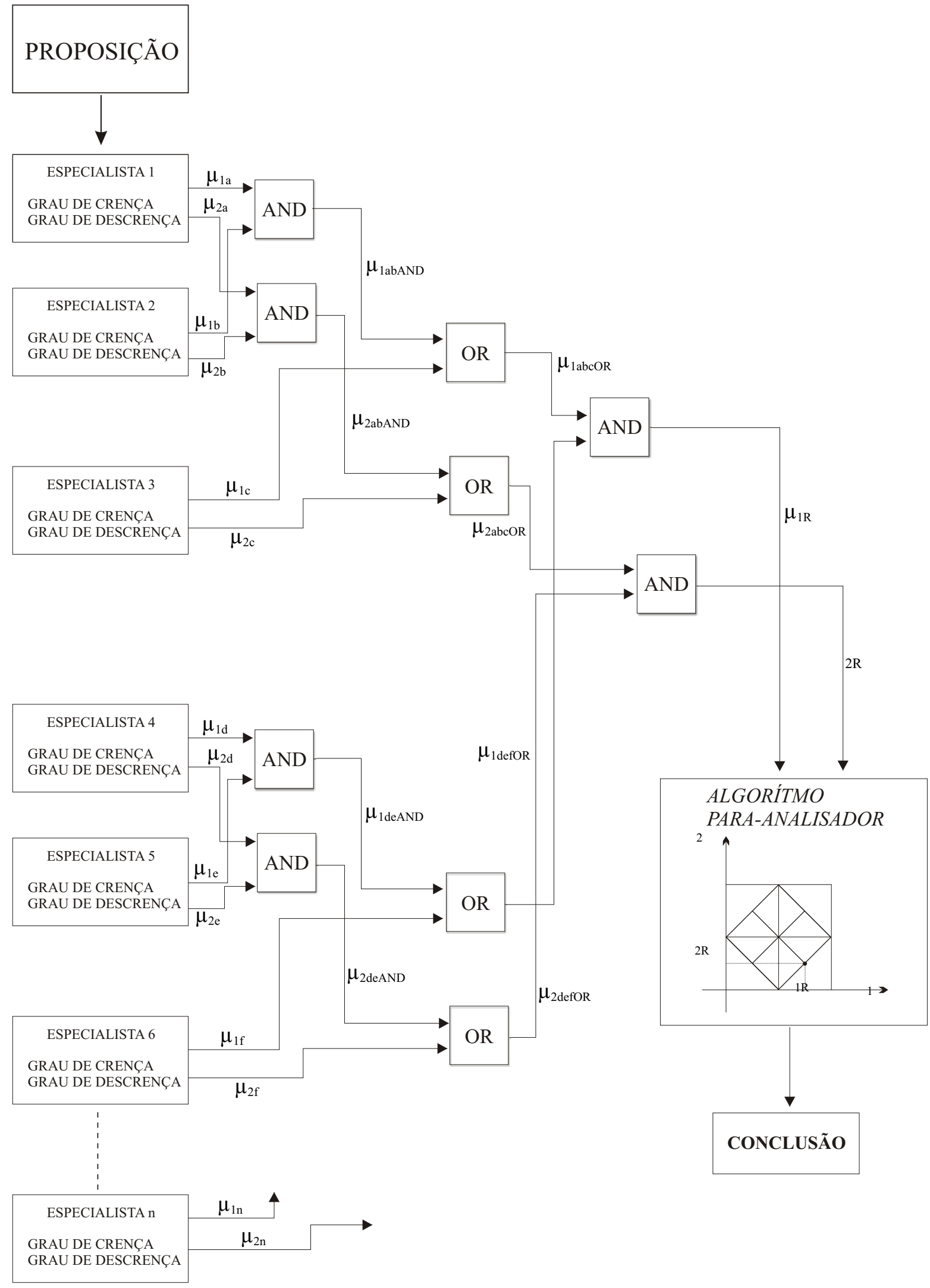

Figura 3:

Rede de sistema especialista paraconsistente para análise da proposição. Fonte: (Costa, Abe, Silva Filho 1999) 
O conjunto de todas as avaliações de todos os especialistas constituirá desta forma uma base de dados, pois que a LPA2v permite integrar vivências profissionais e aptidões individuais.

Conforme ilustrado esquematicamente na Figura 3, pela aplicação sucessiva dos conectivos OR e AND aos diversos graus de crença e de descrença na proposição p definidos pelos especialistas e constantes desta base de dados e pela aplicação final do Algoritmo Para-Analisador para calcular a resultante (ou estado lógico resultante) desses valores, consagra-se uma possibilidade de integração de grande potencialidade e de grande simplicidade.

Desta forma, escolhida uma Unidade Territorial e formulada uma proposição, será possível integrar todos os sistemas afetos, através de uma base de dados paraconsistente processada pelo Algoritmo Para-Analisador o que significará uma notável contribuição para viabilizar a gestão integrada dos sistemas, além de também possibilitar a formulação de Políticas Públicas que explorem as suas complementariedades e explicitem suas deficiências.

\subsection{Síntese das Proposições Metodológicas e Método Adotado}

Para a consolidação de um dos métodos descritos, preparou-se uma síntese das diversas proposições metodológicas através da preparação de um quadro esquemático, enfatizando o seu caráter gradualista (vide Figura 4).

Os métodos que decorrem da Metodologia 1 iniciam-se pela questão primordial: na Unidade Territorial de Análise definida, existe ou não existe cada um dos sistemas e sub-sistemas listados na Matriz dos Sistemas de Infra-estrutura? Em não existindo, registra-se sua inexistência; em existindo, procuram-se dados apenas de suas dimensões físicas e localizações na Unidade Territorial.

No caso da Metodologia 2, a questão inicial continua sendo a existência ou não existência de cada sistema e sub-sistemas, com dimensões físicas e localizações, 
porém ampliando a análise para avaliar qualitativamente os diversos desempenhos dos diversos sistemas e sub-sistemas existentes; desta forma, um índice da regularidade da oferta dos serviços, uma pesquisa de satisfação dos usuários etc numa determinada Unidade Territorial de Análise, permitirá avaliar relativamente os sistemas e sub-sistemas, permitindo integrá-los e homogeneizá-los segundo seus níveis de desempenho.

A Metodologia 3 e os métodos decorrentes dependem da disponibilidade de banco de dados estruturados de sistemas e sub-sistemas que se deseja integrar. Em sendo disponíveis os dados, pode-se partir para a montagem de modelos matemáticos apoiados na variável comum a todos eles que é o tempo. Todavia a condição mais freqüente é uma grande falta de informações disponibilizadas e disponibilizáveis, a qual é suprida normalmente pela determinação de gestores e operadores dos sistemas ligados aos diversos CCOs. Acrescente-se que esta situação - ausência de informações - é praticamente a regra nas cidades brasileiras e em outras cidades com condições sócio-econômicas semelhantes.

Isto posto, o caminho metodológico que se apresenta é a adoção da LPA2v, com a consecução dos passos definidos no item 3: definir Unidade Territorial de Análise, formular uma proposição que integre sistemas de infra-estrutura, submeter tal proposição à avaliação de especialistas, operadores e/ou usuários, e aplicar o Algoritmo Para-analisador, permitindo identificar evidências de complementariedades e de deficiências para viabilização da gestão integrada entre os sistemas de infra-estrutura, objetivada pela proposição formulada. 


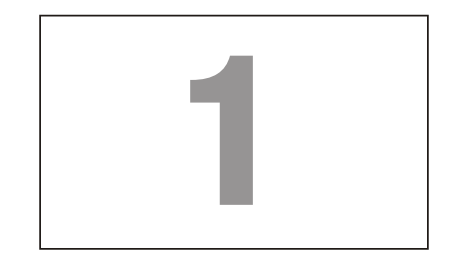

Definição

de U.T.A.

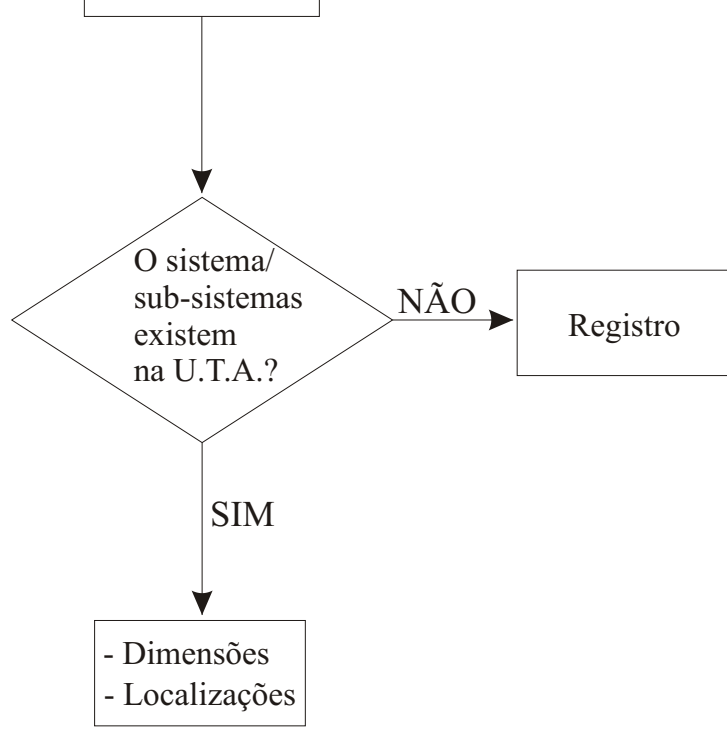

Figura 04

METODOLOGIAS - Esquema-síntese das proposições

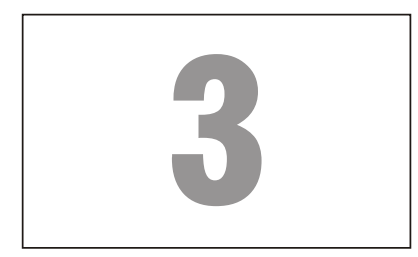

Definição

de U.T.A.

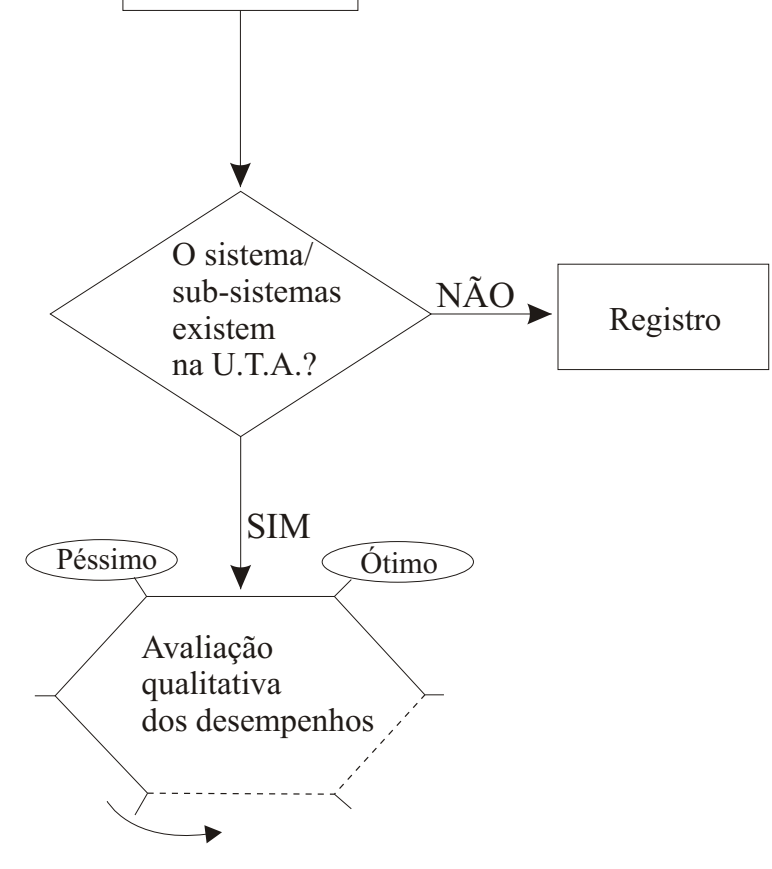

Definição

de U.T.A

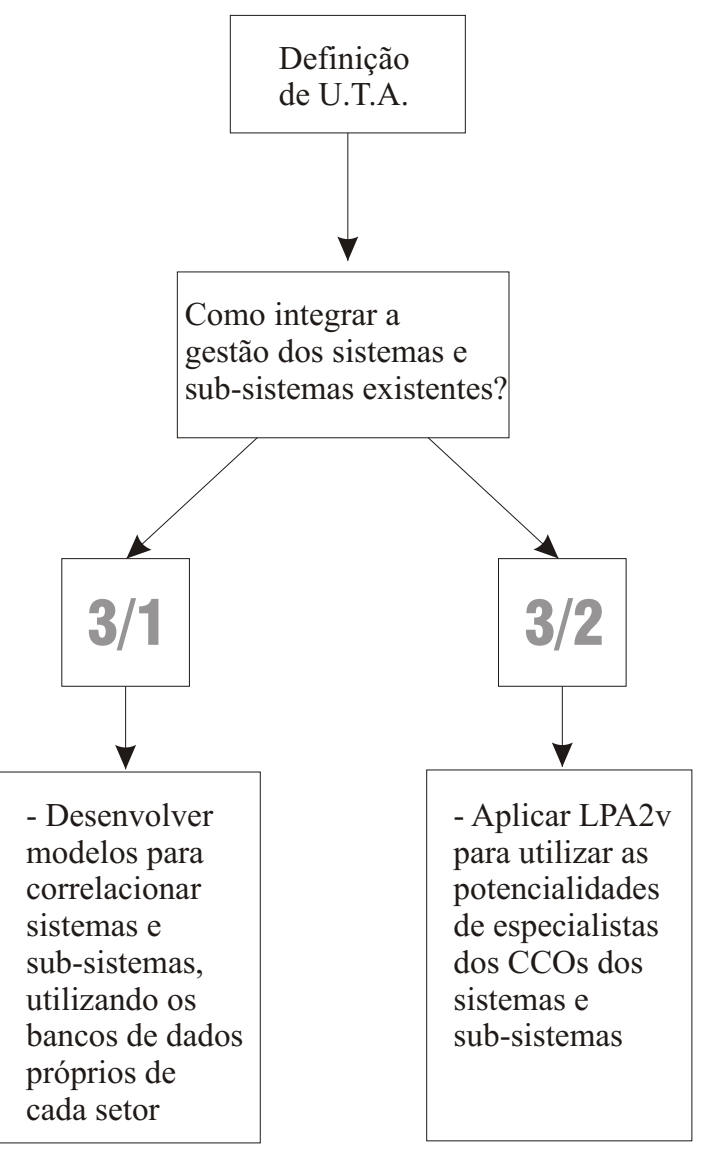




\section{ESTUDO DE CASO ESCOLHIDO: A NAVEGABILIDADE DO CANAL DO RIO PINHEIROS, A OESTE DO MUNICÍPIO DE SÃO PAULO}

Desta forma, o que se propõe para estruturação da tese é inicialmente definir a Unidade Territorial de Análise (UTA). Neste aspecto, opta-se por considerar o Município de São Paulo e Região Metropolitana como locus propício e altamente carente no aspecto integração entre seus sistemas de infra-estrutura.

Nesta região, pode-se discutir inúmeros casos de aplicabilidade do Método da LPA2v a diferentes situações existentes de incomunicabilidade entre os sistemas, objetivando integrá-los. Todavia, define-se pela aplicação de tal Método à Unidade Territorial de Análise Canal do Rio Pinheiros, situado a oeste do Município de São Paulo, como um caso paradigmático de ausência de qualquer interlocução entre as entidades afetas, num quadro de enormes potencialidades.

A UTA Canal do Rio Pinheiros justifica-se pela existência da superposição de atribuições de diversas entidades concessionárias e operadoras de sistemas de infraestrutura: a SABESP com água e esgoto, a EMAE com canais, eclusas, comportas, barragens e elevatórias, o LIMPURB/PMSP com resíduos sólidos, a SIURB/PMSP com implantação de viários estruturais, as sub-prefeituras de São Paulo com manutenção de marginais e demais viários, a CPTM com operação da linha OsascoLargo Treze de Maio, o METRÔ com operação da linha Largo Treze Maio - Campo Limpo e implantação prevista da linha 4-Luz/V.Sônia.

Nesta UTA Canal do Rio Pinheiros, a proposição a ser analisada deverá ser "torná-lo navegável".

A navegação nos corpos d'água da Região Metropolitana de São Paulo, ou seja, na Bacia do Alto Tietê já que seus limites praticamente coincidem, atualmente está restrita em alguns poucos locais, cumprindo funções muito específicas: no Reservatório Guarapiranga, para esportes, lazer e recreação; as 3 travessias de balsa do Reservatório Billings para serviços de transporte coletivo, a raia olímpica da 
Cidade Universitária da USP para esporte, as embarcações de dragagem para manutenção dos canais do Tietê e Pinheiros e algumas outras localidades de menor importância ou freqüência.

Todavia, cabe ressaltar que o sistema hidroviário na Cidade de São Paulo e cidades vizinhas já foi muito importante, havendo dados históricos abundantes deste fato.

Uma constatação desta importância pode ser feita pela análise do Plano de Avenidas elaborado por Prestes Maia, que propõe 3 portos fluviais para a Cidade de São Paulo: porto de Vila Olímpia no Rio Pinheiros e portos da Lapa e na Estação Central, onde haveria integração com ferrovia, aeroporto e marginais, ambos no Rio Tietê. Outra constatação também pode ser feita ao se constatar que existem obras civis já implantadas nos Rios Tietê e principalmente no Rio Pinheiros, que podem não representar a viabilidade atual e futura, mas testemunham planos interrompidos e parcialmente implantados.

A elaboração desta proposição de navegabilidade, dentro do quadro atual de enorme complexidade da Região Metropolitana de São Paulo, implica na perspectiva de integração de ações em diversos sistemas e sub-sistemas de infra-estrutura, tais como coletar, interceptar e tratar os esgotos; completar e operar as eclusas, canais e comportas; varrer ruas e coletar os resíduos sólidos; implantar e manter adequadamente avenidas e vias coletoras adjacentes; implantar portos prevendo integração modal com trem e metrô etc.

Para preparação da proposição da navegabilidade do Canal do Rio Pinheiros, procedeu-se a uma extensa pesquisa histórica dos motivos que levaram à retificação do Rio Pinheiros, relacionados à implantação da geração hidroelétrica em Cubatão.

Constituída esta base informativa inicial, optou-se por proceder à delimitação de Unidade Territorial de Análise para o trecho de $26 \mathrm{~km}$ do Canal, entre as Barragens de Pedreira e Guarapiranga e o Rio Tietê, com a expansão de seus limites de análise 
exclusivamente para um melhor entendimento das características de cada sistema e sub-sistemas afetos.

Em seguida descreve-se, sucinta e didaticamente, a situação atual e o futuro próximo (obras em andamento com conclusão prevista em curto prazo) dos principais sistemas de infra-estrutura que interagem diretamente com a UTA, a saber: sistema rodoviário, sistema ferroviário, sistema esgotos, sistema drenagem e sistema limpeza pública.

Esta coleta de dados, realizada basicamente a partir de reuniões com equipes técnicas responsáveis por diversos centros de controle operacionais e setores de implantação de obras, dos diversos sistemas e sub-sistemas, defrontou-se com algumas das seguintes condições gerais:

- o acesso aos dados operacionais disponíveis em diversos CCOs organizados é restrito e dados relevantes não são normalmente divulgados ao público; uma eventual disponibilização desses dados, mesmo para trabalhos acadêmicos, revelou-se, em alguns casos, bastante difícil e dependente de níveis hierárquicos altos na administração pública afeta;

- em relação às obras em andamento, com conclusão prevista em curto prazo, considerou-se mais adequado considerar as expectativas de suas conclusões e não datas previstas de entrada em operação dos sistemas;

- os casos de CCOs em processo de organização, para os quais os dados sistematizados ainda não estão disponíveis, existindo somente um conjunto de informações históricas abundante porém não sistemática e de difícil análise e processamento, não foram considerados e

- finalmente, existem os casos de organizações institucionais incipientes, onde os CCOs praticamente inexistem, normalmente relacionados aos sistemas e sub-sistemas sem dotações orçamentárias constantes e sem receita tarifária direta, dependendo da transferência eventual de recursos financeiros de origem fiscal. 
Esta constatação de indisponibilidade dos dados operacionais e projeções estratégicas de curto prazo, já prevista no capítulo de discussão metodológica, tem alguns agravantes no caso deste estudo de caso, a saber:

- praticamente não existem órgãos públicos dedicados à implementação de ações administrativas e/ou políticas integrando setores e competências da Administração Pública e Agentes Privados. Em não existindo estes foros, restou apenas e tão somente o contato com cada setor administrativo encarregado de cada sistema e sub-sistema, para ali tentar promover a análise da eventual implementação de uma ação administrativa integrada específica, qual seja a navegabilidade do Canal do Rio Pinheiros;

- por outro lado, esta proposição de navegação corresponde a um problema real da Cidade de São Paulo e Região Metropolitana, relacionado ao seu ambiente construído, que isolou os rios do convívio com seus habitantes, ao mesmo tempo em que as ações administrativas setoriais estão despoluindo-os e tornando-os com atratividade cada vez maior e

- desta forma, qualquer nível de atuação integrada, desde uma simples ação administrativa de várias entidades até a formulação de políticas públicas abrangentes, irá fatalmente redefinir as diversas atuações setoriais, as quais certamente resistirão às mudanças assim como a um processo de avaliação externo do desempenho de seus programas setoriais em implantação.

Não obstante estas considerações, foi possível identificar especialistas no conjunto da Administração Pública afeta aos sistemas e sub-sistemas relacionados na Matriz de Sistemas de Infra-estrutura Urbana, que contribuiram para o embasamento técnico da Proposição, enriquecendo-a substancialmente e além disso, preencheram a Base de Dados Paraconsistente, elencando um conjunto de argumentos justificativos dos graus de evidência favoráveis e contrários à proposição.

Desta forma, tal proposição foi submetida a um conjunto de oito especialistas, identificados em cada entidade operadora ou concessionária, colhendo de cada um deles os graus de crença (evidência favorável) e de descrença (evidência contrária) à proposição circunstanciadamente formulada. 
Ressalte-se que um número de especialistas restrito é uma simplificação sugerida pelo Orientador e Banca da Qualificação e acatada integralmente pelo Orientando, em função da inviabilidade de promover uma consulta mais geral às equipes técnicas em CCOs, aos usuários dos sistemas e sub-sistemas, à população residente nas adjacências do canal etc. Ressalte-se principalmente que tal simplificação não compromete as conclusões sobre aplicabilidade do Método da Base de Dados Paraconsistente à integração de sistemas de infra-estrutura urbana. 


\section{A PROPOSIÇÃO "TORNAR NAVEGÁVEL O CANAL DO RIO PINHEIROS SITUADO A OESTE DO MUNICÍPIO DE SÃO PAULO”}

Transcreve-se neste item 6, a íntegra da Proposição "Tornar Navegável o Canal do Rio Pinheiros situado a Oeste do Município de São Paulo", que foi submetida à avaliação dos oito especialistas em Abril de 2.004 resultando no preenchimento da base de dados paraconsistente. 
SUMÁRIO DA PROPOSIÇÃO

6.1. INTRODUÇÃO

6.2. O SUB-SISTEMA GERAÇÃO DE ENERGIA ELÉTRICA

6.2.1. Descrição Histórica

6.2.2. Situação Atual

6.2. O SISTEMA RODOVIÁRIO AFETO À UTA CANAL DO RIO PINHEIROS

6.3. O SISTEMA FERROVIÁRIO AFETO À UTA CANAL DO RIO PINHEIROS

6.4. O SISTEMA ESGOTOS AFETO À UTA CANAL DO RIO PINHEIROS

6.5. O SISTEMA RESÍDUOS SÓLIDOS AFETO À UTA DO CANAL DO RIO PINHEIROS

6.5.1. Os Sistemas de Limpeza Pública Municipais

6.5.2. $\quad$ O Sub-sistema Dragagem para Desassoreamento do Canal do Pinheiros

6.6. O SISTEMA DRENAGEM AFETO À UTA CANAL DO RIO PINHEIROS

6.7. AVALIAÇÃo DA PROPOSIÇÃO NO QUADRO GERAL DOS SISTEMAS DE INFRA-ESTRUTURA NA UTA CANAL DO RIO PINHEIROS 


\section{$\underline{\text { LISTAGEM DE DESENHOS }}$}

Desenho 5- Mapa Esquemático da Primeira Concessão do Aproveitamento Hidroelétrico na região de São Paulo, segundo estudos de F. S. Hyde em 1924.

Desenho 6- Mapa Esquemático da Primeira Etapa de Implantação do Aproveitamento Hidroelétrico na região de São Paulo em 1927.

Desenho 7- Mapa Esquemático da Segunda Concessão do Aproveitamento Hidroelétrico na região de São Paulo, 1928-1994.

Desenho 8- Situação Final do Aproveitamento Hidroelétrico do Alto Tietê Cubatão. Esquemas em planta e perfil.

Desenho 9- Esquema Ilustrativo dos $26 \mathrm{~km}$ do Canal do Rio Pinheiros em planta, perfil e seções.

Desenho 10- Esquema do Canal do Rio Pinheiros e Sistema Rodoviário

Desenho 11- Esquema do Canal do Rio Pinheiros e Sistema Ferroviário

Desenho 12- Esquema do Canal do Rio Pinheiros e Sistema Esgotos

Desenho 13- Esquema do Canal do Rio Pinheiros e Sub-sistema Dragagem

Desenho 14- Esquema do Canal do Rio Pinheiros e Sistema Drenagem

Desenho 15- Esquema Geral do Canal do Rio Pinheiros

FOTOS AÉREAS F.P.H.E.S.P - 12 FOTOS

LISTAGEM DE QUADROS

Quadro 2: BASE DE DADOS PARACONSISTENTES

Quadro 3: MATRIZ DOS SISTEMAS DE INFRA-ESTRUTURA URBANA À UTA CANAL DO RIO PINHEIROS 


\section{PROPOSIÇÃO “Tornar navegável o Canal do Rio Pinheiros, situado a oeste do Município de São Paulo”.}

\subsection{INTRODUÇÃO}

Para explicitação, ao conjunto dos especialistas, da proposição "Tornar Navegável o Canal do Rio Pinheiros situado a oeste do Município de São Paulo", elaborou-se inicialmente uma descrição histórica detalhada da implantação do Canal e da sua situação atual relativamente à Geração Hidroelétrica nas Bacias Alto Tietê e Cubatão; em seguida, procedeu-se à descrição da estruturação do sistema rodoviário, do sistema ferroviário, do sistema esgotos, do sistema resíduos sólidos e do sistema drenagem afetos à Unidade Territorial de Análise.

Baseados nestas descrições são identificados, na Matriz dos Sistemas de Infraestrutura, todos os Componentes de Grupos Afins, de Sistemas e Sub-sistemas, para avaliação da proposição formulada. Com este universo de componentes conhecido, é então definido, nos diversos campos de especialidades relacionadas àquela Proposição, quantos e quais especialistas serão mobilizados

Em seguida, é preparado o Quadro da Base de Dados para coleta do graus de evidência favorável e contrária de cada especialista, para diversos fatores de influência, opções e faixas relacionados à Proposição e aos Componentes

Por último, finaliza-se o texto da proposição com uma avaliação sucinta, inserindo esta U.T.A. - Unidade Territorial de Análise Canal do Rio Pinheiros, no contexto mais geral do desenvolvimento urbano e dos sistemas de infra-estrutura urbana da Região Metropolitana de São Paulo. 


\subsection{SUB-SISTEMA GERAÇÃO DE ENERGIA ELÉTRICA}

\subsubsection{Descrição Histórica}

Em 1891, a Cidade de São Paulo recebeu iluminação elétrica, fornecida por uma máquina a vapor utilizando lenha, com $50 \mathrm{~kW}$ de potência da Companhia de Água e Luz do Estado de São Paulo.

Em 1899/1900, a empresa “The São Paulo Railway Light and Power Co.”, fundada no Canadá, é autorizada a funcionar em São Paulo pelo Governo Inglês, absorvendo aquela companhia e dois sistemas de transportes coletivos da cidade (Morse 1970). Esta denominação foi modificada para "São Paulo Tramway Light and Power Co." para evitar confusão com a firma inglesa "São Paulo Railway Co." concessionária da Estrada de Ferro Santos a Jundiaí, conservando tal denominação até 1956.

A 7 de maio de 1900, é inaugurada pela Light, a primeira linha de bondes elétricos em São Paulo, servindo ao bairro da Barra Funda; para tal fim, foi construída uma usina termoelétrica de $550 \mathrm{~kW}$.

Já em 1901, entrava em operação, sem regularização das vazões do Rio Tietê, a Usina Hidroelétrica de Santana de Parnaíba, com potência instalada inicial de 2.000 kW. Após a conclusão da Barragem e formação do Reservatório do Guarapiranga em 1906, configurando a primeira intervenção para regularização de vazões nas Bacias do Rio Pinheiros e do Alto Tietê, sua potência foi sendo ampliada gradativamente atingindo $16.000 \mathrm{~kW}$ em 1912. Em 1912, é inaugurada a Usina de Geração Termoelétrica da Rua Paula Souza,às margens do Rio Tamanduaté́, região central da Cidade de São Paulo, com 5.000 kW. Em 1914, entram em produção três grupos geradores da usina de Itupararanga (Rio Sorocaba, Médio Tietê), perfazendo 33.300 kW, que seriam ampliados para $57.000 \mathrm{~kW}$ em 1925.

A extraordinária seca dos anos de 1924 e 1925 obrigava a soluções urgentes: em 1924 ampliava-se Paula Souza para $10.000 \mathrm{~kW}$ e em 1925, era construída a 
Hidroelétrica de Rasgão, no Rio Tietê a jusante de Santana de Parnaíba, em tempo recorde, adicionando $18.500 \mathrm{~kW}$ à potência disponível para São Paulo.

Nesta época, a Cidade de São Paulo estava com 700.000 habitantes, já esboçando os contornos de uma grande metrópole, tornando viável em todos os sentidos, um grande empreendimento no setor energético.

Em1922, chega ao Brasil o eng. Asa White Kenney Billings, que encarrega o eng. F. S. Hyde para identificar locais da Serra do Mar, nas vertentes oceânica e continental próximas de São Paulo, para a implantação de um aproveitamento hidroelétrico óbvio, qual seja, a reversão dos rios do planalto paulista para a vertente oceânica (Ackermann 1953).

O eng. Walter Charnley, dentro desta concepção, já tinha estudado dois locais durante a década de 1910: um deles consistia na reversão do Rio Paraibuna, formador do Paraíba e o outro, na reversão do Tietê para a bacia do Rio Itapanhaú, através de uma barragem no local denominado Ponte Nova.

O Eng. F. S. Hyde optou por uma concepção de implantação e interligação de vários reservatórios em diversos rios da Bacia do Alto Tietê, reunindo suas vazões no Reservatório Rio Grande, com nível máximo de 738,00 m, encaminhando a descarga ao Reservatório das Pedras e daí para as turbinas locadas junto ao rio Cubatão, na Baixada Santista, no sopé da Serra do Mar, à cota 10,00 m (vide Desenho 5).

A possibilidade de construção do sistema em etapas, de interesse da concessionária, e o controle de enchentes nas várzeas do Rio Tietê, no trecho urbano da Cidade de São Paulo, facilitariam as tramitações do pedido de concessões. Desta forma, o Decreto Federal no 16.844 de 27 de Março de 1925, aprovou o plano de obras de F. S. Hyde, ficando a "The São Paulo Tramway, Light and Power Co." obrigada a "... não prejudicar o abastecimento de água das populações que seriam naturalmente servidas pelos mananciais a captar". Sobre o mesmo plano, a Lei Estadual no 2109 de 29 de dezembro de 1925 estabelece que a construção das barragens será “... de modo a 


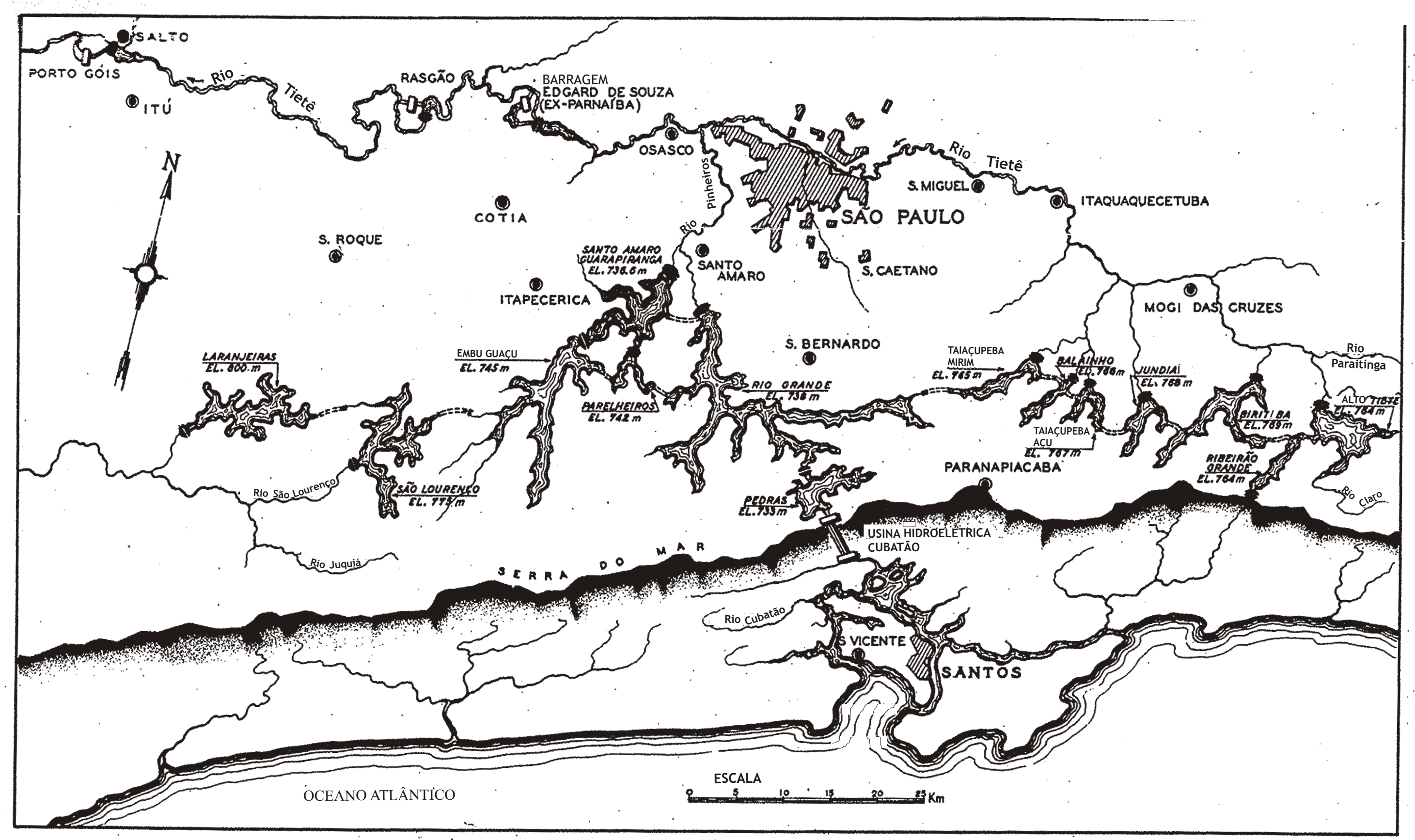

DESENHO 05

Mapa esquemático da Primeira Concessão do Aproveitamento Hidroelétrico na Região de São Paulo, segundo estudos de F. S. Hyde em 1924. 


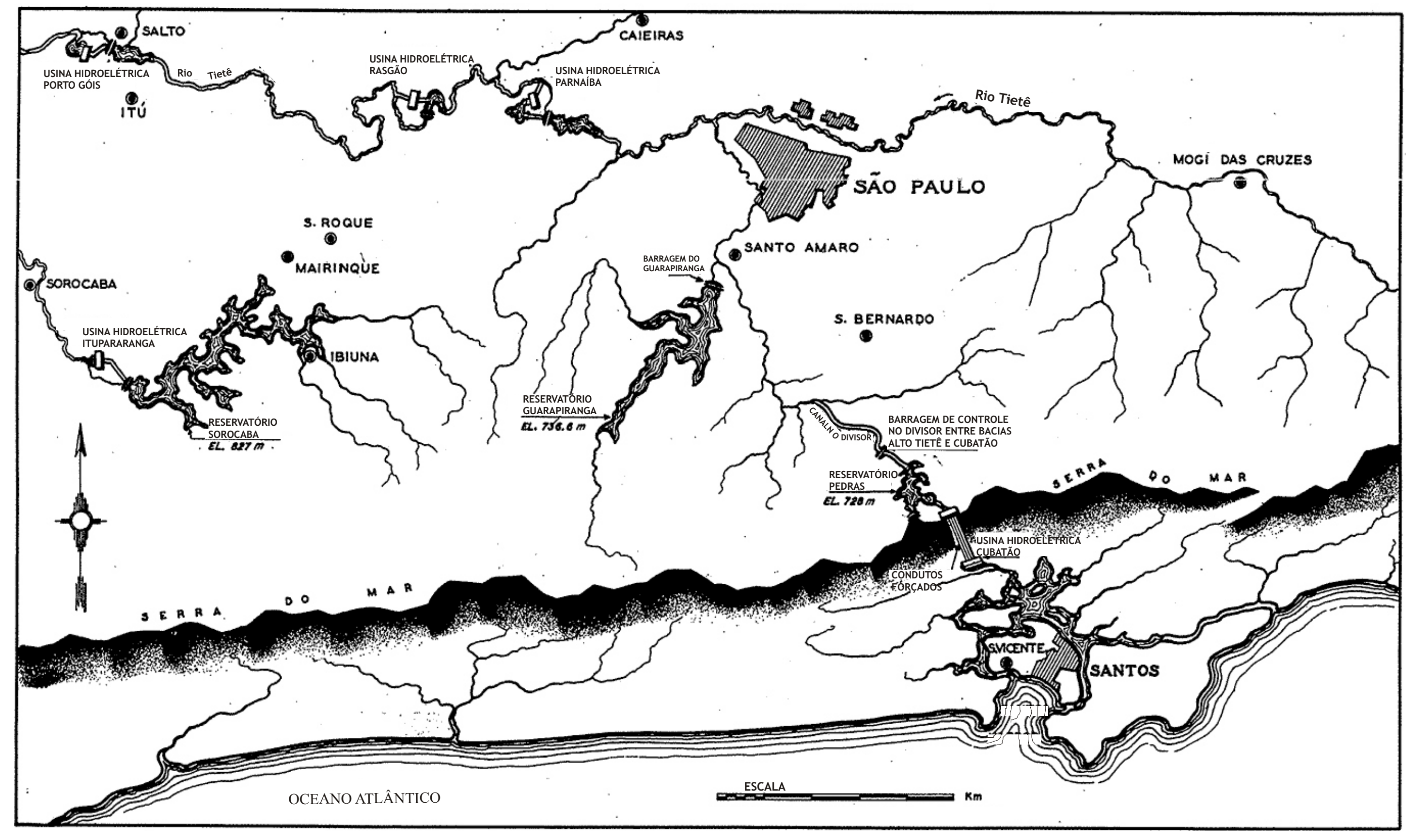


evitar as inundações dos margens do Rio Tietê, sem diminuir a vazão normal desses rios na época de estiagem ...".

Implantada a primeira etapa da Usina Hidroelétrica de Cubatão, que constava do Reservatório do Rio das Pedras, de um canal de derivação de vazões do Rio Grande a fio d'água (ver Desenho 6), e montagem de duas unidades geradoras de $35.000 \mathrm{~kW}$ cada, a concessionária altera radicalmente a concepção proposta pelo eng. F. S. Hyde; substituindo as barragens do Alto Tietê a montante da Cidade de São Paulo, pelas obras de canalização do Rio Pinheiros e implantação de duas estações elevatórias, possibilitando a inversão do seu curso e permitindo captar o Rio Tietê sem regularização, regularizando tais contribuições no Reservatório do Rio Grande, pelo aumento do seu volume, que subiria da cota 736,00 para a cota máxima 746,50 m (vide Desenho 7).

Além disto, seria estabelecido um sistema inter-modal para serviços de transporte de carga entre São Paulo e o Porto de Santos, com uma parte hidroviária, através da navegação do Canal do Rio Pinheiros com duas eclusas, acessando o Reservatório Rio Grande, e outra parte, através de sistema especial, ligando a região entre os Reservatórios Rio Grande e Pedras e a Baixada Santista, vencendo o desnível da Serra do Mar. Conforme estabeleceu a Lei Estadual no 2249 de 27 de dezembro de 1927, esta transposição seria viabilizada adotando o método “... o mais conveniente, quer seja o aéreo, quer seja a condução de embarcações em tanques apropriados". O novo pedido de concessão recebeu, desta forma, o aval e a concordância do Governo do Estado de São Paulo.

Registraram-se algumas tentativas de redefinição das concessões e de nacionalização da companhia, destacando-se o Decreto - Lei Federal nº 852 de 1938, que no seu artigo $6^{\circ}$ diz que “... os aproveitamentos de quedas d'água destinados a serviços públicos, de utilidade pública ou ao comércio de energia, só poderão ser concedidos a brasileiros, ou a Estados e Municípios, ou a Sociedades Brasileiras organizadas 
segundo normas seguintes ..."; este decreto porém, foi em parte revogado em 1940, através do Decreto - Lei Federal no 2059.

O processo decorrente desta mudança radical da concepção do Aproveitamento Hidroelétrico das Bacias do Alto Tietê e Cubatão, pode ser claramente visualizado e avaliado na seqüência de 12 fotos aéreas realizadas pela Light em 08 de maio de 1941, durante as obras de canalização do Rio Pinheiros, Estas fotos aéreas, onde ainda podem ser observados os seus meandros, desde a Barragem do Rio Grande (foto 1) até a foz do Rio Tietê (foto 12), constituem parte do enorme acervo da Fundação Patrimônio Histórico da Energia de São Paulo, são objeto de descrição individualizada a seguir:

\section{foto 1}

- a Barragem de Pedreira/Reservatório do Rio Grande atual Billings, configura a seção inicial do Canal do Rio Pinheiros, à estaca $0 \mathrm{~km}+0,00 \mathrm{~m}$;

- à margem direita, observa-se trecho da Av. Nossa Senhora do Sabará, que dá acesso à ombreira direita da barragem e ao centro operacional do sistema;

- à margem esquerda, nota-se obra de implantação do Autódromo de Interlagos.

\section{foto 2}

- a seção do canal à estaca $3 \mathrm{~km}+0,00 \mathrm{~m}$, constitui aproximadamente a posição da atual Ponte de Interlagos, com a avenida já traçada em ambas as margens;

- a via mais próxima e paralela à margem esquerda do canal é a Rua Olívia Penteado que prossegue como Av. do Rio Bonito;

- a malha viária apoiada nestas vias refere-se aos bairros Veleiros e Interlagos em Capela do Socorro.

\section{foto 3}

- o centro de Santo Amaro implantado próximo ao leito natural do rio, fica distante da margem esquerda do canal e ganha a possibilidade de novas áreas de expansão urbana para toda a região de meandros entre o leito natural e o canal;

- a Ponte do Socorro, já locada na altura da estaca $5 \mathrm{~km}+800 \mathrm{~m}$, tem acesso pelo traçado da atual Av. Washington Luis;

- à margem esquerda do canal, vê-se o maciço da Barragem Guarapiranga, uma parte inicial do lago e todo o Canal.do Guarapiranga. 


\section{foto 4}

- é uma foto de articulação, sem informação relevante.

\section{fotos $5,6,7$ e 8}

- o Canal do Guarapiranga encontra o Canal do Rio Pinheiros à estaca 7 km + 0,00 m, com curvatura adequada para dirigir suas contribuições ao Reservatório Rio Grande/Billings.

- na altura da estaca $9 \mathrm{~km}+800,00 \mathrm{~m}$, contata-se a Ponte João Dias já implantada, para ligação rodoviária de Santo Amaro à Estrada de Itapecerica.

- da estaca $9 \mathrm{~km}+$ 0,00 m (Ponte João Dias) à estaca $13 \mathrm{~km}+0,00 \mathrm{~m}$ (Ponte do Morumbi) passando pela Elevatória de Traição $(15 \mathrm{~km}+500,00 \mathrm{~m})$ e chegando até à Ponte Cidade Jardim $(16 \mathrm{~km}+400,00 \mathrm{~m})$, nota-se mais claramente o partido do projeto do canal, já presente nos trechos anteriores (desde a estaca $1 \mathrm{~km}+$ 0,00 m), de deslocar o eixo do canal retificado para oeste, ganhando áreas extensas para urbanização na sua margem direita, adjacentes à Chácara Santo Antônio, à Vila Olímpia e às Ruas do Império (atual Horácio Lafer) e do Porto (atual Leopoldo Couto de Magalhães).

\section{fotos 9,10 e 11}

- a partir da ponte Cidade Jardim (estaca $16 \mathrm{~km}+400,00 \mathrm{~m}$ ) constata-se um movimento organizado de implantação do canal conjuntamente com equipamentos importantes nas margens, destacando-se a Cidade Universitária, desde a estaca $20 \mathrm{~km}+300,00 \mathrm{~m}$ (posição da futura ponte) até estaca $22 \mathrm{~km}+$ 400,00 m; o Distrito Industrial do Jaguaré, com a ponte e a Av. Queiroz Filho já implantadas pelos proprietários dos lotes industriais e das residências operárias próximas e o Jockey Club entre as Pontes Cidade Jardim e Eusébio Matoso (estaca $18 \mathrm{~km}+300,00 \mathrm{~m}$ ).

\section{foto 12}

- na estaca $25 \mathrm{~km}+100,00 \mathrm{~m}$, nota-se o conjunto de comportas no canal do Rio Pinheiros, denominadas Comportas do Retiro, cuja função era impedir que as cheias do Tietê adentrassem as áreas baixas vizinhas ao Pinheiros;

- na estaca $25 \mathrm{~km}+200,00 \mathrm{~m}$, a ponte da Estrada de Ferro Sorocabana, da Linha Estação Júlio Prestes - Osasco - Oeste do Estado, já está implantada; 
- à margem direita, vê-se cerca de $3 \mathrm{~km}$ sem urbanização, desde o Canal até a Av. Imperatriz Leopoldina já implantada, onde seria construído o CEAGESP 


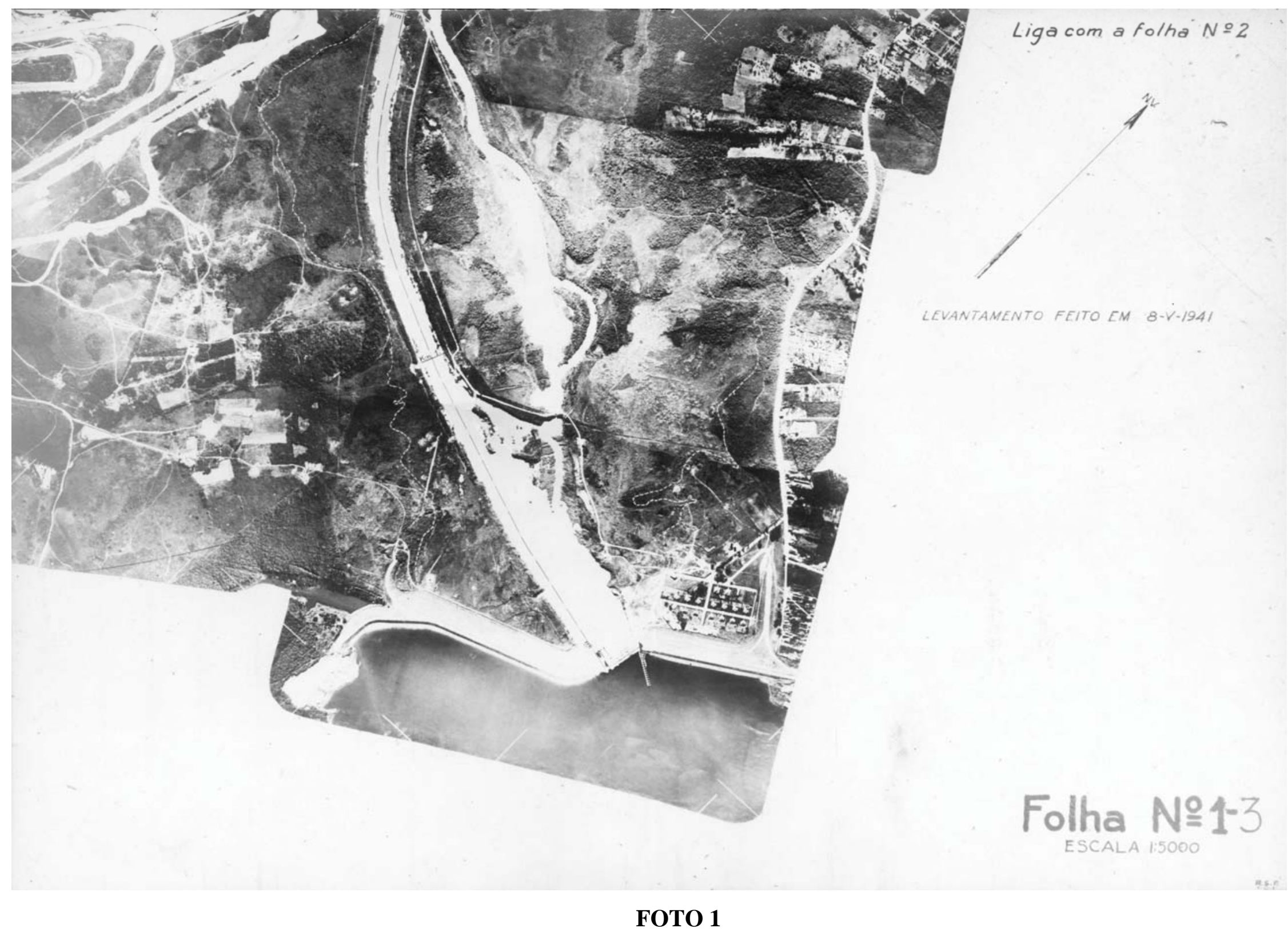




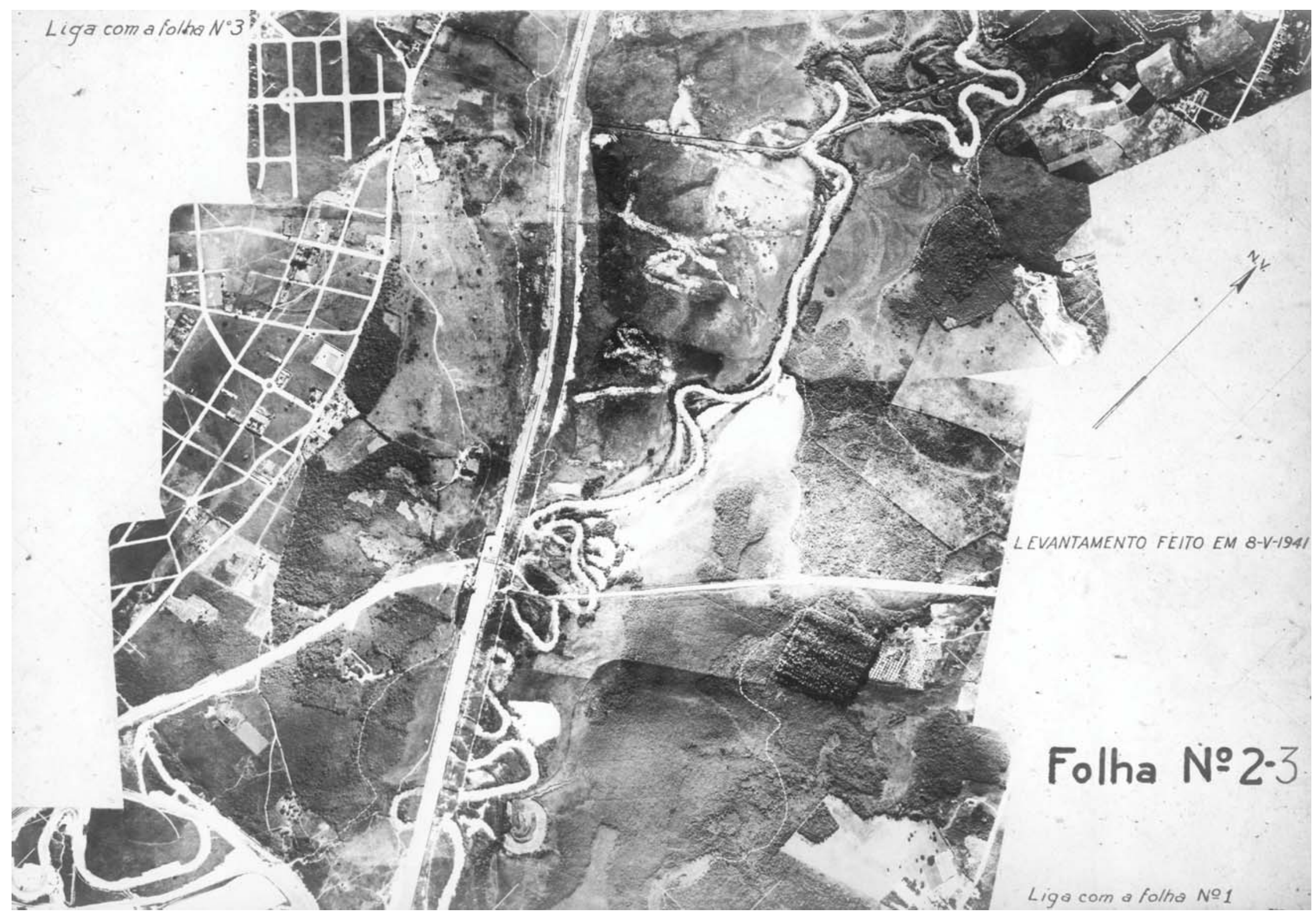

FOTO 2 


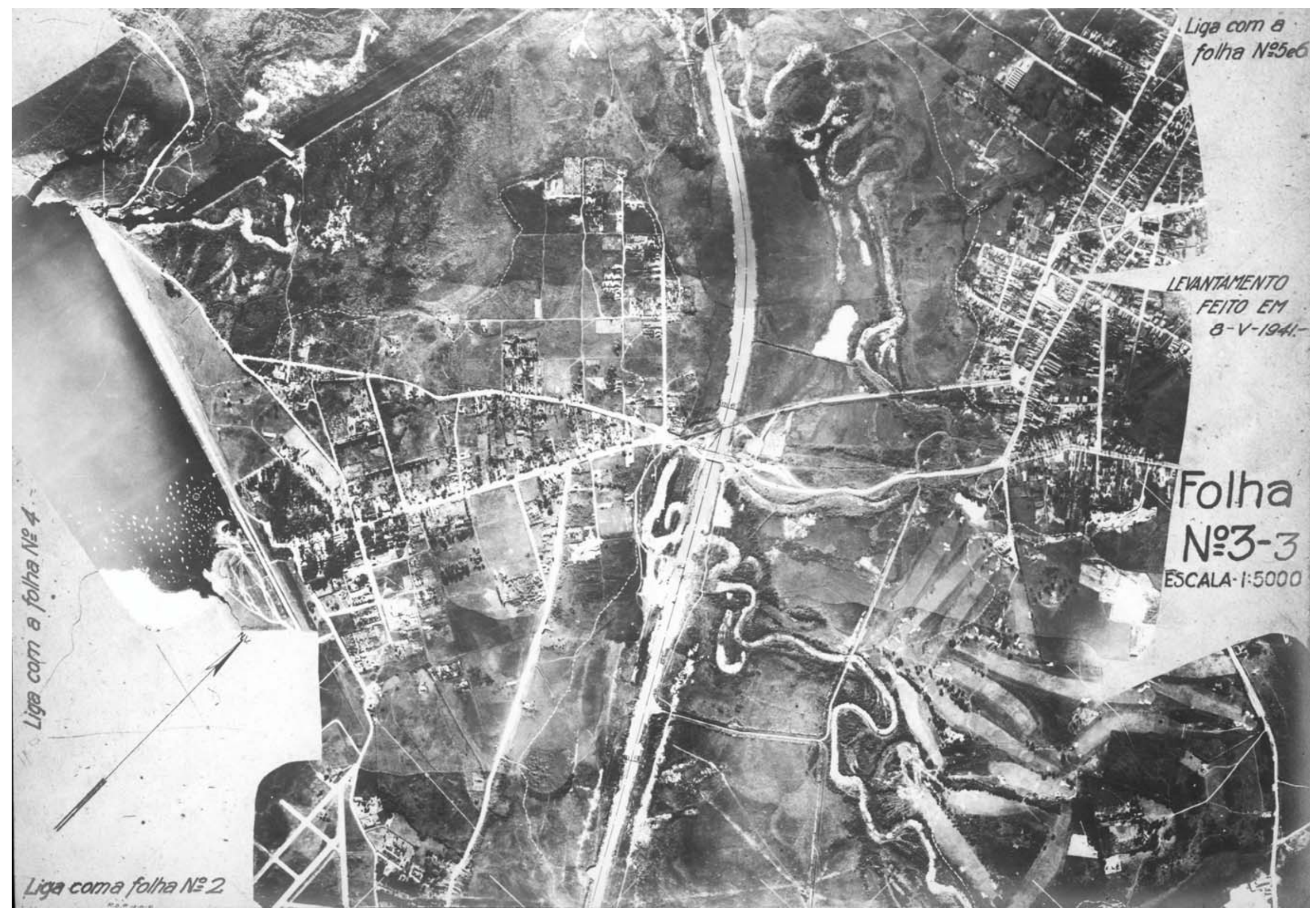

FOTO 3 
4

Folha $N \cong 4-3$

$$
\text { ESCALA - 1:5000 }
$$

LEVANTAMENTO FEITO EM \&-V-194I

FOTO 4 


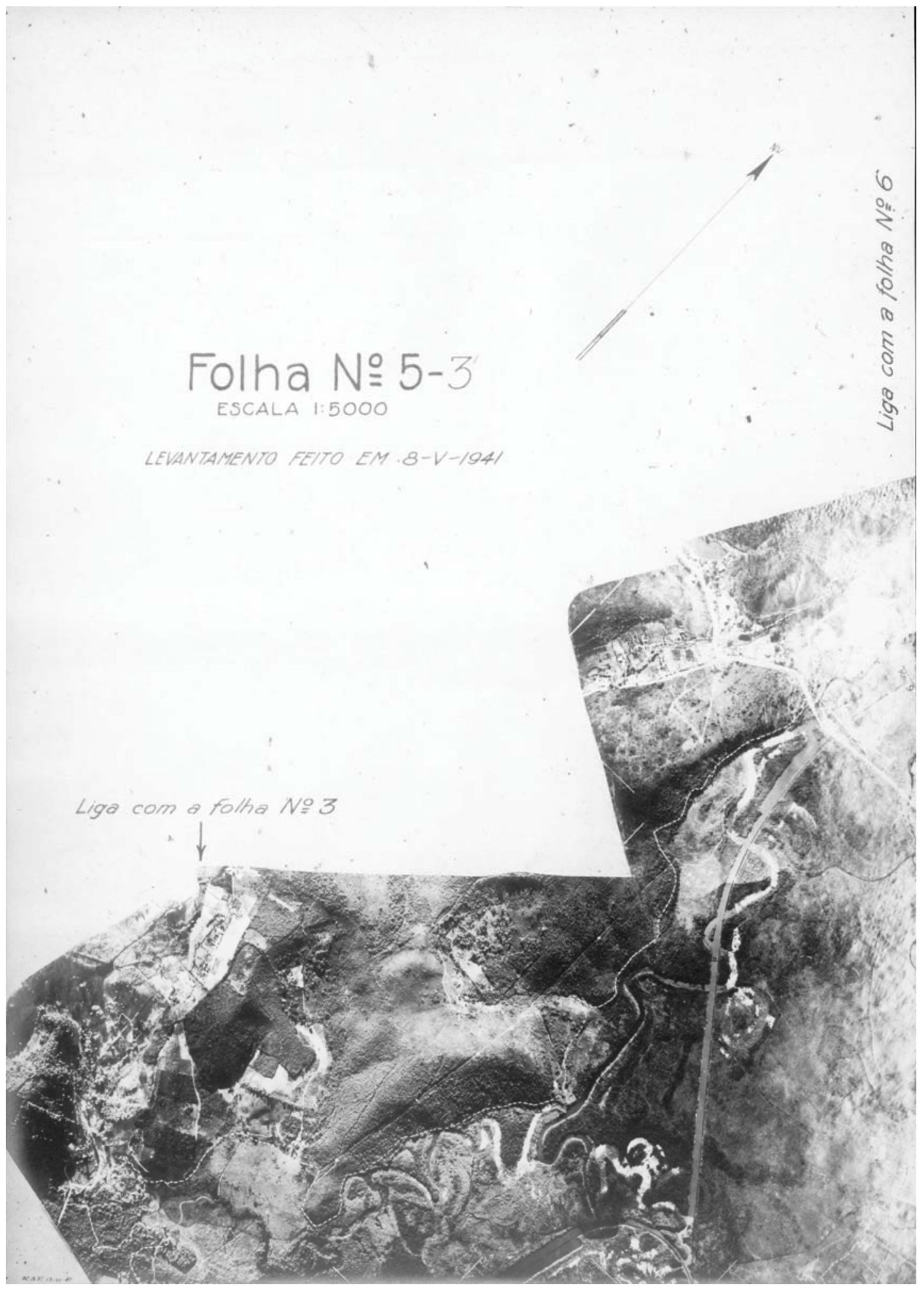

FOTO 5 


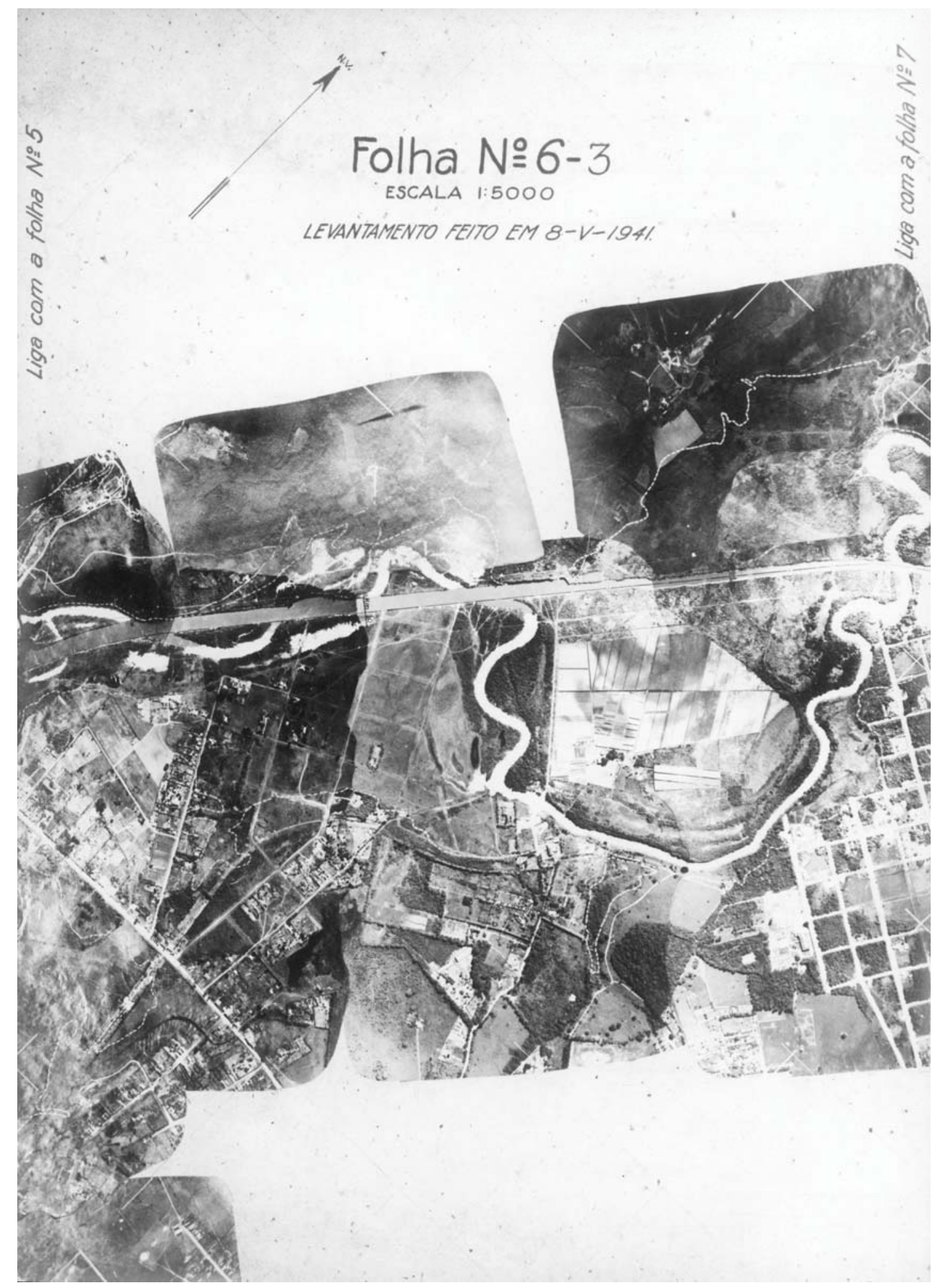

FOTO 6 


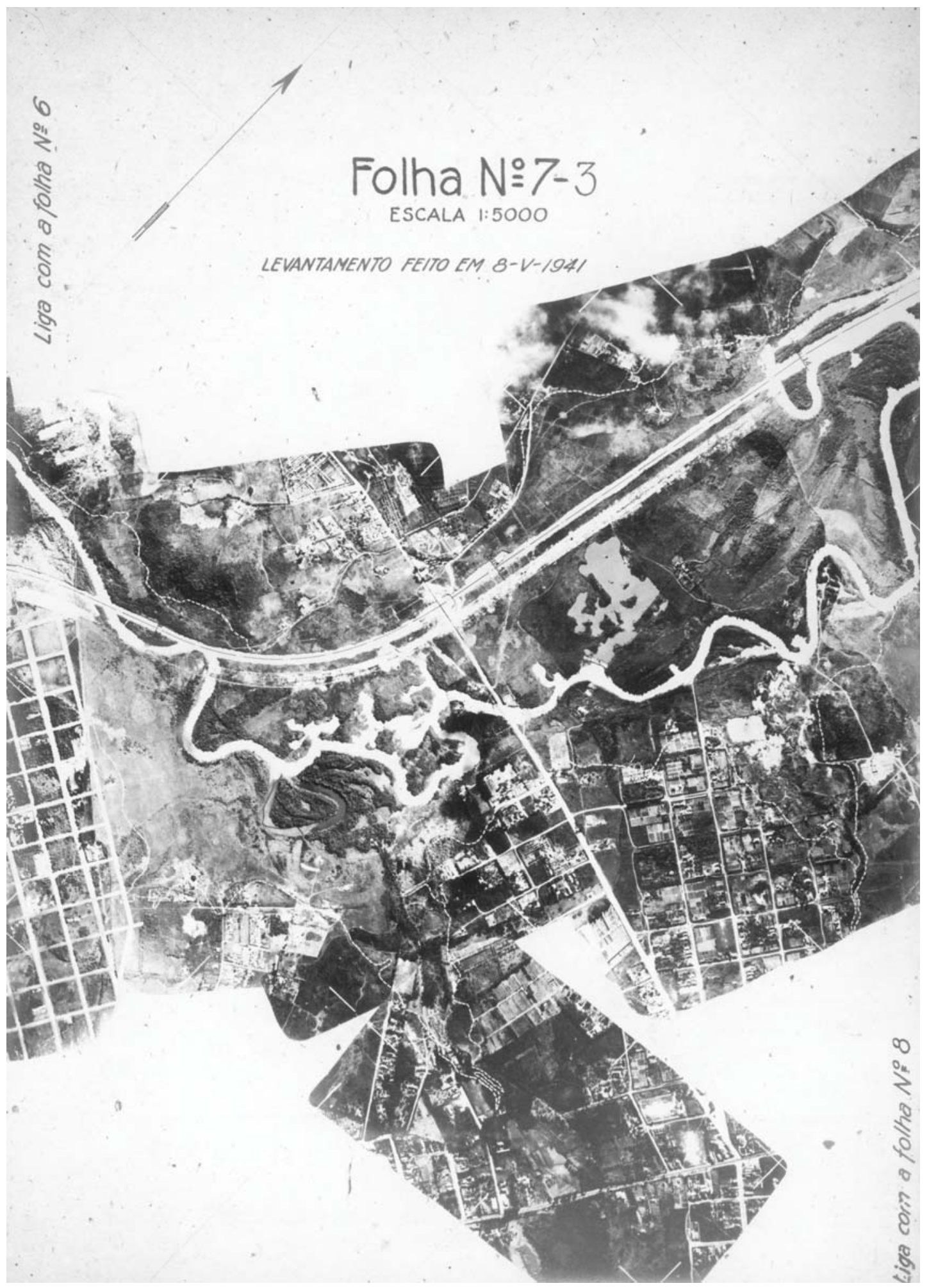




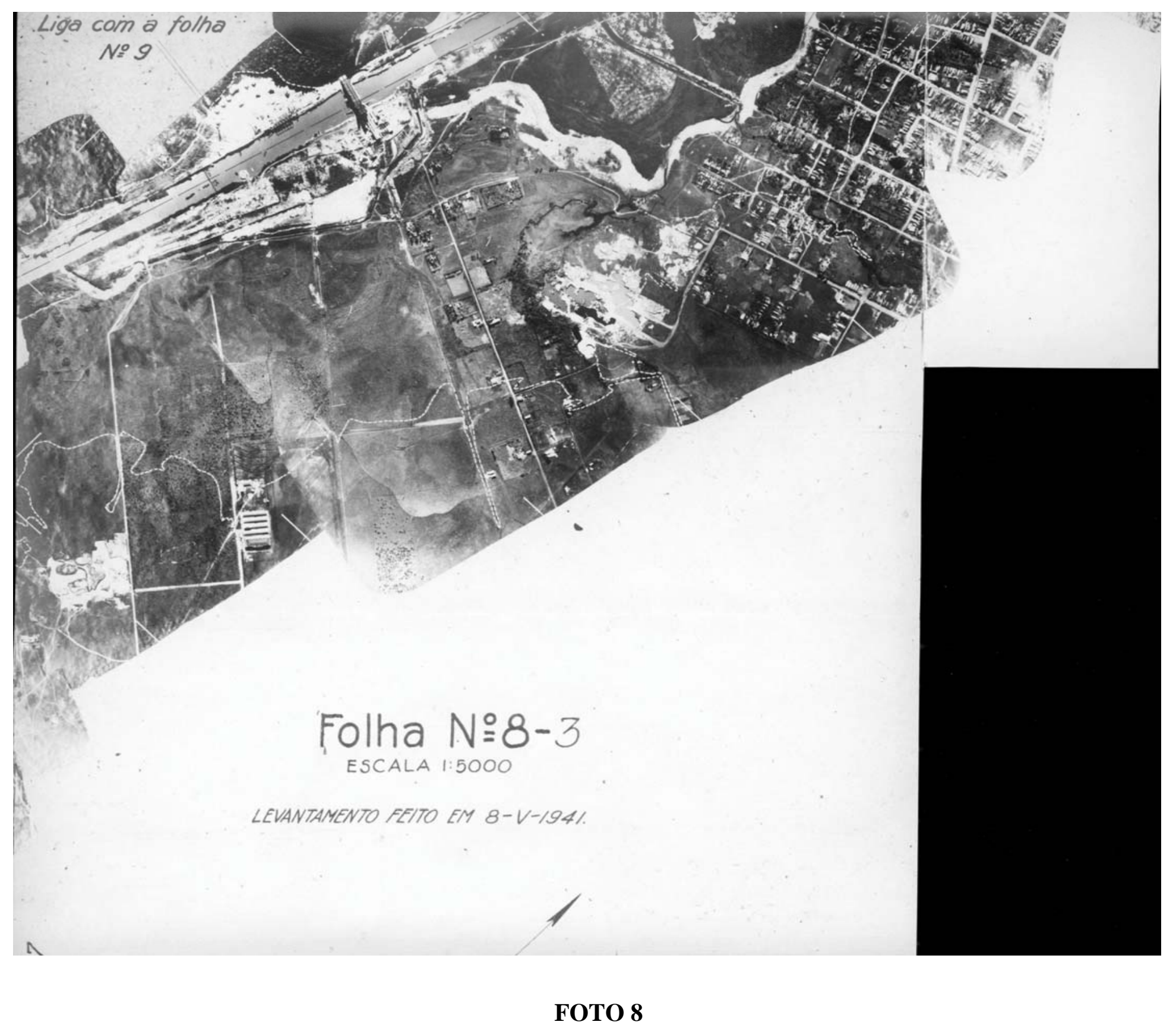




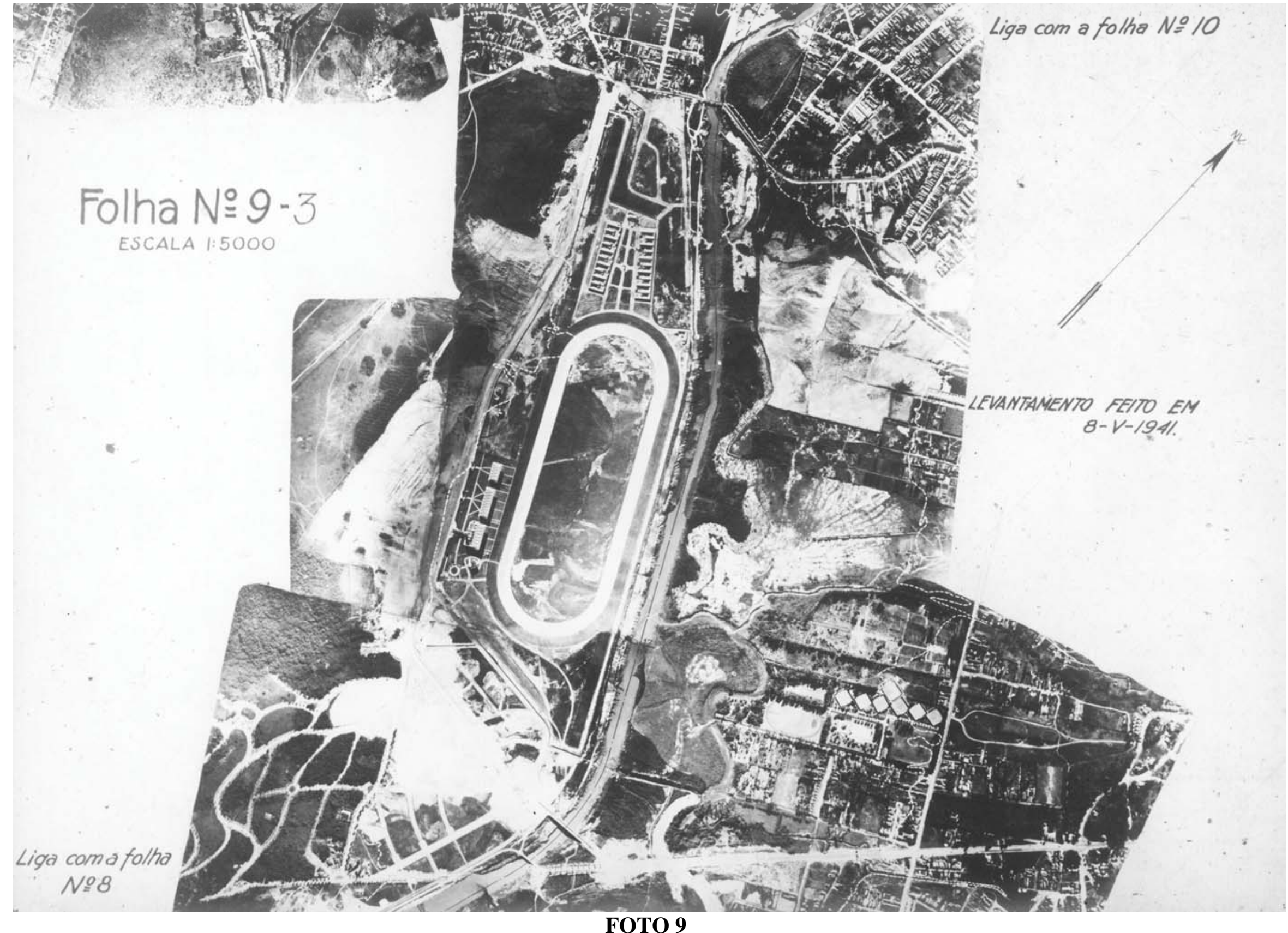




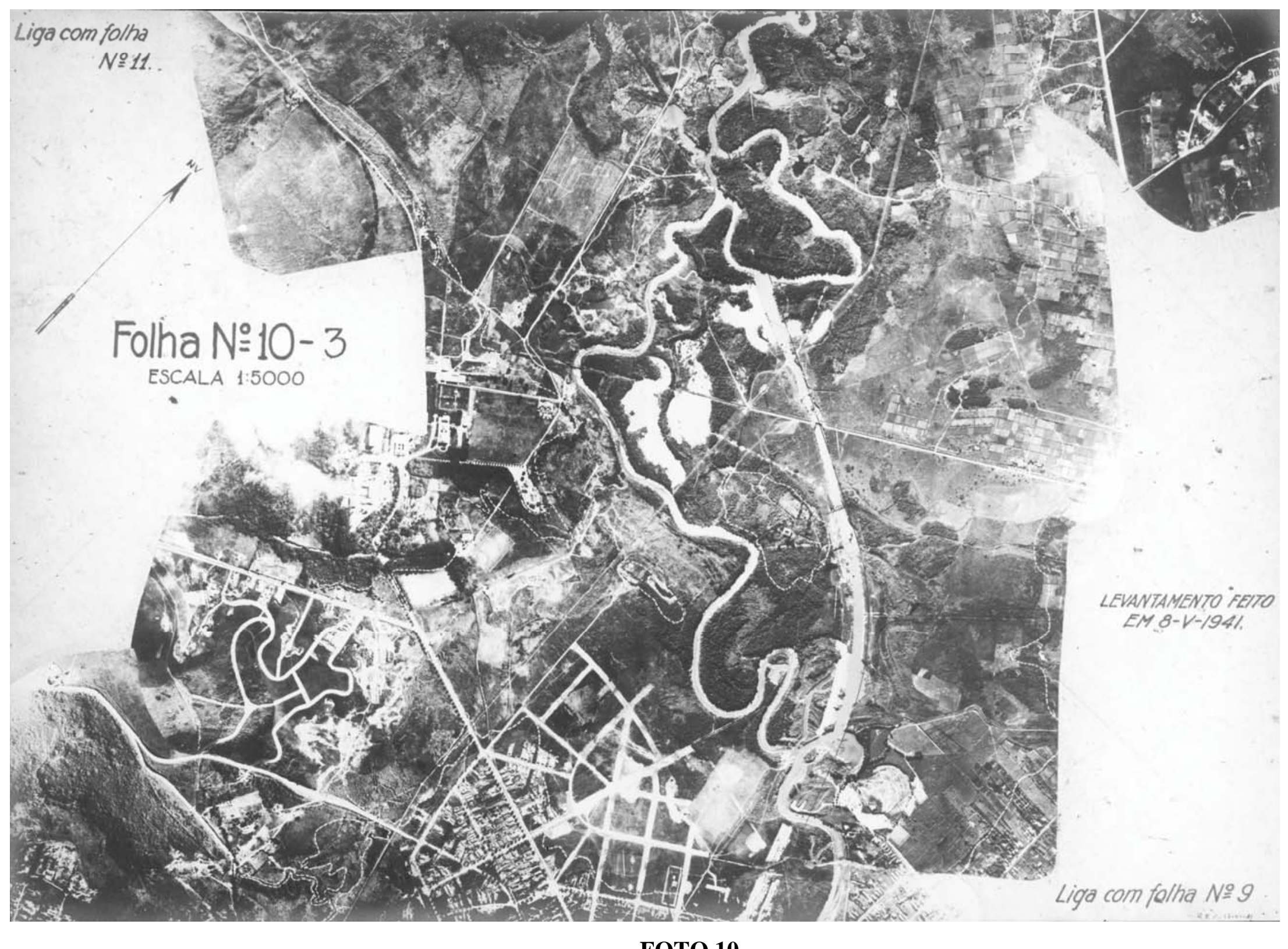

FOTO 10 


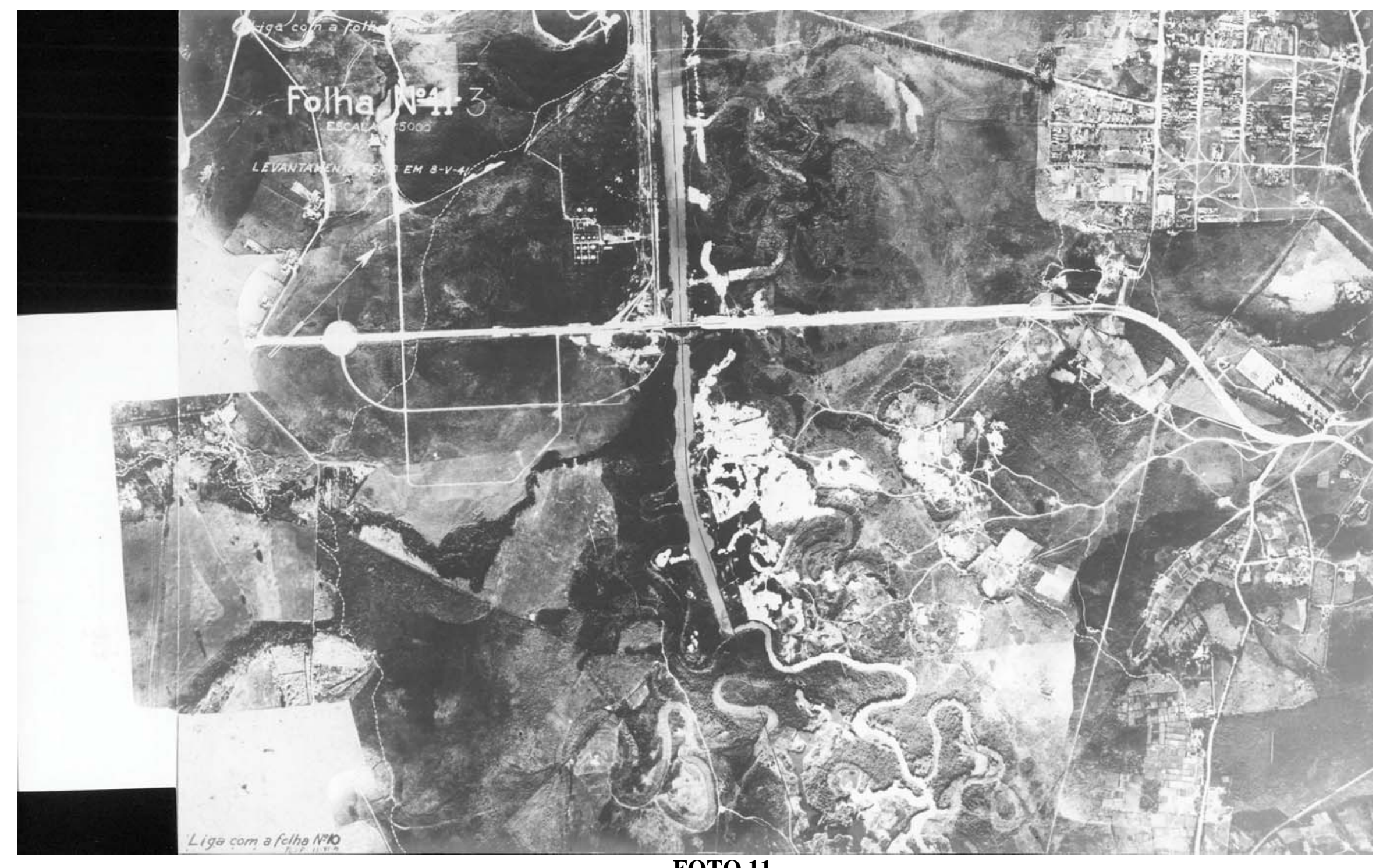




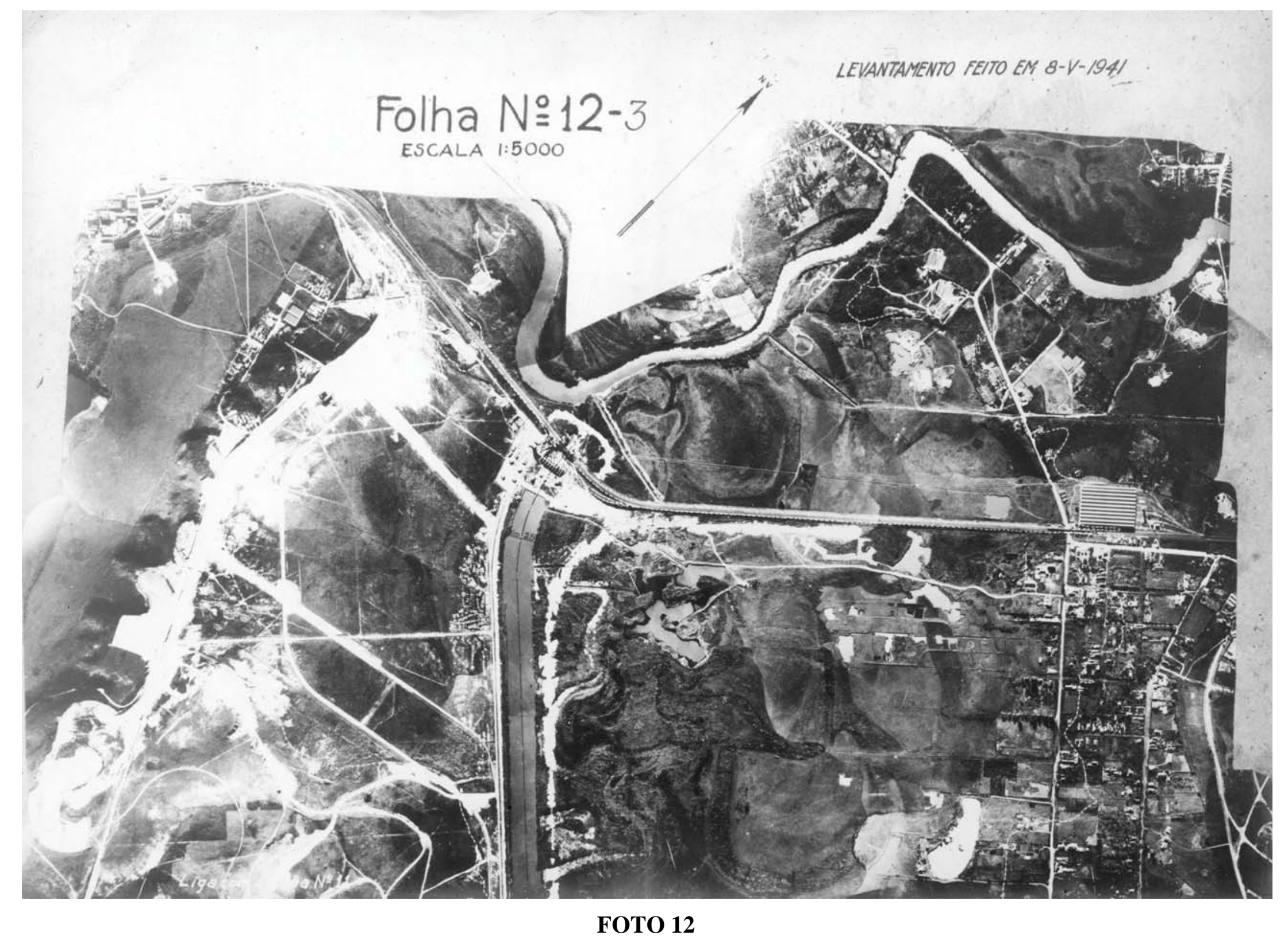


Todas estas etapas de delimitação das áreas inundáveis, implantação do canal e aproveitamento dos terrenos marginais estão excepcionalmente analisadas na referência (Seabra 1987); a autora, em Tese de Doutorado apresentada à Geografia da USP, destaca claramente que aos objetivos de geração hidroelétrica, foram acrescentados outros referentes à comercialização das vastas planícies aluvionais do Rio Pinheiros. Apoiando-se nos dados e conclusões desta tese, a edição de O Estado de São Paulo de 18 de fevereiro de 2001, em reportagem sob o título "O mistério da grande enchente de 1929" (Pontes 2001), descreve as negociações entre a Light e a City, relativamente ao critério da "linha de enchente", utilizado para definir os limites de abrangência das suas respectivas propriedades territoriais.

Em julho de 1950, entra em operação a última unidade geradora da Usina Hidroelétrica Externa de Cubatão, totalizando $474.000 \mathrm{~kW}$ de potência instalada.

Todavia, a última etapa de construção do complexo de geração hidroelétric da Light nas bacias do Alto Tietê e Cubatão, incluiria uma outra central de geração subterrânea em Cubatão. Esta etapa final foi autorizada pelo Decreto Federal $n^{\circ}$ 22.008, de 29 de outubro de 1946, permitindo elevação da Barragem de Santana do Parnaíba com instalação de conjuntos elevatórios reversíveis e a construção da Barragem de Pirapora no Rio Tietê, cerca de $10 \mathrm{~km}$ a jusante. Ressalte-se contudo, que o artigo $2^{\circ}$, parágrafo único estabelece que "as obras ora autorizadas não desobrigam a The São Paulo Tramway, Light and Power Co." de construir o reservatório do Alto Tietê e outros previstos no plano geral (ou seja, o Plano Hyde), a que se refere a legislação citada neste artigo, afim de serem regularizadas as descargas do Rio Tietê, quando se verificar necessária esta regularização, a juízo do Governo".

Concluída a implantação de todas as unidades do sistema de geração hidroelétrica do Alto Tietê e Cubatão, na forma dos esquemas em planta e perfil apresentados no Desenho 8, com barragem e nível d'água em Santana de Parnaíba elevados e a Usina Hidroelétrica Subterrânea em Cubatão implantada, o aproveitamento hidroelétrico permitiria direcionar o Rio Tietê para o Canal do Rio Pinheiros e deste para o 
Reservatório Rio Grande com o acionamento das Elevatórias de Traição e de Pedreira.

Conforme pode ser observado no Desenho 9, o Canal do Rio Pinheiros implantado, constitui o elo fundamental da reversão para viabilizar o aproveitamento hidroelétrico, com as características de planta, perfil e seções especificadas: $26 \mathrm{~km}$ de extensão, os trechos superior com $15.461 \mathrm{~m}$ e o inferior com10.083 m (além do Canal do Guarapiranga com $1.875 \mathrm{~m}$ ) e seções de canal trapezoidal de dimensões variáveis, com $40 \mathrm{~m}$ a $60 \mathrm{~m}$ de base e de 2 a $5 \mathrm{~m}$ de profundidade.

Esta reversão constituir-se-ia em impacto devastador sobre a qualidade das águas do Pinheiros e Reservatório Rio Grande (agora já chamado Reservatório Billings), tendo sido sucessivamente adiada por cerca de 5 anos até 1954.

Conforme Samuel Murgel Branco (Branco 1975), com a autorização para acionamento das Elevatórias de Traição e Pedreira em março de 1954, atendendo à demanda crescente por energia elétrica durante a grande seca 1953-1955, todos os 26 km de Canal do Rio Pinheiros tornaram-se poluídos pelas águas diluídas em esgoto in natura do Rio Tietê; além disso, estas águas bombeadas e descarregadas no Billings poluíam maciçamente suas águas, induzindo à formação de algas inicialmente em suas margens por terem águas menos profundas e em seguida em toda sua extensão, inviabilizando gradativamente todos os clubes náuticos ali existentes e todo o processo de urbanização apoiado na proximidade com águas abundantes e em ótima condição de qualidade.

Simultaneamente, durante o período desta grande seca, a Light inicia a operação da Usina Termoelétrica de Piratininga, com $450.000 \mathrm{~kW}$ de potência final.

Finalmente em 1961, é atingida a potência instalada final do sub-sistema de geração da agora São Paulo Light S/A. Serviços de Eletricidade, através da conclusão da usina subterrânea de Cubatão, com $390.000 \mathrm{~kW}$. Esta situação final, que permite aproveitar praticamente toda a vazão da Bacia do Alto Tietê, tem a potência instalada 


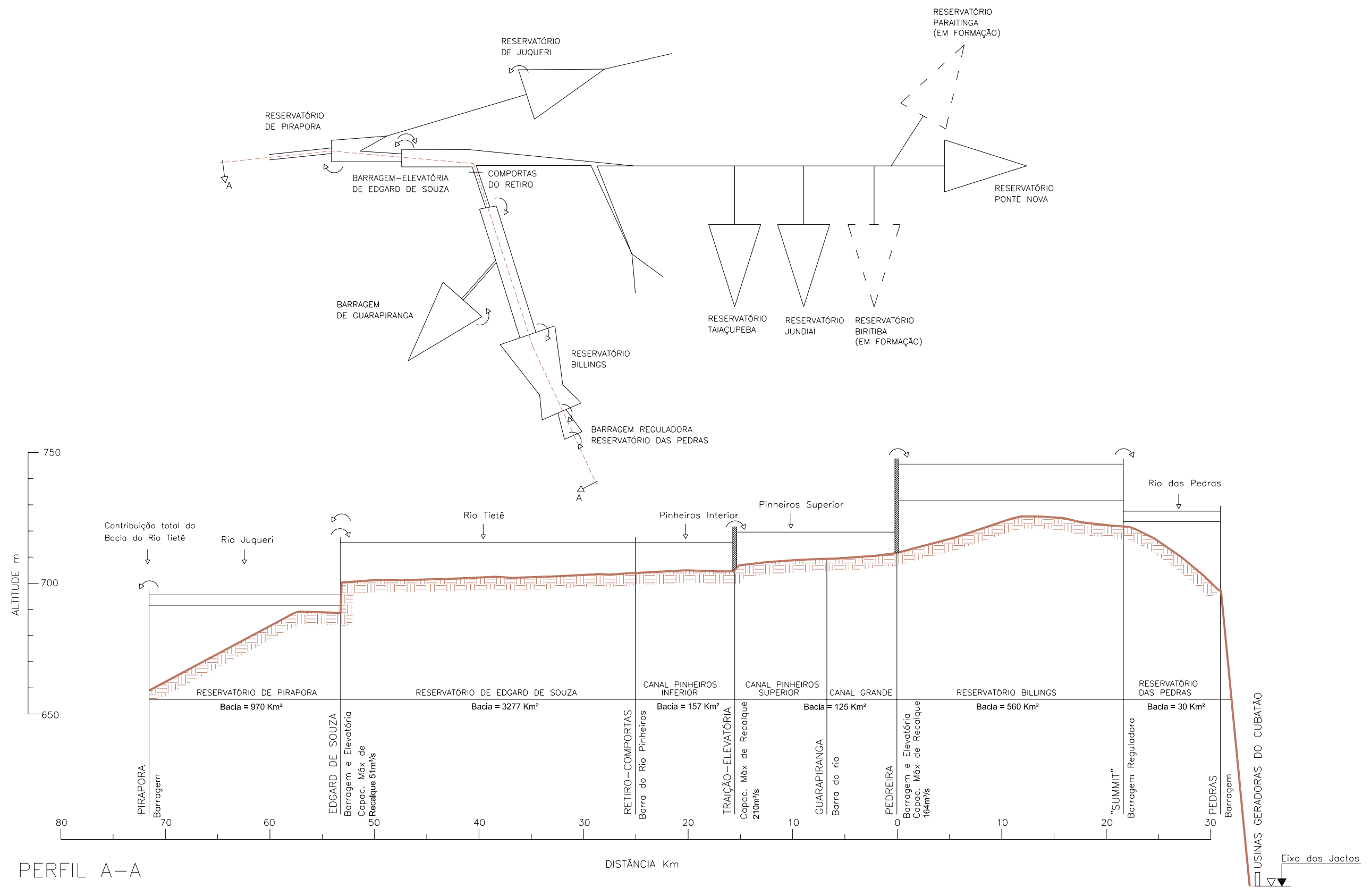



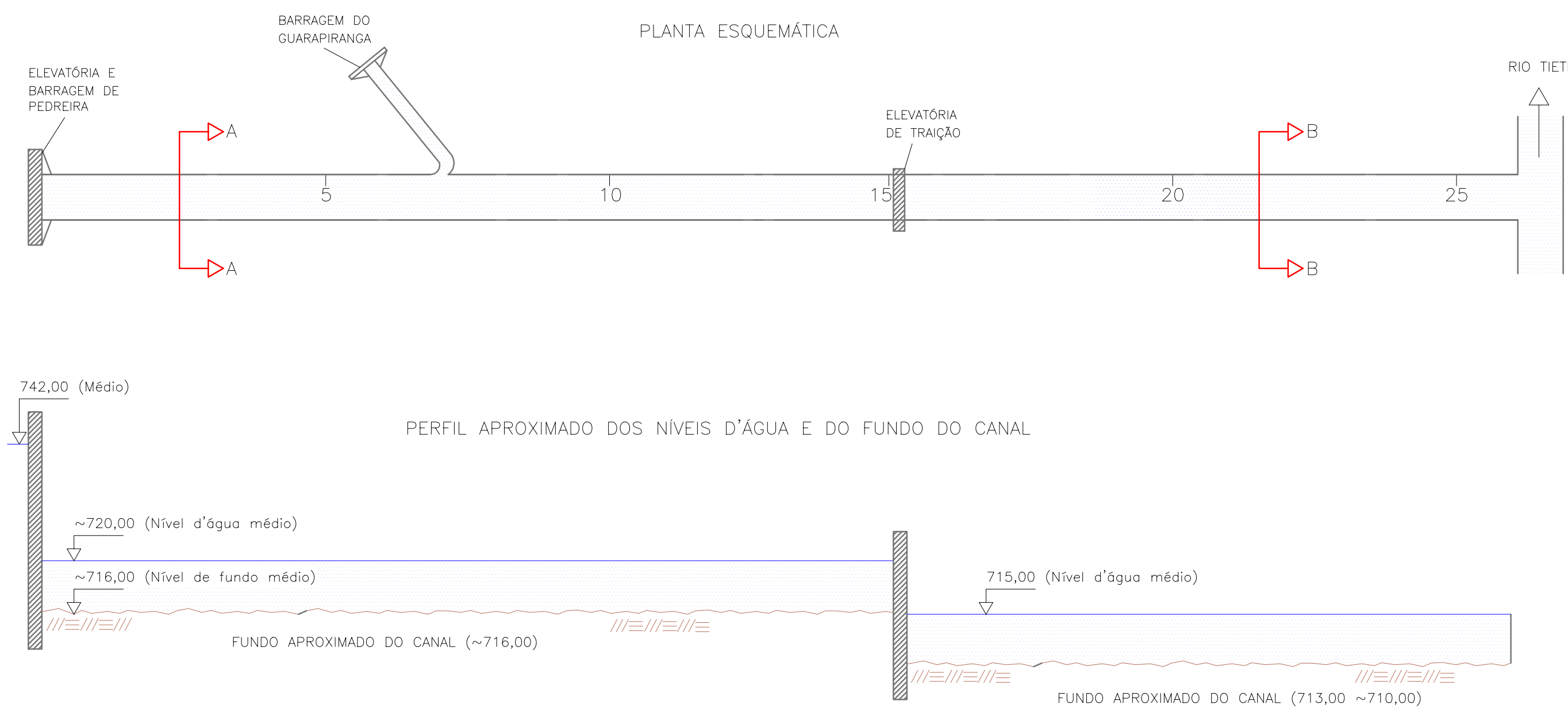

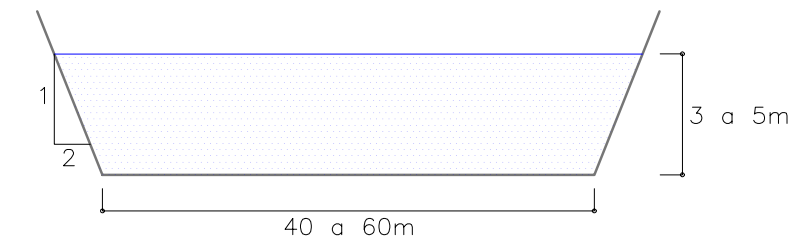

SEÇAO A-A (MÉDIA DAS SEÇÕES DO CANAL SUPERIOR)

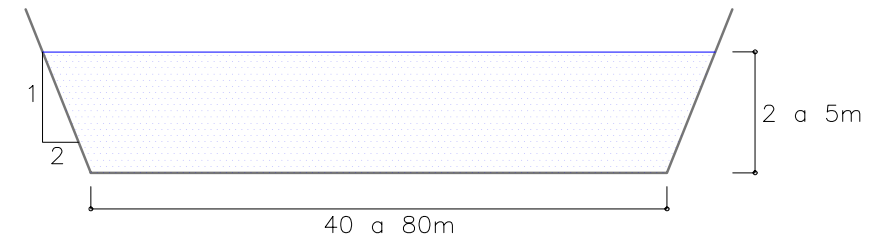

SEÇAO B-B (MÉDIA DAS SEÇÕES DO CANAL INFERIOR) 
de $946.000 \mathrm{~kW}$, dos quais $33.000 \mathrm{~kW}$ das usinas reversíveis de Santana do Parnaíba e Pedreira, e os restantes $933.000 \mathrm{~kW}$ das usinas de Cubatão.

\subsubsection{Situação Atual}

As obras seqüenciais que originaram o sub-sistema de geração hidroelétrica do Alto Tietê e Cubatão foram idealizadas visando otimizar o aproveitamento energético, atingindo este objetivo com notável eficiência.

Contudo, algumas restrições legais e constitucionais foram editadas, procurando ampliar os benefícios destes sub-sistemas e de suas estruturas constituintes para outros setores da comunidade, destacando-se a Região do ABC. Estas restrições estabelecem a possibilidade de bombeamento ao Reservatório Billings, apenas durante a ocorrência de enchentes severas nas bacias do Pinheiros e Tietê, quando os parâmetros de qualidade melhorariam em função da diluição dos esgotos.

Estas restrições legais encontram um quadro institucional muito diverso daquele existente durante a implantação do sub-sistema, pois com a privatização da distribuição de energia elétrica na área de concessão da ELETROPAULO, dando origem à empresa privada AES-Eletropaulo Metropolitana Ltda., foi constituída a empresa estatal estadual EMAE- Empresa Metropolitana de Águas e Energia, vinculada à Secretaria de Estado de Energia, Recursos Hídricos e Saneamento, que opera e mantém todo o sub-sistema, com objetivos múltiplos de controle de enchentes, geração de energia hidroelétrica em Cubatão, operação de serviços de transporte urbano com balsas em três trechos, nos braços de Bororé, Taquacetuba e João Basso do Reservatório Billings e navegação do Canal do Pinheiros restrita e estritamente necessária à sua limpeza e desassoreamento. 


\subsection{O SISTEMA RODOVIÁRIO AFETO À UTA CANAL DO RIO PINHEIROS}

No processo de estruturação de todos os sistemas viários servindo à região de São Paulo, o fato de grande relevância refere-se à situação de isolamento do Planalto Paulistano, imposto pelos obstáculos à transposição da Serra do Mar. Além deste aspecto, juntava-se outro não menos importante, ao adentrar-se o Planalto: deparavase com uma grande abundância de cursos d'água, obrigando os caminhantes a procurar os trajetos pelos divisores das águas, espigões e encostas, restringindo ao mínimo as transposições dos leitos dos rios e córregos, localizando-as criteriosamente apenas em pontos mais favoráveis.

Estas condições naturais do sítio de São Paulo determinaram a convergência de cinco grandes artérias de acessibilidade à Cidade de São Paulo, cujo "plano de ruas era polarizado pelo Caminho do Mar", que "abriam-se em leque para o interior: a nordeste ao longo do Rio Paraíba, para o Rio de Janeiro, ao norte para Minas Gerais, a noroeste para Campinas, a oeste-noroeste para Itu e Porto Feliz e a oeste para Sorocaba"(Morse 1970).

Destes caminhos, o caminho para oeste significou a primeira transposição rodoviária do Rio Pinheiros, a qual seguramente terminou por induzir à implantação do núcleo original do Bairro de Pinheiros, como ponto de parada no percurso entre São Paulo e oeste do Estado e como local de comércio e distribuição de produtos.

A partir do núcleo central de São Paulo, um caminho no sentido sudoeste para acesso à Itapecerica da Serra, também induziu ao surgimento do núcleo de Santo Amaro, por se constituir em local próximo à segunda travessia do Rio Pinheiros.

A partir desses núcleos iniciais de Pinheiros e Santo Amaro, próximos ao Rio Pinheiros, diversos empreendimentos rodoviários são implantados para garantir-lhes acessibilidade, promovendo um grande processo de disseminação de novos bairros, 
conforme (Mendes 1958) em primoroso capítulo do volume 3 - Aspectos da Metrópole Paulista, da coleção A Cidade de São Paulo em quatro volumes.

Neste capítulo intitulado Os Bairros da Zona Sul e os Bairros Ocidentais, são descritos os processos de crescimento dos bairros de Vila Mariana, Indianópolis, Brooklin e seus satélites, induzidos pela implantação de pequena estrada de rodagem, no início do século 20, hoje Av. Santo Amaro; dos bairros-jardins das vertentes do Pinheiros (Jardim América, Europa, Paulista, Paulistano, Cidade-Jardim), apoiados nos eixos das Rua Iguatemi e prolongamento da Rua Augusta; e dos bairros Pinheiros e Butantã, articulados por acessos às rodovias para oeste do Estado, que puderam induzir um processo de formação de diversos bairros (Vila Hamburguesa, Vila Leopoldina, Alto de Pinheiros, etc) e de implantação de novos equipamentos, destacando-se o CEAGESP e o Campus da USP.

Durante as décadas de 1970, 1980 e 1990, com a operacionalização de linhas de financiamento de urbanização de fundos de vale, no âmbito do SFS/BNH e CEF (Sistema Financeiro de Saneamento do Banco Nacional da Habitação, assumido pela Caixa Econômica Federal), inicia-se um processo vertiginoso de canalização de córregos afluentes ao Rio Pinheiros e de implantação de avenidas, associadas à implantação das marginais esquerda e direita do Pinheiros e das rodovias para oeste/sudoeste e para o litoral do Estado. Merecem destaque as articulações da Marginal Direita com as avenidas Roque Petroni e Vicente Rao/Córrego do Cordeiro, Bandeirantes/Córrego da Traição, Juscelino Kubitschek/Córrego do Sapateiro, Roberto Marinho/Córrego Águas Espraiadas e da Marginal Esquerda com as avenidas Eliseu de Almeida/Rio Pirajussara, Escola Politécnica/Córrego Jaguaré e Carlos Caldeira Filho/Córrego Morro do S.

Todo o sistema rodoviário nesta UTA foi implantado pelo Município de São Paulo, através da S.V.P. Secretaria de Vias Públicas, atual SIURB Secretaria de Infraestrutura Urbana, sendo mantido pelo conjunto de 10 sub-prefeituras do Município de São Paulo: Lapa, Butantã, Pinheiros, Vila Mariana, Santo Amaro, Jabaquara, Cidade Ademar, Campo Limpo, M’Boi Mirim e Capela do Socorro. 
A operação do tráfego nas Marginais do Pinheiros e Av. Bandeirantes é subordinada à Gerência de Engenharia de Tráfego 6(GET 6), da Companhia de Engenharia de Tráfego(CET), vinculada à Secretaria Municipal dos Transportes(SMT). Segundo os dados médios disponíveis, registra-se uma movimentação média de 450.000 veículos por dia nestas marginais, com pico da manhã na Marginal Esquerda no trecho Cebolão até acesso à Av. dos Bandeirantes e na Marginal Direita das Pontes do Morumbi até a Ponte Eusébio Matoso. Constata-se também um movimento de pedestres significativo, da ordem de 500 a 1000 por hora em horários de pico da manhã, nas travessias das pontes Cidade Universitária, Eusébio Matoso e Cidade Jardim.

O Desenho 10 anexo traz as localizações dos principais referenciais viários da UTA, como pontes, marginais, túneis etc. 


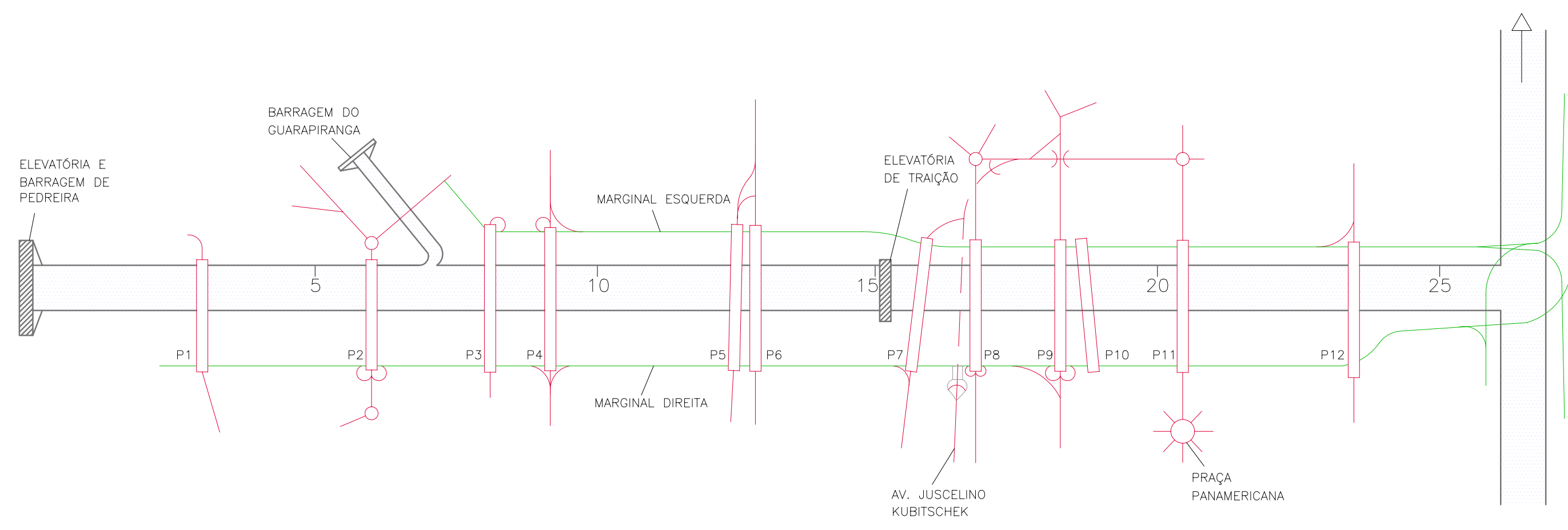




\subsection{O SISTEMA FERROVIÁRIO AFETO À UTA CANAL DO RIO PINHEIROS}

Segundo Richard Morse (Morse 1970), menos de uma década depois de implantada a Estrada de Ferro Santos-Jundiaí (São Paulo Railway Co.), cinco ferrovias já estavam em funcionamento, fazendo com que a extensão dos trilhos no entorno da Cidade de São Paulo passasse de $139 \mathrm{~km}$ em 1870 para $2425 \mathrm{~km}$ em1890.

A Estrada de Ferro Sorocabana (EFS) foi implantada na direção oeste, a partir do Bairro dos Campos Elíseos, na área central da Cidade de São Paulo, estendendo-se à Sorocaba em 1875, à Ipanema em 1875 e à Tietê em 1883.

Na direção sudoeste, também foi implantada, entre 1883 e1886, uma estrada de ferro com carros a vapor, ligando o núcleo central de São Paulo a Santo Amaro, a qual deve ter sido desativada duas décadas depois (Mendes 1958).

Em 1927, a Estrada de Ferro Sorocabana inicia sua operação de trens de subúrbio.

Concluída a canalização do Rio Pinheiros em meados da década de 1940, surge a possibilidade de implantar novo trecho da Sorocabana às margens do canal, iniciando o ramal em Osasco/Presidente Altino, transpondo o canal próximo à Vila Leopoldina, percorrendo a margem direita até Santo Amaro, onde novamente cruzaria o canal para o Bairro de Interlagos, seguindo aproximadamente pelo divisor entre as bacias dos Reservatórios Billings e Guarapiranga, conectando-se ao Porto de Santos .

A implantação deste trecho somente foi iniciada com o final da concessão da São Paulo Railway em 1946, quando cessa o veto à construção de outra estrada de ferro em distância inferior a $60 \mathrm{~km}$ da Cidade de São Paulo. Neste ano, a EFS inicia a construção da "variante entre as estações Presidente Altino e Santos, pela margem direita do Canal do Rio Pinheiros”, concluída em 1956 (ANTP 1997), para transporte de carga e passageiros. 
A empresa estatal estadual Ferrovias Paulistas (FEPASA), é constituída em 1971, assumindo a operação e modernização deste trecho. Durante as décadas de 1970 e 1980, são reinauguradas diversas estações (CEASA, Cidade Universitária, Jaguaré e Pinheiros) e implantadas estações Largo Treze e Jurubatuba.

Mais recentemente, em 1993, com a constituição da Companhia Paulista de Trens Metropolitanos(CPTM), esta assume gradualmente as linhas de passageiros da FEPASA e da Companhia Brasileira de Trens Urbanos (CBTU, vinculada ao Ministério dos Transportes).

A partir de 1996, com a unificação do Trem Metropolitano e sua incorporação ao patrimônio da CPTM, iniciou-se a implantação de um grande projeto que envolveu a construção de 7 novas estações nas margens do Canal do Pinheiros (HebraicaRebouças, Cidade-Jardim, Vila Olímpia, Berrini, Morumbi, Granja Julieta e Socorro), a aquisição de nova frota de trens, etc conferindo alto padrão de qualidade aos serviços prestados.

Não obstante tais predicados, a Linha $C$ transporta em média atualmente cerca de 60 mil passageiros por dia, muito aquém da sua capacidade operacional.

A CPTM também acaba de concluir as obras e montagens e iniciar a pré-operação da Linha Largo 13-Capão Redondo, que deverá ser operada pelo METRÔ neste trecho, a quem caberá sua ampliação posteriormente desde Largo 13 até Estações Santa Cruz e Chácara Klabin, completando toda a extensão da Linha 5 planejada.

O METRÔ também inicia, no primeiro semestre de 2004, a implantação de toda a Linha 4 Luz-Vila Sônia e das estações de conexão Luz, República, Paulista, Pinheiros (articulada com Estação Pinheiros da CPTM) e Butantã, para atendimento de uma demanda aproximada de 900 mil passageiros por dia.

O Desenho 11 anexo explicita esquematicamente o sistema ferroviário afeto à UTA. 


\subsection{O SISTEMA ESGOTOS AFETO À UTA CANAL DO RIO PINHEIROS}

Todas as bacias de esgoto da Bacia do Alto Tietê e as cinco respectivas unidades de tratamento, configuram os cinco sistemas integrados da Região Metropolitana: Barueri, ABC, Parque Novo Mundo, São Miguel e Suzano. Todos estes sistemas são objeto de um vasto programa operacional e de obras para despoluição dos Rios Tietê, Pinheiros, Tamanduateí e demais corpos d'água da Região Metropolitana de São Paulo, em implementação pela SABESP desde a década de 1980.

As 32 bacias de esgoto contribuintes à UTA Canal do Rio Pinheiros fazem parte do Sistema Barueri, o qual abrange toda a região oeste metropolitana e parte de sua área central.

Os índices de atendimento por coleta nestas 32 bacias variam de $40 \%$ a $100 \%$, com índice de atendimento total médio de $85 \%$, com cerca 810 mil usuários ativos com oferta do serviço, acrescidos de cerca de 123 mil de ligações em favela.

Quanto aos índices de atendimento por coletores-tronco e por interceptores ao longo dos $26 \mathrm{~km}$ do canal, deve-se ressaltar que atualmente todas as bacias afluentes ao Pinheiros Inferior tem coletores-tronco e interceptores implantados e em operação; no Pinheiros Superior, apenas cerca de $40 \%$ dos usuários são interceptados.

Este quadro de desequilíbrio entre as ofertas de coleta e de interceptação, deverá mudar brevemente na UTA Canal do Pinheiros, em função do estágio avançado das obras dos grandes interceptores 5 e $\mathbf{6}$ em andamento, com conclusão prevista para 2005. Somente com o início de suas operações e o encaminhamento dessa parcela da contribuição dos esgotos da bacia à ETE de Barueri, pode-se afirmar que deverá ser constatada uma melhoria sensível na qualidade das águas em trechos do Canal. Esta melhoria, se for associada ao bom desempenho dos sistemas de varrição de ruas, de coleta de resíduos sólidos e períodos de chuvas regulares, permitirá seguramente a 


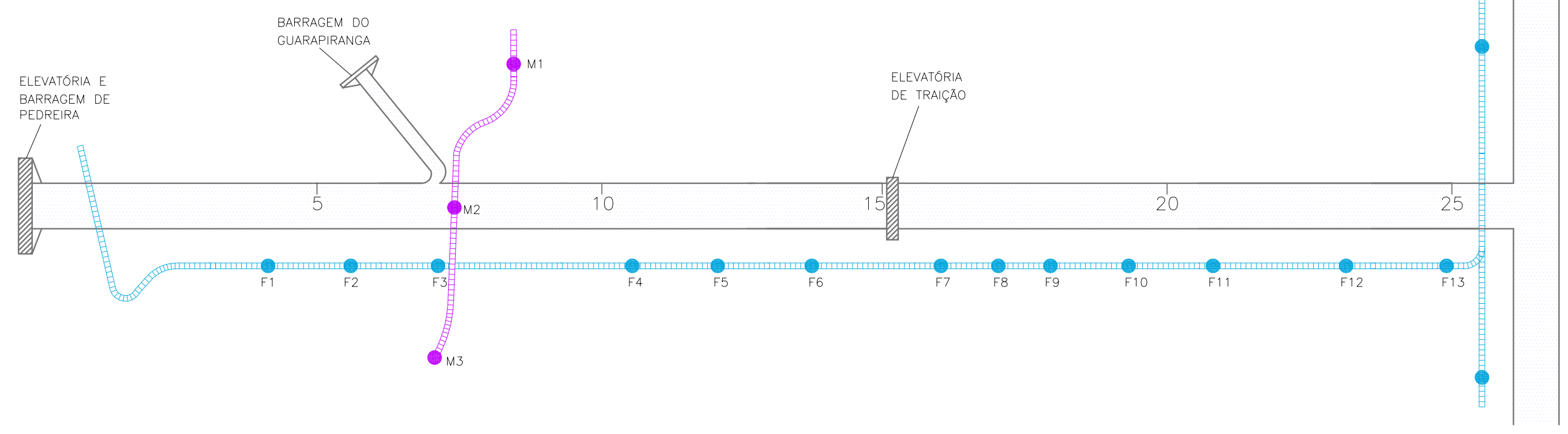

\begin{tabular}{|c|c|}
\hline $\begin{array}{l}\text { ESTACOOES FERROVIÁRIAS } \\
\text { (LINHA C) }\end{array}$ & $\begin{array}{l}\text { ESTACOOES METROVIÁRIAS } \\
\text { (LINHA 5) }\end{array}$ \\
\hline $\begin{array}{l}\text { F1 - JURUBATUBA } \\
\text { F2 - SOCORRO } \\
\text { F3 - SANTO AMARO } \\
\text { F4 - GRANJA JULIETA } \\
\text { F5 - MORUMBI } \\
\text { F6 - BERRINI } \\
\text { F7 - VILA OLIMPIA } \\
\text { F8 - CIDADE JARDIM } \\
\text { F9 - HEBRAICA-REBOUÇAS } \\
\text { F10 - PINHEIROS } \\
\text { F11 - CIDADE UNIVERSITARIA } \\
\text { F12 - VILLA LOBOS -JAGUARE } \\
\text { F13 - CEASA }\end{array}$ & $\begin{array}{l}\text { M1 - GIOVANNI GRONCH } \\
\text { M2 - SANTO AVARO } \\
\text { M3 - LARGO TREZE }\end{array}$ \\
\hline
\end{tabular}


ausência de cheiro oriundos de compostos de enxofre e provavelmente a presença de algumas espécies de peixes.

Deve-se ressaltar a importância dos índices de desempenho operacional da estações de tratamento da Sabesp especialmente de Barueri, que poderão manter padrões de qualidade de água adequados e predeterminados nos vários trechos do Canal.

Um fator relevante que pode perturbar os padrões de qualidade das águas nesta UTA, refere-se ao sub-sistema coleta de esgotos em cerca de 120 mil favelas. Neste aspecto, a única alternativa consiste em dotá-las dessas redes, articulando-as com metas de salubridade ambiental viáveis, legitimadas pela comunidade e governos e avaliadas permanentemente.

O Desenho 12 representa esquematicamente os sub-sistemas de coleta e interceptação de esgotos na UTA. 


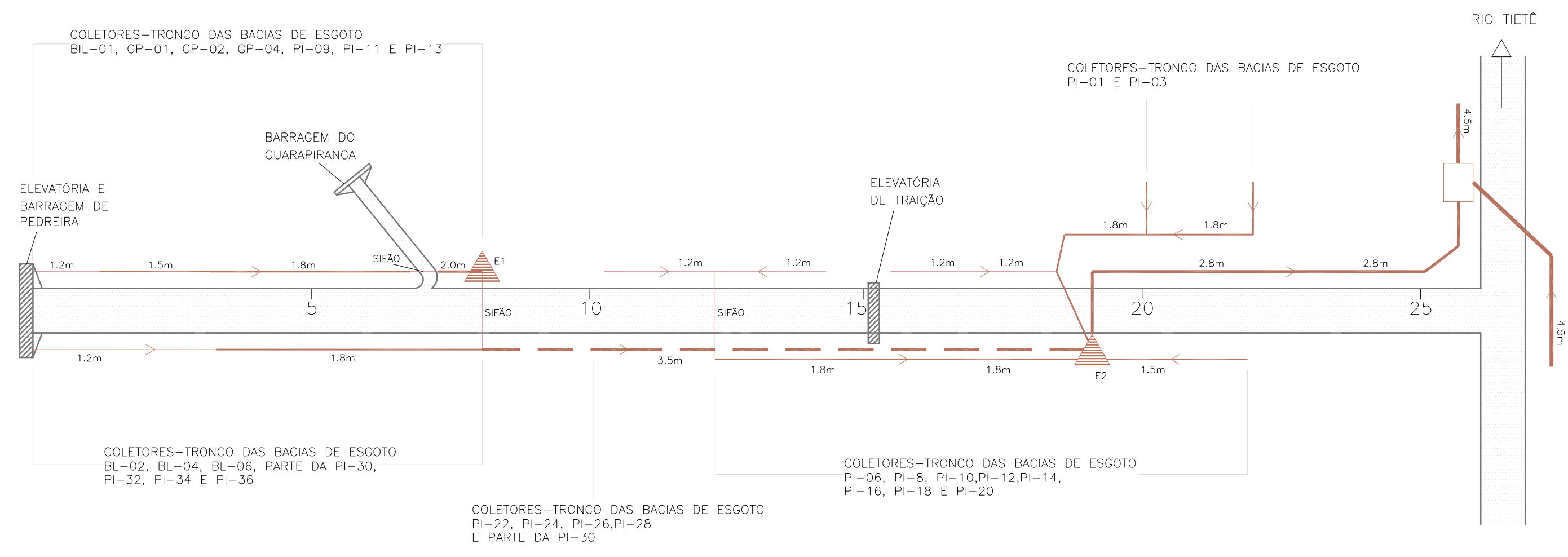




\subsection{O SISTEMA RESÍDUOS SÓLIDOS AFETO À UTA CANAL DO RIO PINHEIROS}

O Sistema de Resíduos Sólidos afeto ao Canal do Rio Pinheiros está relacionado às atribuições dos Municípios de São Paulo, e em menor escala, dos municípios de Taboão da Serra e Embu das Artes, como responsáveis pela administração e controle dos serviços de limpeza pública nos seus territórios, e também à EMAE - Empresa Metropolitana de Águas e Energia, como operadora e mantenedora do sub-sistema usinas geradoras de energia elétrica. Acrescente-se que às administrações municipais também compete gerir o uso e ocupação do solo, o que implica na suas responsabilidades institucionais no controle dos processos de erosão, perda de solo, instabilidade de encostas, assoreamento dos fundos de vale e perda das capacidades de escoamento dos canais.

Desta forma, a descrição da situação atual e avaliação do desempenho do Sistema de Resíduos Sólidos considera inicialmente os sistemas de limpeza pública municipais e em seguida os serviços de dragagem para desassoreamento do canal, a cargo da EMAE.

\subsubsection{Os Sistemas de Limpeza Pública Municipais}

Embora pequena parcela do território de Embu e a quase totalidade de Taboão da Serra façam parte das cabeceiras da Bacia do Rio Pirajussara, considera-se a situação predominante do Município de São Paulo, como determinante principal para caracterizar e avaliar os sistemas municipais.

De fato, São Paulo tem um vasto território para coleta e instalações de grande porte na área da UTA, que estão atualmente em operação mas que deverão ser modificadas no seu formato operacional, pois terão contratos de concessão pelo prazo de 20 anos (e não mais por empreitada), renováveis por igual período, com pagamento por toneladas de resíduos coletados. 
Toda a UTA fará parte do bloco noroeste de concessão, um dos 2 blocos em que foi dividido o município, abrangendo 13 subprefeituras. Os 2 blocos deverão ter área para implantação de novos aterros sanitários, prever usinas de compostagem e garantir a universalização dos serviços, com coleta porta a porta em favelas.

Deverão ser implantadas novas formas de operar a varrição, a coleta predial e a destinação final, as quais deverão ter repercussões positivas na UTA, por homogeneizar os procedimentos e remunerar a concessionária por produção, promovendo a eficiência dos serviços e evitando a situação atual,onde se verifica o carreamento de lixo não varrido e/ou não coletado ao Canal. Ressalte-se também a necessidade das concessionárias explicitarem metas de desempenho para as favelas, as quis deverão ter seus serviços apoiados por programas em educação ambiental, coleta seletiva, etc.

\subsubsection{O Sub-sistema Dragagem para Desassoreamento do Canal do Pinheiros}

Com base na referência (Sartori e Nascimento,2003), foi possível dispor de uma descrição extremamente acurada dos trabalhos desenvolvidos pela EMAE para manutenção das seções do Canal. Cabe aqui destacar os seguintes aspectos, julgados mais relevantes, para esta análise de situação e desempenho.

"Para manter a calha do Canal e a região próxima às elevatórias em condições operacionais adequadas, visando o controle de cheias, são realizados constantemente os serviços de dragagem."

“A caracterização desse sedimento-realizada no início da década de 90-constatou que dos materiais desassoreados, aproximadamente 95\% em peso corresponde a sedimentos e 5\% a resíduos sólidos diversos." 
“...a EMAE decidiu adotar, a partir de 2001, um plano de monitoramento do material de assoreamento do Canal do Rio Pinheiros, com a realização de três campanhas anuais de Coleta, Análises Laboratoriais e Classificação do Material, com o objetivo de obter subsídios para a elaboração de proposta de procedimentos, para a disposição final desse material, a ser apresentada à Secretaria de Meio Ambiente do Estado de São Paulo (SMA) e à CETESB - Companhia de Tecnologia de Saneamento Ambiental."

Os autores descrevem três formas como são realizados os serviços de dragagem.

Na primeira forma, "os serviços consistem na utilização de equipamentos dotados de bomba de sucção e recalque..." dispondo o material em terrenos laterais ao Canal, denominados bota-fora. "Os serviços são efetuados através de recursos próprios e contratados, envolvendo retirada média anual de cerca de $400.000 \mathrm{~m}^{3}$ de material de assoreamento (média dos últimos 5 anos), sendo que os bota-foras utilizados são aqueles de propriedade da EMAE.

”Na segunda forma "os serviços compreendem à utilização de escavadeiras mecânicas de grande porte, que ficam locadas junto aos principais córregos contribuintes, escavando o material de assoreamento, depositando-o na margem do Canal e, após um período de secagem, o seu carregamento e transporte, por intermédio de caminhões, para a área de disposição final. Os serviços são efetuados através de recursos contratados, envolvendo uma retirada média mensal de assoreamento de $15.000 \mathrm{~m}^{3}$, referentes aos córregos Jaguaré, Pirajussara, Brooklin e Morro do "S", sendo que o licenciamento da área de disposição final tem sido de responsabilidade da contratada.

A terceira forma de dragagem "utiliza uma plataforma flutuante, na qual está instalada uma escavadeira hidráulica, e uma barcaça auto-propulsora. Uma vez carregada, a barcaça navega em direção aos locais onde estejam localizados os demais equipamentos de desassoreamento (draga e/ou escavadeira junto aos córregos), para que os mesmos possam fazer a retirada definitiva do material.Esse 
sistema também atua nos serviços de retirada mecânica de vegetação aquática e emergente, ao longo do canal e no controle da proliferação de larvas de mosquitos em uma ação conjunta com a PMSP.”

"O material de assoreamento (mistura de água e sedimentos) no bota-fora, sofre um processo de decantação e drenagem, e após um período de secagem, são executados os serviços de terraplenagem, adequando-o para novos recebimentos de material de assoreamento, e assim sucessivamente, promovendo o ciclo de aterro e desaterro.”

A conclusão apresentada pelos autores, embora positiva, levanta sérias preocupações acerca da sustentabilidade de procedimentos operacionais e de manutenção intermitentes, que já deveriam contar com normas rotineiras e permanentes, mercê da vasta experiência da EMAE e de sua predisposição para adoção de procedimentos ambientalmente adequados.

O Desenho 13 procura avaliar, em bases estimativas, quais são os trechos do canal que sofrem um processo mais acentuado de deposição de materiais e qual é a participação percentual desses trechos no total de material sedimentado. Além disso, são sugeridas tendências de aumento ou diminuição dos aportes de sedimentos nesses trechos, em função das diferentes situações de áreas remanescentes passíveis de urbanização, em cada bacia contribuinte afluente ao canal. 


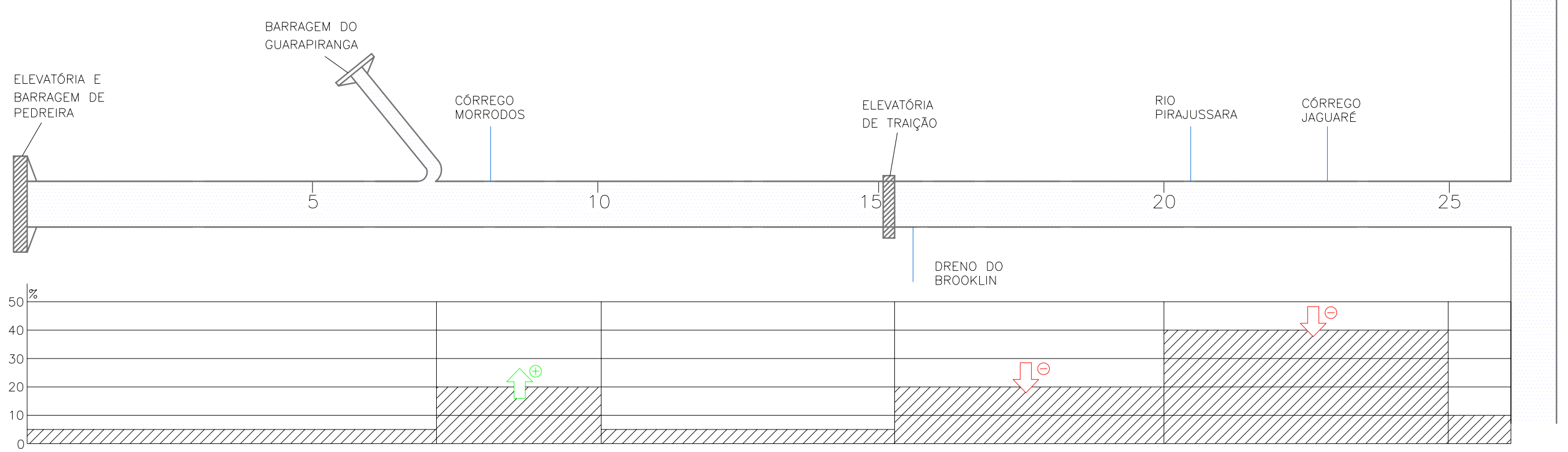

ESTIMATIVA DA DISTRIBUIÇÃO DO MATERIAL DRAGAdO (POR TRECHOS DO CANAL E AVALIAÇÃO DE TENDENCIA, CONSIDERANDO

A CONTRIBUIÇAO DOS AFLUENTES AO CANAL, SEM CONTRIBUIÇAO SIGNIFICATIVA DO RIO TIETE. 


\subsection{O SISTEMA DRENAGEM AFETO À UTA CANAL DO PINHEIROS}

Praticamente todos os cursos d'água contribuintes ao Pinheiros receberam canalizações em trechos ou na totalidade do seu percurso, associadas às avenidas projetadas para trânsito rápido.

Para descrição e avaliação da situação atual do Sistema Drenagem, considerou-se necessário analisar alguns dos principais contribuintes ao Canal do Pinheiros: Rio Pirajussara, Córrego do Sapateiro e Córregos Traição, Águas Espraiadas e Cordeiro, afluentes ao Dreno do Brooklin.

Merecem destaque particularmente o Córrego do Sapateiro e o Dreno do Brooklin, por se constituírem em duas concepções opostas de ocupação das várzeas e das margens dos cursos d'água.

Os formadores do Sapateiro foram represados, dando origem aos lagos do Parque do Ibirapuera, regularizando as cheias de uma bacia atualmente muito urbanizada, aumentando significativamente a segurança às enchentes nas avenidas de fundo de vale a jusante do Parque (avenidas Juscelino Kubitschek e Moura Andrade).

As bacias do Dreno do Brooklin e dos seus contribuintes, por sua vez, aumentam sobremaneira os riscos de ocorrência de enchentes ao longo da Avenida Berrini, por ter sido implantado um canal-interceptor (o dreno), para receber as contribuições de três bacias, as quais anteriormente eram tributárias diretas do Pinheiros, em trechos com muitos meandros. Além disso, cuidou-se apenas de prover um canalreservatório de concreto para acumulação de cheias (piscinão), no médio curso do Córrego Águas Espraiadas e uma elevatória no seu trecho final, para recalcar as cheias afluentes do Córrego Cordeiro, diretamente ao Canal do Pinheiros Superior. 


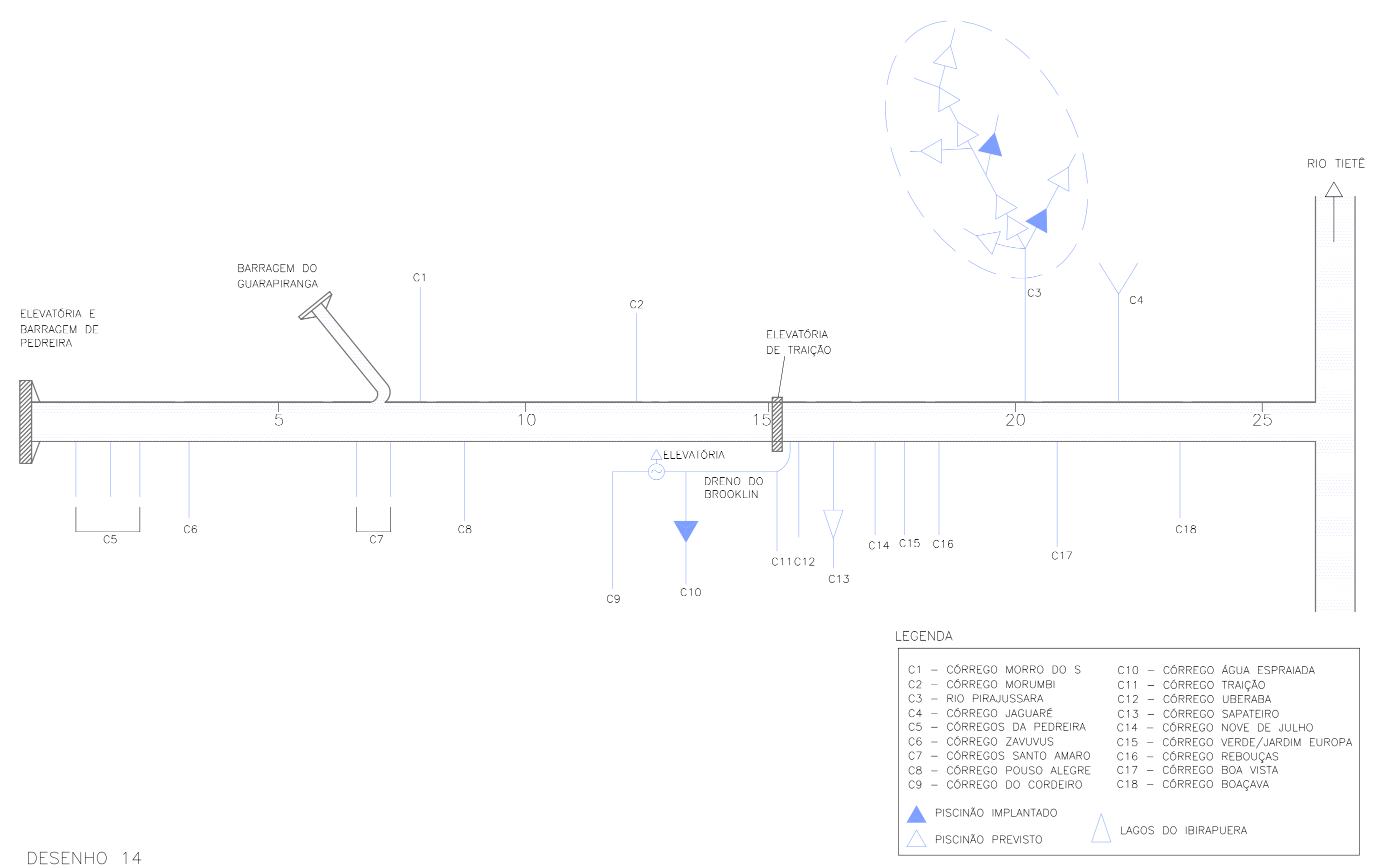


Estão sendo implantados "piscinões" em diversos afluentes do Pirajussara, com apenas dois em funcionamento de um conjunto total previsto de dez, implantados em seu alto curso.

Todos os demais 14 cursos d'água, conforme pode ser observado no Desenho 14, estão total ou parcialmente canalizados, o que torna a operação de controle de enchentes no Canal do Pinheiros de grande complexidade.

Desta forma, para operação de controle de cheias na Bacia do Rio Pinheiros, e especialmente no Canal, a responsabilidade institucional é da EMAE, que administra o COS Centro de Operação do Sistema, com autorização para bombear ao Reservatório Billings, apenas em situações de emergência, quando existir possibilidade de ocorrência de extravasamento em alguns pontos baixos da margem direita do Canal Inferior. 


\subsection{AVALIAÇÃO DA PROPOSIÇÃO NO QUADRO GERAL DOS SISTEMAS DE INFRA-ESTRUTURA NA UTA CANAL DO PINHEIROS}

A implantação gradativa do sub-sistema "usinas geradoras" de eletricidade, aproveitando o potencial hidroelétrico da interligação das bacias hidrográficas do Alto Tietê em São Paulo (vertente continental) e do Cubatão na Baixada Santista (vertente marítima), implicou na necessidade de implantar sucessivamente os subsistemas "barragens" e "cursos d'água naturais canalizados" relacionados ao grupo Hídrico e dos sub-sistemas "pontes”, “canais navegáveis", “eclusas” e "portos” para tráfego, navegação e manutenção dos canais, relacionados ao grupo Viário. Em relação à implantação dos sub-sistemas "canal navegável” e "curso d’água natural canalizado", está-se referindo ao Canal do Rio Pinheiros com cerca de $26 \mathrm{Km}$ de extensão, situado a oeste do Município de São Paulo, utilizado desde a década de 1950 para reverter praticamente toda a vazão da Bacia do Alto Tietê para o Reservatório e as Billings e unidades de geração hidroelétricas de Cubatão e atualmente somente operado para controle de enchentes e navegação de limpeza e desassoreamento do canal.

A avaliação geral dos sistemas de infra-estrutura Geração de Energia Elétrica, Sistema Rodoviário, Sistema Ferroviário, Sistema de Esgotos, Sistema de Resíduos Sólidos e Sistema de Drenagem, feita no âmbito estrito da UTA, considerou a possibilidade de expansão de seus limites de análise apenas para uma melhor compreensão das características intrínsecas de cada sistema, conforme pode ser observado no Desenho 15 - Esquema Geral do Canal do Rio Pinheiros.

Este raciocínio de expansão pode ser aplicado ao sub-sistema de Geração de Energia Hidroelétrica, implicando num primeiro nível de ampliação da análise: o fluxo da água, que pode perpassar os limites da UTA, demonstra com isso a interdependência da UTA Canal em relação ao Rio Tietê e à Bacia do Rio Cubatão, quanto ao aspecto fluxo de água. O mesmo raciocínio, também pode ser aplicado ao sub-sistema linhas de transmissão de energia elétrica em alta tensão, resultando num segundo nível de 


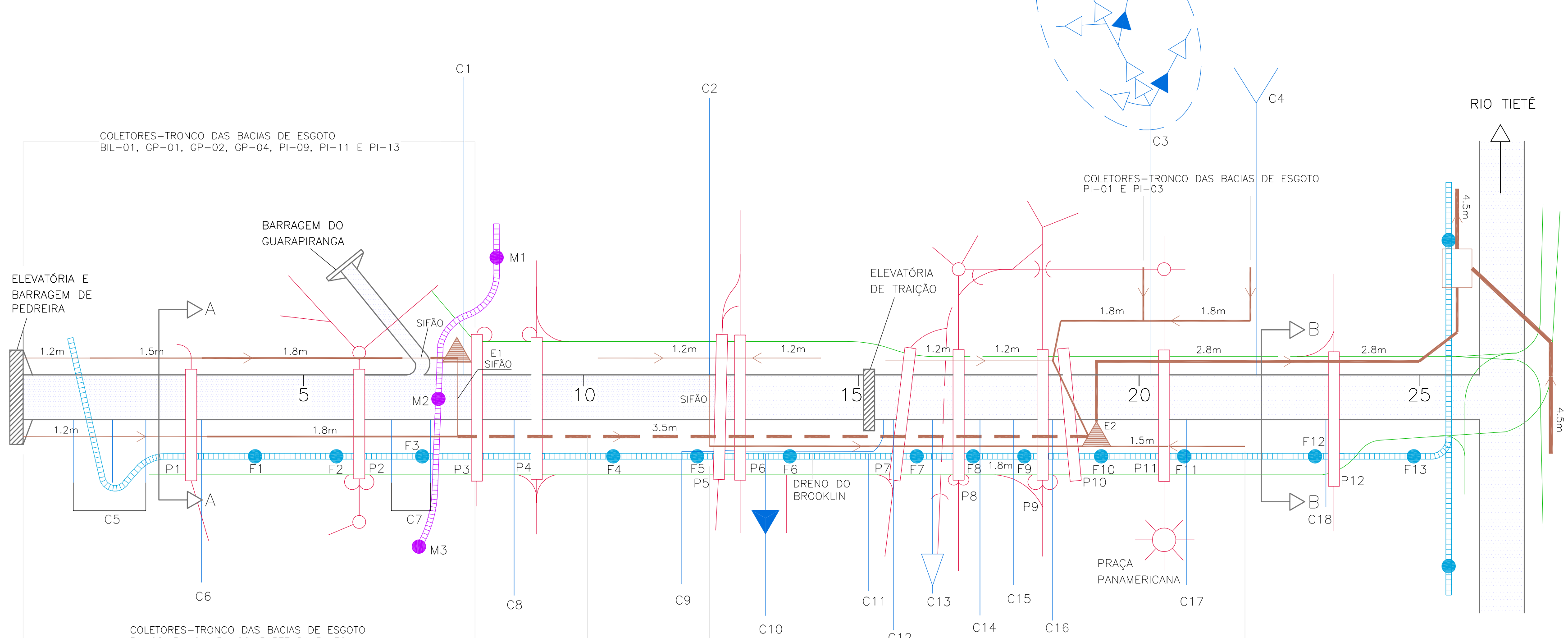

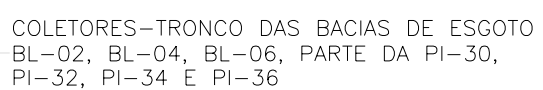

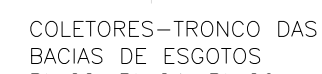

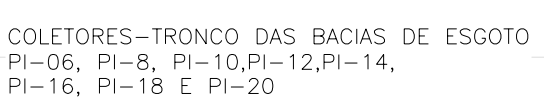

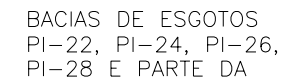

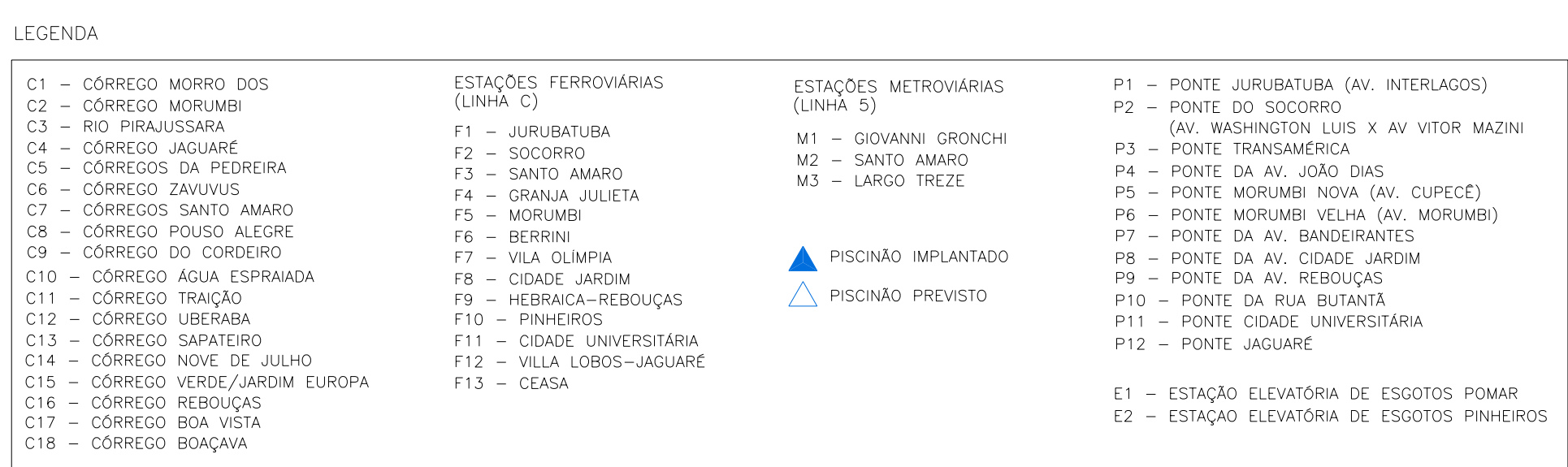


ampliação da análise da UTA, mais amplo que o anterior, pois o que se coloca, dessa vez, é o fluxo de energia elétrica em alta tensão, no âmbito de uma rede interligada de abrangência interestadual.

Todavia, o conceito de avaliação de uma proposição afirmativa (e não categórica), que deverá ser avaliada por um conjunto de especialistas, ao tornar necessárias diferentes avaliações individuais, será inevitavelmente condicionado tanto pelas experiências profissionais objetivas, como por inúmeros outros aspectos subjetivos de análise. Este fato, fundamental em todos os sentidos, torna indispensável o exercício da mais ampla liberdade de avaliação da proposição pelos diversos especialistas, que poderão condicionar e então relativizar suas avaliações, retirandolhes todo e qualquer caráter absoluto inclusive aqueles referentes à delimitação da UTA.

Trata-se, desta forma, de acrescentar à avaliação da proposição pelos especialistas, todos os argumentos, objetivos, situações, e conseqüências necessárias e/ou suficientes à análise, por ele identificáveis.

Cada um dos especialistas poderá então, a seu exclusivo critério, estabelecer faixas de valores que representem todo o espectro de argumentos, desde os totalmente favoráveis à proposição até aqueles totalmente desfavoráveis.

Considerando então, que para análise desta proposição, foram descritos ou relacionados 4 Grupos Afins, 12 Sistemas de Infra-estrutura Afetos e cerca de 57 Sub-sistemas Constituintes, conforme a Matriz dos Sistemas de Infra-estrutura Urbana geral aplicada especificamente a esta UTA (vide Quadro 2), uma relação de interdependência já se torna possível por uma simples integração de informações, que em tão diversos setores, já significará um ganho substancial no processo de análise e tomada de decisão. Todavia pretende-se construir, com a participação de especialistas, relações funcionais entre os grupos afins e os demais sistemas e subsistemas, nas quais os aspectos substantivos da viabilidade da proposição possam ser 
QUADRO 02

MATRIZ DOS SISTEMAS DE INFRA-ESTRUTURA URBANA APLICADA À UTA CANAL DO RIO PINHEIROS

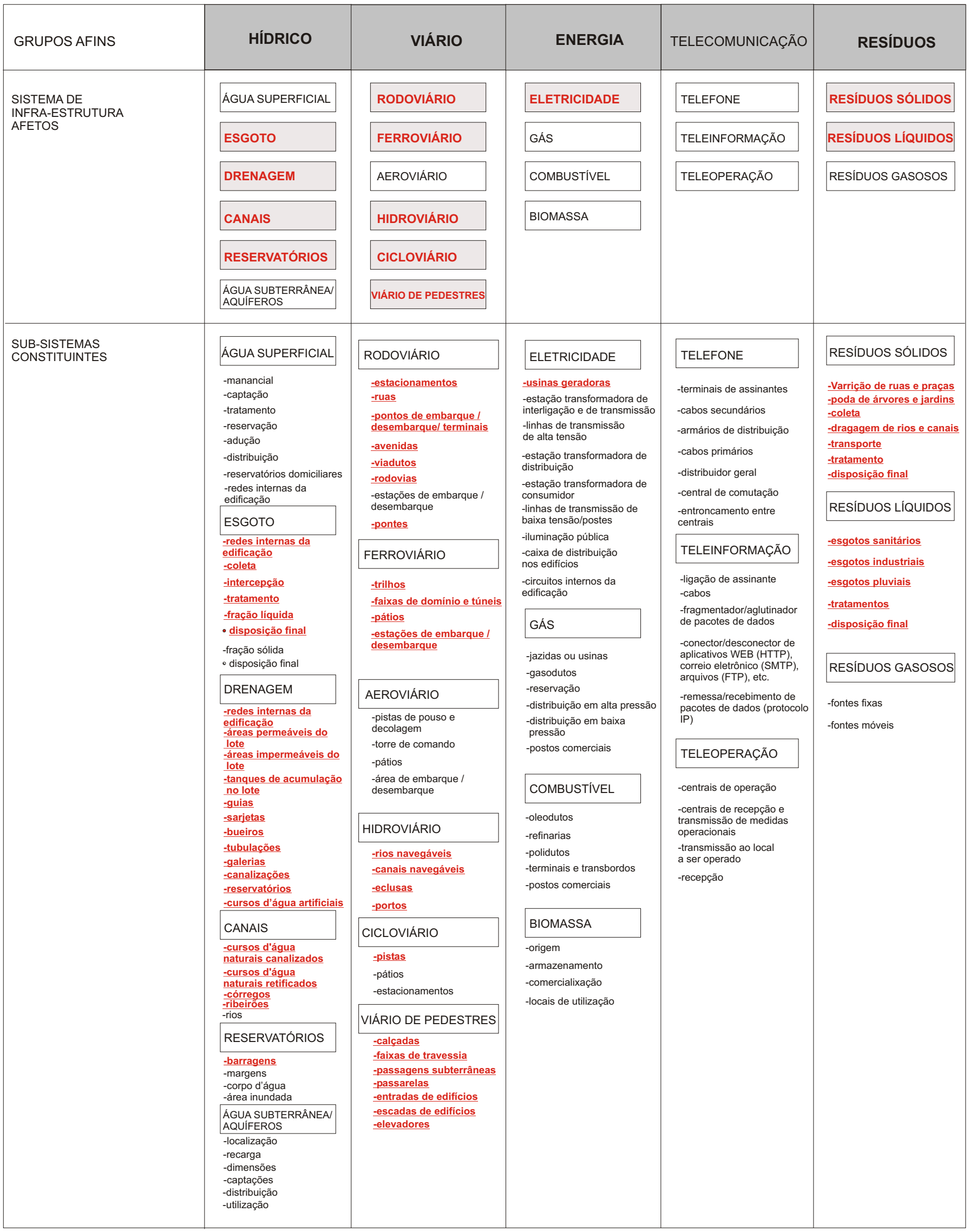

Grupos, sistemas e sub-sistemas existentes 
identificados e as entidades institucionais afetas se tornem co-participantes da sua viabilização.

Estas relações funcionais já se esboçam no elenco dos grupos, sistemas e subsistemas onde os especialistas serão mobilizados e ganham contornos mais nítidos com a participação efetiva de cada um deles, na perspectiva que se abre de construir uma nova rede social mais abrangente do que aquela em que cada entidade normalmente mantêm relações.

Para análise desta proposição, deverão ser mobilizados, no mínimo 4 especialistas, que corresponde ao número de Grupos Afins e, no máximo 57 que se refere ao número de Sub-sistemas, com o número 12 altamente significativo, relativo à quantidade de Sistemas.

Todavia, ao se levar em conta que a rede social começa a ser construída, num cenário de incomunicabilidade vigente, opta-se por um número restrito de 8 especialistas nos seguintes domínios considerados mais substantivos à análise da proposição: Subsistema Geração Hidroelétrica(1), Sistema Rodoviário Urbano(1), Sistema Ferroviário(2), Sistema de Esgotos(2), Sistema de Resíduos Sólidos(1) e Sistema de Drenagem(1).

Desta forma, deverá ser solicitado aos 8 especialistas, em relação à proposição “tornar o Canal do Rio Pinheiros navegável”, que definam para os diversos fatores de influência, em diversas opções e faixas, em todos os aspectos considerados afetos à sua especialidade, os seguintes parâmetros e argumentos:

- os graus de evidência favoráveis à proposição $\left(\boldsymbol{\mu}_{1}\right)$, no intervalo dos números reais zero (evidência favorável nula ou $0 \%$ ) e 1 (evidência favorável total ou $100 \%)$;

- os graus de evidência contrários à proposição( $\left.\boldsymbol{\mu}_{2}\right)$, no intervalo dos números reais zero (evidência contrária nula ou $0 \%$ ) e 1 (evidência contrária total ou $100 \%)$; 
- a explicitação de todos os argumentos necessários e/ou suficientes destas evidências, para o elenco de fatores de influência avaliados, detalhados cada qual nas suas respectivas opções e faixas de valores.

Os diversos fatores de influência, e cada um dos seus respectivos detalhamentos em opções e faixas, foram organizados segundo o Quadro da Base de Dados, com Valores dos Graus de Evidência Favorável $\left(\mu_{1}\right)$ e Contrária $\left(\mu_{2}\right)$ atribuídos pelos $\underline{8}$ Especialistas aos Fatores, Opções e Faixas, relacionados à Proposição "Tornar Navegável o Canal do Rio Pinheiros, situado a oeste do Município de São Paulo"( vide Quadro 3). Neste quadro, foram elencados 11 Fatores de Influência,subdivididos em 3 genéricos e 8 específicos, com um total de 32 opções / faixas

Considera-se que aos especialistas caberá necessariamente avaliar cada um dos fatores dentro do campo das suas especialidades e todos os fatores genéricos. Por outro lado, os especialistas não precisam se limitar exclusivamente ao campo de suas especialidades, podendo avaliar também todos os outros fatores opcionalmente.

Reconhece-se desta forma, que ao especialista será necessário avaliar os fatores genéricos e aqueles relacionados à sua especialidade. Ao mesmo tempo, considera-se uma prerrogativa absoluta do especialista avaliar qualquer um dos fatores de influência elencados, sobre os quais ele opte por se manifestar.

Os Fatores de Influência genéricos e suas Opções/Faixas são os seguintes:

- fator Potencial da Navegabilidade (G1) e 4 opções de navegação: estritamente turística, estritamente cargas. estritamente passageiros ou todas as alternativas;

- fator Prioridade para Sociedade (G2), com $\underline{3}$ opções: baixa, média ou alta;

- fator Viabilidade Econômico-financeira, com $\underline{3}$ opções: baixa, média ou alta.

Quanto aos Fatores de Influência específicos e suas Opções/Faixas, são propostos os seguintes: 
QUADRO 3 - BASE DE DADOS PARACONSISTENTE

VALORES DOS GRAUS DE EVIDÊNCIA FAVORÁVEL $\left(\mu_{1}\right)$ E CONTRÁRIA $\left(\mu_{2}\right)$ ATRIBUÍDOS PELOS 8 ESPECIALISTAS AOS FATORES E FAIXAS RELACIONADOS À PROPOSIÇÃO "TORNAR NAVEGÁVEL O CANAL DO RIO PINHEIROS, SITUADO A OESTE DO MUNICÍPIO DE SÃO PAULO

\begin{tabular}{|c|c|c|c|c|c|c|c|c|c|c|c|c|c|c|c|c|c|c|c|}
\hline & & & & & & & & & & & beci & stas & & & & & & & \\
\hline & & tores de Influência & Opções / Faixas & & & & & & & & & & & & & & & & \\
\hline & & & & $\mu_{1}$ & $\mu_{2}$ & $\mu_{1}$ & $\mu_{2}$ & $\mu_{1}$ & $\mu_{2}$ & $\mu_{1}$ & $\mu_{2}$ & $\mu_{1}$ & $\mu_{2}$ & $\mu_{1}$ & $\mu_{2}$ & $\mu_{1}$ & $\mu_{2}$ & $\mu_{1}$ & $\mu_{2}$ \\
\hline & & & Estritamente Turística & & & & & & & & & & & & & & & & \\
\hline & Gl & Potencial de & Estritamente Cargas & & & & & & & & & & & & & & & & \\
\hline & & Navegabilidade & Estritamente Passageiros & & & & & & & & & & & & & & & & \\
\hline & & Travegarmiducie & Todas as Alternativas & & & & & & & & & & & & & & & & \\
\hline o & & & Baixa & & & & & & & & & & & & & & & & \\
\hline$\frac{0}{2}$ & G2 & Prioridade para & Média & & & & & & & & & & & & & & & & \\
\hline$\stackrel{\bar{\Phi}}{\complement}$ & & Sociedade & Alta & & & & & & & & & & & & & & & & \\
\hline & & & Baixa & & & & & & & & & & & & & & & & \\
\hline & G3 & Viabilidade Econômico- & Média & & & & & & & & & & & & & & & & \\
\hline & & & Alta & & & & & & & & & & & & & & & & \\
\hline & & Geração de Energia Elétrica & Contínua & & & & & & & & & & & & & & & & \\
\hline & El & $\begin{array}{l}\text { com requisitos de vazóes no } \\
\text { Canal do Rio Pinheiros }\end{array}$ & Eventual & & & & & & & & & & & & & & & & \\
\hline & & & Nula & & & & & & & & & & & & & & & & \\
\hline & & & 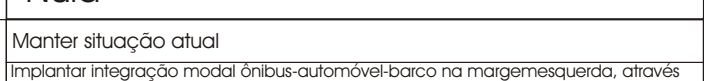 & & & & & & & & & & & & & & & & \\
\hline & E2 & Sistema Rodoviário & 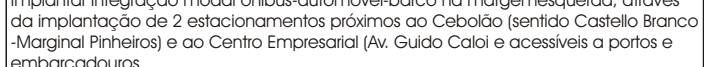 & & & & & & & & & & & & & & & & \\
\hline & & & 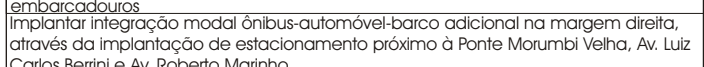 & & & & & & & & & & & & & & & & \\
\hline & E3 & Sistema Ferroviário & 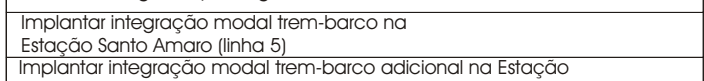 & & & & & & & & & & & & & & & & \\
\hline & ES & Trem Metropolitano & 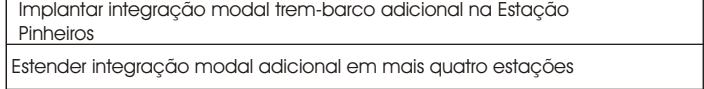 & & & & & & & & & & & & & & & & \\
\hline & & Sistema Ferroviário & $\begin{array}{l}\text { Manter tráfego de passagem na travessia } \\
\text { com o Canal do Rio Pinheiros }\end{array}$ & & & & & & & & & & & & & & & & \\
\hline$\frac{0}{0}$ & E4 & $\begin{array}{l}\text { Mietro (Projefo da Linna } \\
44 \text { Amarela) }\end{array}$ & $\begin{array}{l}\text { Implantar integração metrô-barco-trem } \\
\text { na Estação Pinheiros }\end{array}$ & & & & & & & & & & & & & & & & \\
\hline$\underset{\Omega}{1}$ & & & Até $7 \mathrm{~m}^{3} / \mathrm{s}$ & & & & & & & & & & & & & & & & \\
\hline 岀 & E5 & Sistema de Esgotos / & De $7 \mathrm{~m}^{3} / \mathrm{s}$ a $9 \mathrm{~m}^{3} / \mathrm{s}$ & & & & & & & & & & & & & & & & \\
\hline & & & Maior que $9 \mathrm{~m}^{3} / \mathrm{s}$ & & & & & & & & & & & & & & & & \\
\hline & & Sistema de Esgotos / & 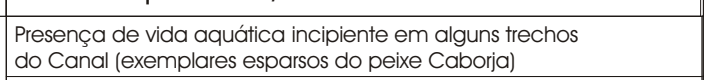 & & & & & & & & & & & & & & & & \\
\hline & E6 & Desempenho dos & $\begin{array}{l}\text { Presença de vida aquática diversifificada em alguns } \\
\text { trechos do Canal. }\end{array}$ & & & & & & & & & & & & & & & & \\
\hline & & Tratamentos nas ETEs & $\begin{array}{l}\text { Presençca de vida aquática diversificada em todos } \\
\text { os trechos do Canal. }\end{array}$ & & & & & & & & & & & & & & & & \\
\hline & & Sistema de Drenagem (manter níveis & Frequentemente & & & & & & & & & & & & & & & & \\
\hline & E7 & adequados à navegabilidade) & Permanentemente & & & & & & & & & & & & & & & & \\
\hline & & Sistema de Resíduos Sólidos / & Regurlamente & & & & & & & & & & & & & & & & \\
\hline & E8 & $\begin{array}{l}\text { Dragagem (manutençao do } \\
\text { Canal apto à Navegação) }\end{array}$ & Permanentemente & & & & & & & & & & & & & & & & \\
\hline
\end{tabular}


- fator de Geração de Energia Elétrica (E1), com $\underline{3}$ opções de requisitos de vazões no Canal do Rio Pinheiros, no sentido Billings: contínua, eventual ou nula;

- fator Sistema Rodoviário Urbano (E2), com $\underline{3}$ opções: manter situação atual, implantar integração modal ônibus-automóvel-barco na margem esquerda através da implantação de 2 estacionamentos próximos ao Cebolão (sentido Castello Branco-Marginal Pinheiros) e ao Centro Empresarial (Av. Guido Calói), e acessíveis a pontos e embarcadouros; implantar integração modal ônibusautomóvel-barco adicional, na margem direita, através da implantação de estacionamento próximo à Ponte Morumbi Velha, Av. Luiz Carlos Berrini e Av. Roberto Marinho;

- fator Sistema Ferroviário trem metropolitano (E3), com 4 opções: manter tráfego de passagem, implantar integração modal trem-barco na Estação Santo Amaro (Linha 5) ou implantar integração modal trem-barco adicional na Estação Pinheiros; estender integração modal adicional em mais quatro estações (seis no total);

- fator Sistema Ferroviário metrô (E4), com $2 \underline{2}$ opções: projeto da Linha 4 Amarela mantêm tráfego de passagem na travessia com o Canal do Rio Pinheiros ou propõe implantar integração metrô-barco na Estação Pinheiros;

- fator Sistema de Esgotos coleta e interceptação (E5) com $\underline{3}$ faixas da vazão de esgoto coletata: até $7 \mathrm{~m}^{3} / \mathrm{s}$, de $7 \mathrm{~m}^{3} / \mathrm{s}$ a $9 \mathrm{~m}^{3} / \mathrm{s}$ e maior que $9 \mathrm{~m}^{3} / \mathrm{s}$;

- fator Sistema de Esgotos tratamento (E6), com $\underline{3}$ opções em relação ao desempenho dos tratamentos nas ETEs: presença de vida aquática incipientes em alguns trechos do Canal (exemplares esparsos do peixe Caborja); presença de vida diversificada em alguns trechos do Canal; presença de vida diversificada em todos os trechos do Canal;

- fator Sistema de Drenagem (E7), com $\underline{2}$ opções de manutenção de níveis d'água no Canal do Rio Pinheiros adequados à navegabilidade: freqüentemente ou permanentemente;

- fator Sistema de Resíduos Sólidos dragagem (E8), com $\underline{2}$ opções de manutenção do Canal apto à navegação: regularmente ou permanentemente. 
Reitera-se que, a cada especialista, será dada plena e total liberdade para proceder às avaliações em parte ou em todos os 11 fatores e 32 opções/faixas de valores, independentemente das suas especialidades.

Após o preenchimento do Quadro Base de Dados, caberá ao autor da proposição - o propositor - a função de aplicar o Algoritmo Para-analisador aos dados coletados, para obtenção de relações funcionais entre os sistemas de infra-estrutura, sugerindo diferentes enfoques e ponderações às avaliações dos especialistas e dos nãoespecialistas Estas relações funcionais e ponderações deverão ser explicitadas ao tomador da decisão - o decisor - a quem caberá aceitá-las, ratificando as conclusões do propositor, ou não aceitá-las total ou parcialmente, solicitando-lhe eventualmente a alteração do teor da Proposição, um maior detalhamento em relação.a determinado Fator de Influência, a mobilização de um número maior de especialistas em determinados fatores, etc.

Ressalte-se desta forma, que o Quadro da BASE DE DADOS Valores dos Graus de Evidência Favorável $\left(\mu_{1}\right)$ e Contrária $\left(\mu_{2}\right)$ atribuídas pelos $\underline{8}$ Especialistas aos Fatores, Opções e Faixas relacionados à Proposição "Tornar Navegável o Canal do Rio Pinheiros, situado a oeste do Município de São Paulo", preenchido total ou parcialmente, constituir-se-á no dado de entrada para aplicar o Algoritmo Paraanalisador e calcular as relações funcionais resultantes das evidências favoráveis e contrárias, para o conjunto dos especialistas, em cada fator e opção, além do valor resultante final. Ressalta-se que os graus de contradição e certeza dessas resultantes também deverão ser calculados, segundo os critérios estabelecidos pela Lógica Paraconsistente Anotada.

São Paulo, março de 2004. 


\section{OS ESPECIALISTAS E SUAS AVALIAÇÕES: A BASE DE DADOS PARACONSISTENTE DA PROPOSIÇÂO}

Os Anexos 1 a 8 desta Tese explicitam, através de currículo sucinto e de conjunto de argumentos, o perfil biográfico de cada especialista e as razões que os levaram a avaliar as evidências favoráveis e contrárias à proposição, para o conjunto total ou parcial de 11 fatores e 32 opções ou faixas.

Quatro especialistas decidiram avaliar todos os fatores enquanto outros três limitaram-se exclusivamente aos fatores com avaliações obrigatórias, segundo os critérios necessário e opcional adotados na proposição; apenas o especialista $\mathbf{h}$ decidiu-se por não avaliar o fator de influência E5, enquanto o especialista $\mathbf{f}$ ao avaliar todos os fatores, resolveu não avaliar 4 opções/ faixas dos fatores G2 e G3.

Destaque-se, nos currículos dos especialistas, a abrangência das especialidades, que incluem o coordenador das atividades de operação, manutenção, limpeza e desobstrução de galerias, córregos e rios, em sub-prefeitura de São Paulo limítrofe ao Canal do Rio Pinheiros; o biólogo propositor de parâmetros biológicos de qualidade da água e especializado em corpos d'água da Bacia do Alto Tietê; os engenheiros responsáveis pela implantação e operação dos sistemas ferroviários e de esgotos; o geógrafo responsável por área ambiental da entidade operadora do Canal do Pinheiros; o engenheiro responsável pela operação das marginais e avenidas e o professor com larga experiência em obras hidráulicas e fluviais.

A Base de Dados Paraconsistente preenchida, com as diversas avaliações dos oito especialistas, está apresentada no Quadro 4. Esta Base de Dados demonstra a possibilidade de reunir especialistas na análise de uma proposição, permitindo unificar conhecimentos e experiências, homogeneizar os critérios de avaliação e, principalmente, resgatar toda a vivência desses profissionais que, cotidianamente e há anos, ocupam-se das atividades de operação, manutenção e ampliação dos sistemas a eles afetos. 


\section{QUADRO 4}

\section{BASE DE DADOS PARACONSISTENTE}

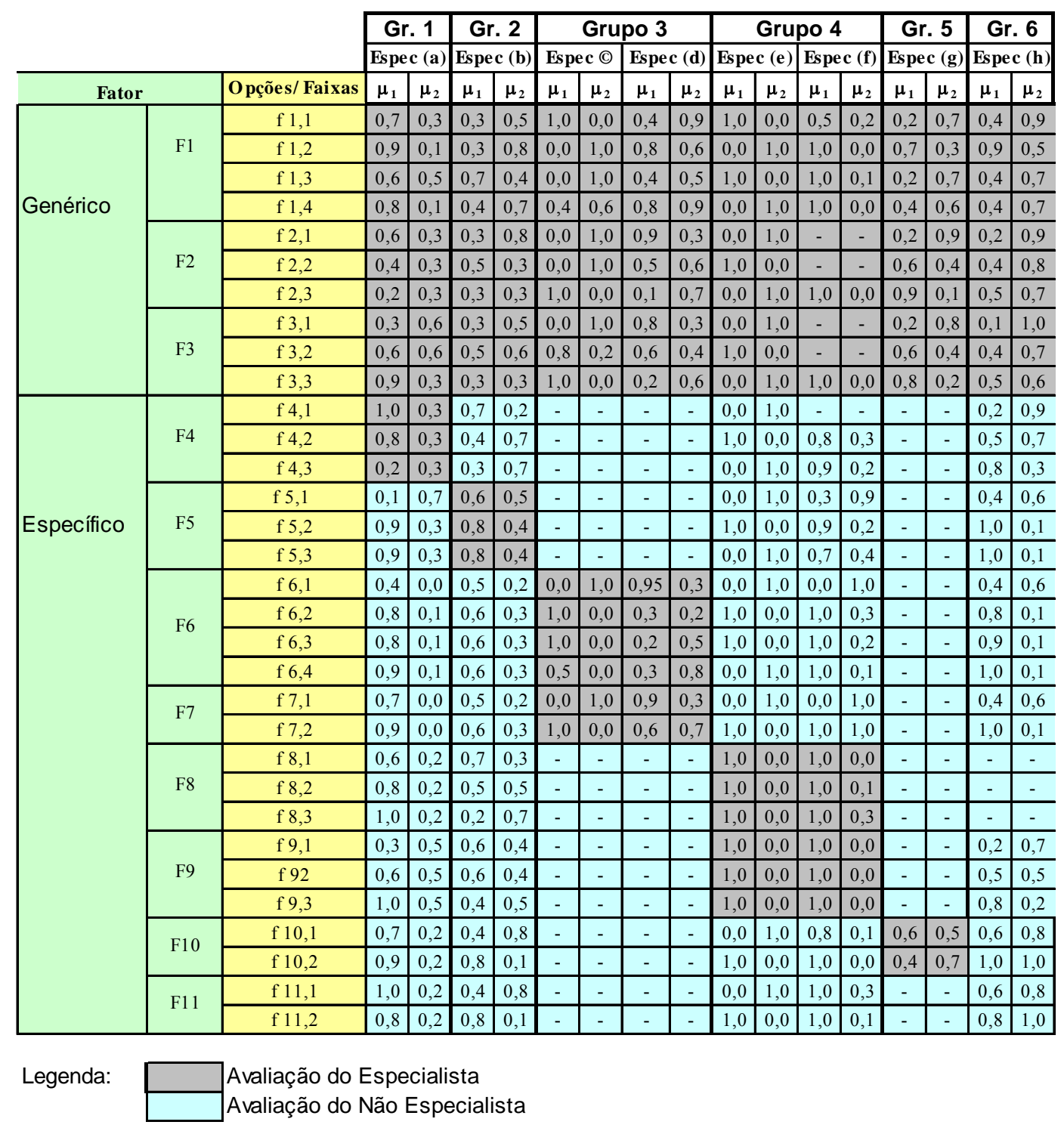




\section{O PROCESSAMENTO DA BASE DE DADOS PARACONSISTENTE}

Existem várias alternativas de processamento da Base de Dados Paraconsistente, que dependem basicamente de dois aspectos fundamentais:

- As relações estabelecidas entre o Propositor (ou equipe responsável pela Proposição), o Decisor (ou equipe de administradores responsáveis pela Decisão) e os Especialistas (ou grupos de especialistas dentro de suas especialidades), e

- As diretrizes estabelecidas nos estudos da Lógica Paraconsistente Anotada, que implicam na definição de valores relacionais e de intervalos desses valores.

No primeiro aspecto, preparou-se o Diagrama 1, denominado Fluxograma Geral das Relações entre Propositor, Especialistas e Decisor, para explicitar diversas possibilidades de relacionamento existentes entre eles. A partir da parte esquerda deste Fluxograma, o Propositor (ou equipe de propositores) define o teor da Proposição, com um conjunto de fatores de influência e as razões que a justificariam, submetendo-a a um elenco de Especialistas que a avaliam segundo os dois graus de evidência, favorável e contrário, preenchendo a Base de Dados Paraconsistente. Para um primeiro processamento desta Base de Dados, faz-se necessário definir, a priori, o número de especialistas, as relações entre os especialistas e os diferentes agrupamentos de suas especialidades; o conjunto dos diversos fatores de influência e de suas opções/faixas de variação e as diretrizes de processamento. Com os resultados deste primeiro processamento, o Decisor decide se concorda ou não com os fatores de influência e opções/faixas da proposição e com o número de especialidades e de especialistas ouvidos; em não concordando, recomenda ao Propositor alterações nestes pontos e o processo recomeça; em concordando, o Decisor decide-se quanto às diretrizes de processamento.

No segundo aspecto as diretrizes específicas do Estudo de Caso mesclam-se com diretrizes originárias da Teoria da Lógica Paraconsistente Anotada. 


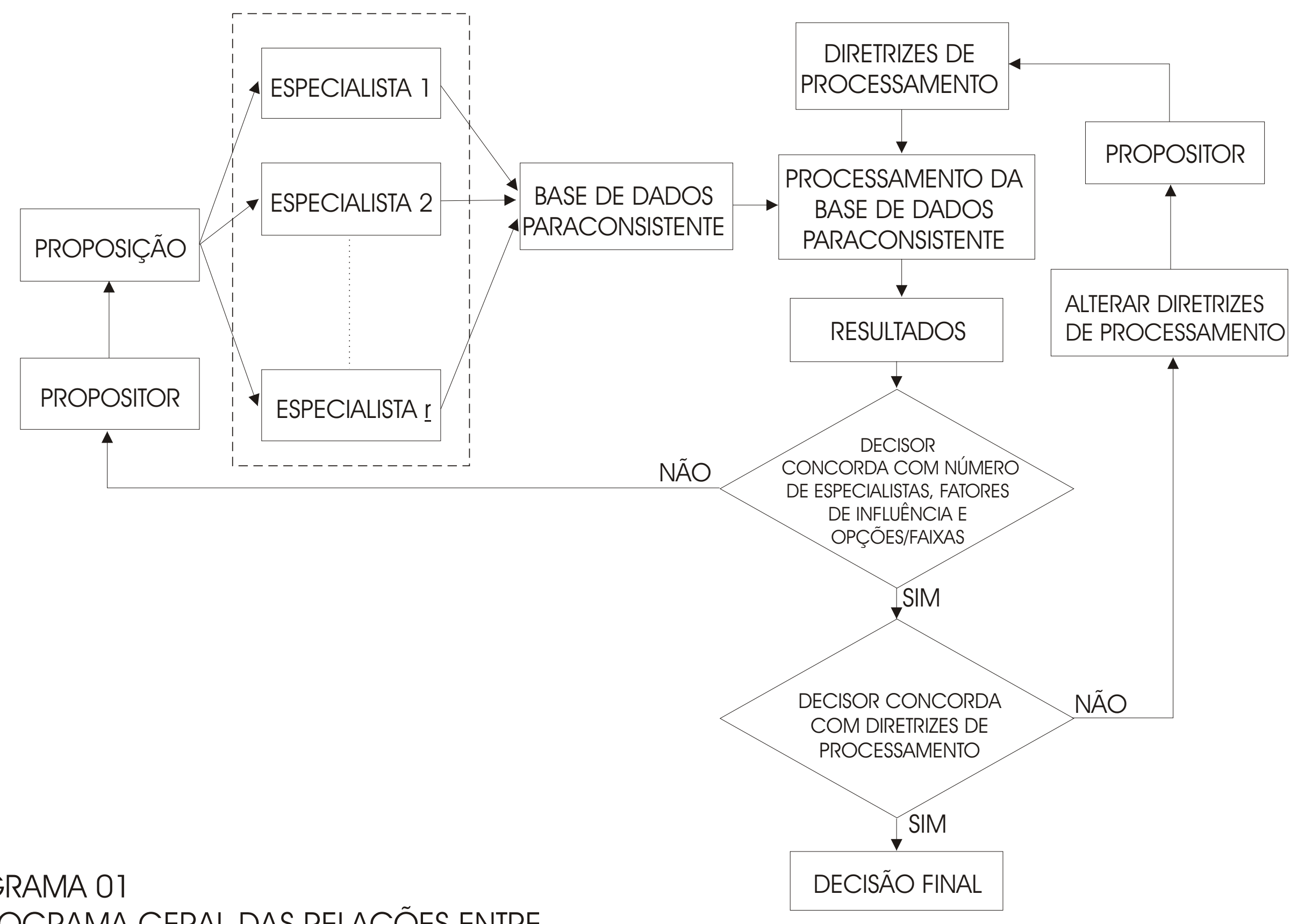

DIAGRAMA 01

FLUXOGRAMA GERAL DAS RELAÇÕES ENTRE 


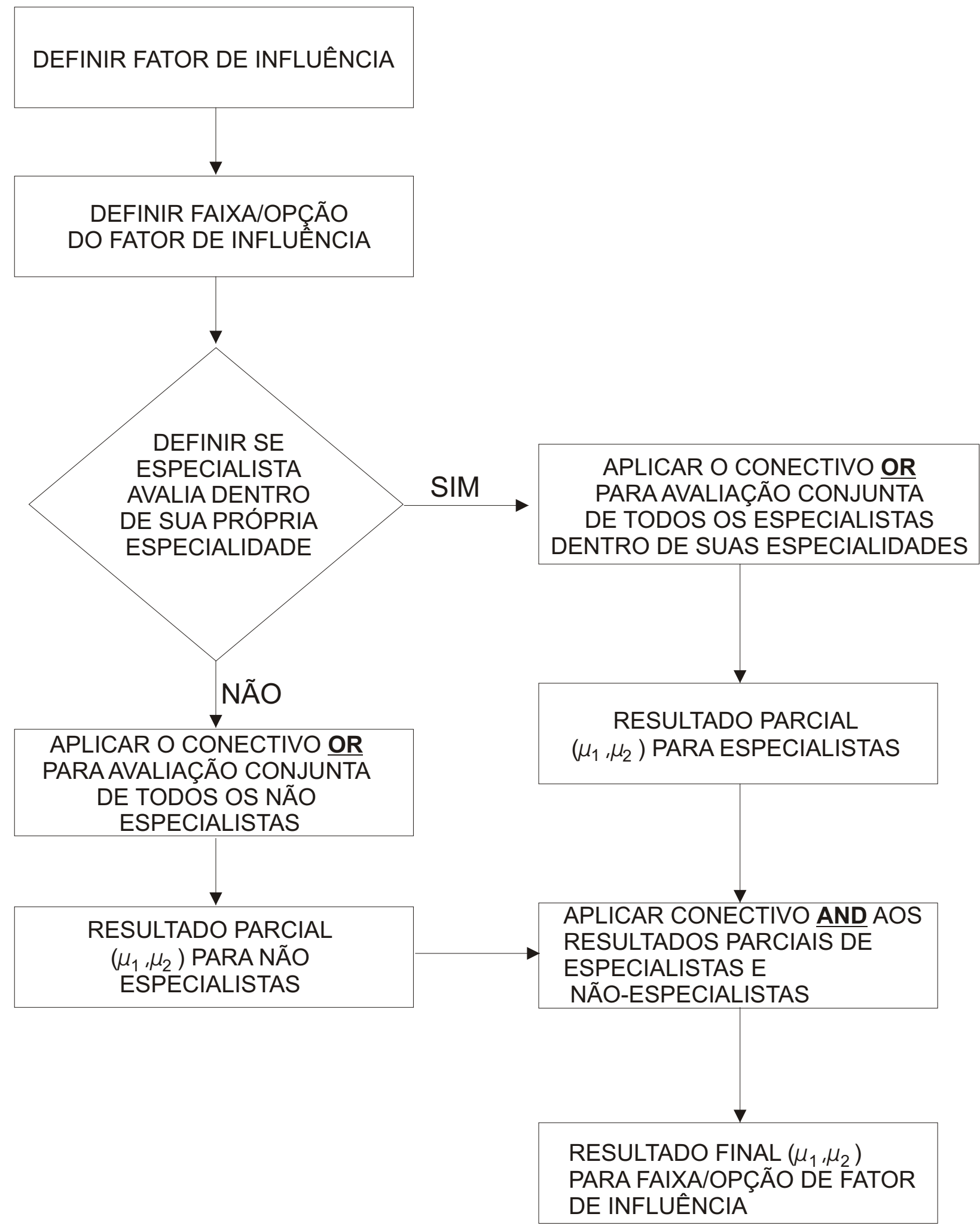

DIAGRAMA 02

CRITÉRIO DE PROCESSAMENTO PARA ESPECIALISTAS E NÃO-ESPECIALISTAS 
Uma primeira diretriz de processamento refere-se à organização dos especialistas. Os especialistas podem estar organizados em dois conjuntos de especialistas e nãoespecialistas ou em diversos grupos, dependendo da afinidade entre suas especialidades. O fluxograma Critérios de Processamento para Especialistas e Nãoespecialistas (Diagrama 2), define o primeiro procedimento, enquanto o fluxograma Critério de Processamento para Grupo de Especialistas (Diagrama 3), ilustra a segunda possibilidade de processamento: Dentro da primeira possibilidade (Diagrama 2), todos os especialistas opinariam em igualdade de condições face aos fatores genéricos e com prevalência de suas avaliações em fatores específicos relacionados às suas especialidades. Desta forma, para fatores genéricos seria aplicado o conectivo OR de maximização para as avaliações de todos os especialistas; para os fatores específicos, o conectivo OR seria aplicado inicialmente para as avaliações dos especialistas, depois para as dos não-especialistas e daí, o conectivo AND de minimização daria a resultante ou o resultado final das avaliações. Na segunda possibilidade (Diagrama 3), todos os especialistas de todos os grupos também opinariam em igualdade de condições face aos fatores genéricos, mas com eqüivalência de suas avaliações em fatores específicos relacionados aos seus diversos grupos. Desta forma, para fatores genéricos seria aplicado o conectivo OR de maximização para as avaliações de todos os especialistas em todos os seus grupos; para os fatores específicos, o conectivo OR seria aplicado inicialmente para as avaliações dos diversos grupos de especialistas, e daí, o conectivo AND de minimização daria a resultante final das avaliações. Para uma interpretação gráfica dos conectivos OR e AND da Lógica Paraconsistente anotada, preparou-se o Diagrama 4, que permite visualizar a união e a interseção de conjuntos e sua representação no QUPC.

Qualquer uma dessas alternativas, ou eventualmente outras possíveis, podem ser utilizadas. Na situação específica deste Estudo de Caso, adotou-se a diretriz de processamento da Base de Dados Paraconsistente segundo o critério de especialistas ou não-especialistas (Diagrama 2), relativamente ao campo de fatores de influência de suas especialidades, resultando duas situações expressas graficamente na Base de 


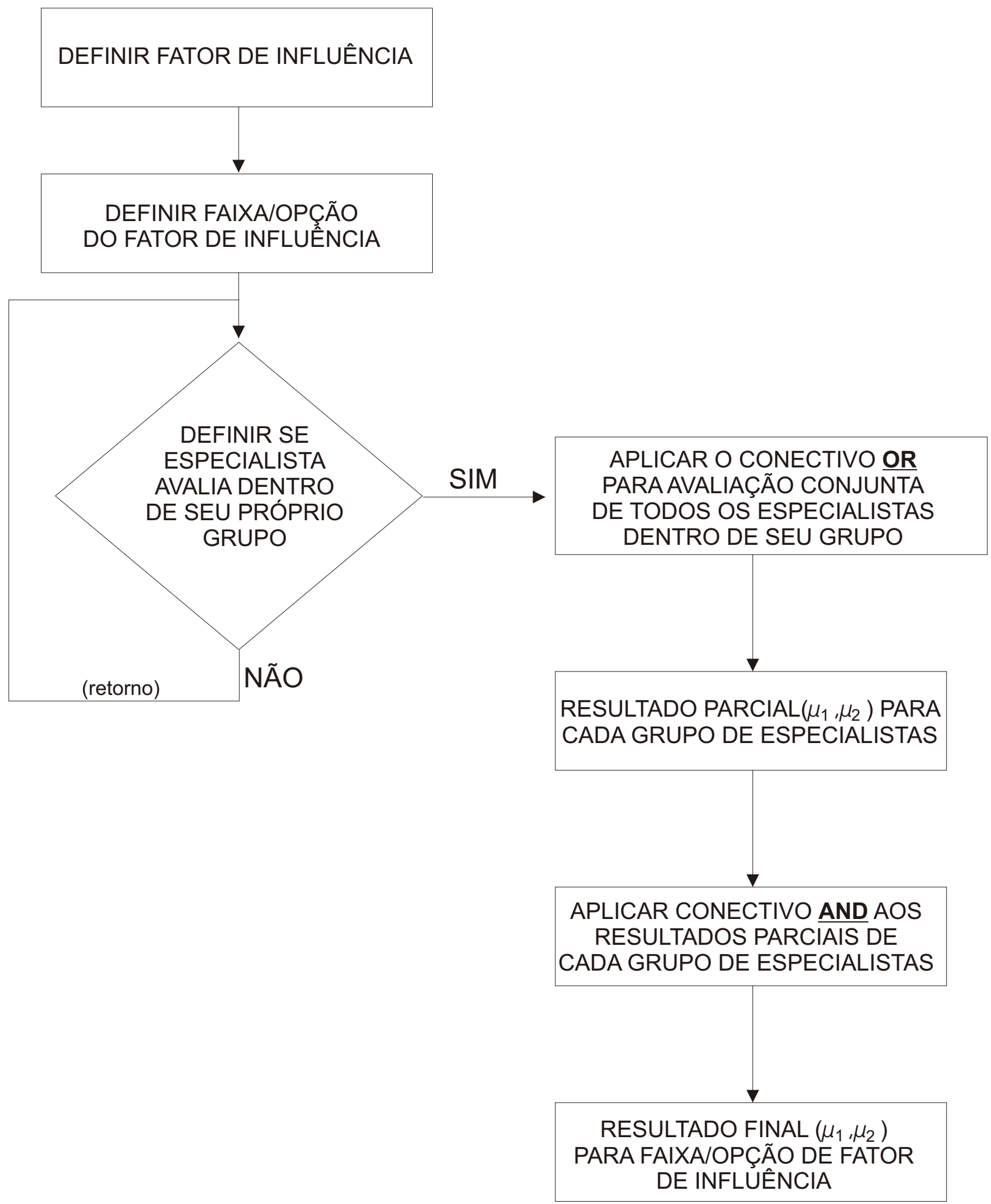

DIAGRAMA 03

CRITÉRIO DE PROCESSAMENTO PARA GRUPO DE ESPECIALISTAS 
Conectivo OR : maximização ou união das avaliações

Conectivo AND: minimização ou intersecção das avaliações
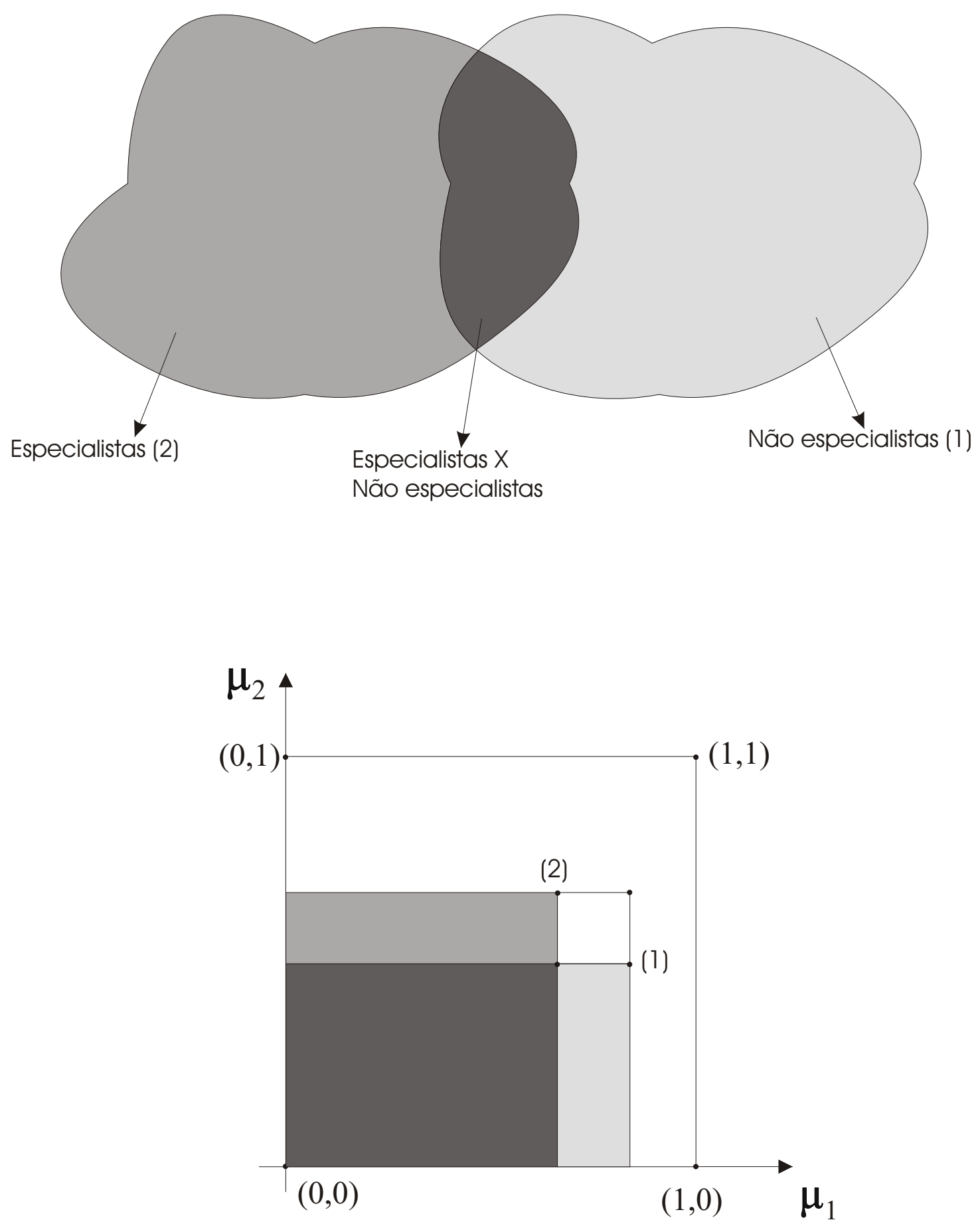
Dados: o campo hachurado da avaliação dos especialistas e o campo não hachurado da avaliação dos não-especialistas.

Uma segunda diretriz de processamento refere-se às diversas ponderações entre os fatores e as opções/ faixas de cada um dos fatores. Constata-se sua importância nos resultados de avaliação da proposição, o que retira tal responsabilidade do âmbito exclusivo das atribuições do Propositor, inscrevendo tal decisão - os pesos - na alçada de atribuições do decisor, a quem o propositor normalmente se reporta. De fato, a relevância da atribuição dos pesos, para cada fator em relação aos demais e para cada faixa/opção em relação às demais, pode apoiar-se numa escala dos benefícios tangíveis da proposição, e/ou reconhecer sua importância em função de prioridades sociais e/ou considerar a maior ou menor aderência da decisão em relação aos compromissos corporativos ou institucionais do Decisor. De qualquer maneira, é considerado fundamental que possam ser realizados testes de sensibilidade das diversas ponderações e que, através de processamentos sucessivos, torne-se possível estabelecer a convergência para uma situação de equilíbrio relativo entre os pesos. No contexto específico do Estudo de Caso, foram adotados pesos para os fatores de influência e para as opções / faixas, que consideram os fatores genéricos como um quarto e os específicos como três quartos das ponderações. Dentre os fatores genéricos, a viabilidade econômico-financeira tem a menor importância relativa, já que os investimentos mais pesados de acessibilidade às margens do canal e de despoluição dos seus corpos d'água, estão sendo realizados, segundo as prioridades dos diversos órgãos afetos. Em relação aos fatores específicos, valorizouse mais os fatores com conotações ambientais e os de integração trem-barco, pelo fato dos trilhos e estações da Linha $\mathrm{C}$ estarem implantados na margem direita, entre o Canal e a Marginal com grande acessibilidade já existente.

Uma terceira e última diretriz diz respeito à escolha de um ou mais valores relacionais propostos pela Lógica Paraconsistente Anotada, ou seja os graus de inconsistência, de indeterminação, de verdade, de falsidade, de contradição e de certeza, definidos na teoria da Lógica Paraconsistente Anotada, com a fixação dos 
valores de controle superior e inferior. Para este Estudo de Caso, optou-se pela adoção do valor relacional Grau de certeza, já definido no item 4.5.3.1.

Desta forma, o processamento da Base de Dados é realizado montando-a sobre uma planilha Excell, considerando a aplicação do conectivo OR (ou maximização) para as avaliações dos especialistas e dos não-especialistas e, do conectivo AND (ou minimização), para associar as avaliações resultantes dos especialistas e dos nãoespecialistas. Conseguida uma avaliação resultante para cada uma das opções/ faixas de um determinado fator de influência, multiplica-se este resultado à sua respectiva ponderação para obter o resultado final.

No Estudo do Caso, a decisão final é viável, com critério do grau de certeza de 0,3 ou 30\%. Para cada opção/faixa e para cada fator, também existem decisões explicitadas segundo graus de certeza menores, arbitrados em maiores que 0,1 (em $10 \%)$ para decisões viáveis, menores que $-0,1(-10 \%)$ para inviáveis e entre os dois valores para não conclusivos.

Os resultados finais estão apresentados no Quadro 5 Base de Dados Paraconsistente -Processamento e possibilitam diversas leituras por parte do Decisor. Uma das leituras possíveis é a seguinte: a potencialidade da navegação turística é baixa enquanto sua viabilidade econômico-financeira é média; além disso, os requisitos de vazão no sentido Billings revelam-se viáveis de forma contínua ou eventual com maior certeza na eventualidade (50\%); no tocante à integração modal carro-barco com grau de certeza 50\% esta revela-se viável na Margem Esquerda e com certeza de 40\% na Margem Direita; o aspecto integração modal trem-barco, revela-se altamente viável na Estação Santo Amaro (certeza de 80\%) e na Estação Pinheiros (certeza de 70\%); no tocante à integração modal metrô-barco, a viabilidade é média da ordem de apenas 30\%; em relação à retirada dos esgotos, em todas as faixas de valores, a certeza é uniforme no patamar 70\%; em relação à viabilidade de vida aquática diversificada, resulta uma certeza total na consecução deste resultado; em relação à manutenção de níveis d'água no canal adequados à navegação, a certeza é baixa, 
QUADRO 5 - BASE DE DADOS PARACONSISTENTE PROCESSAMENTO

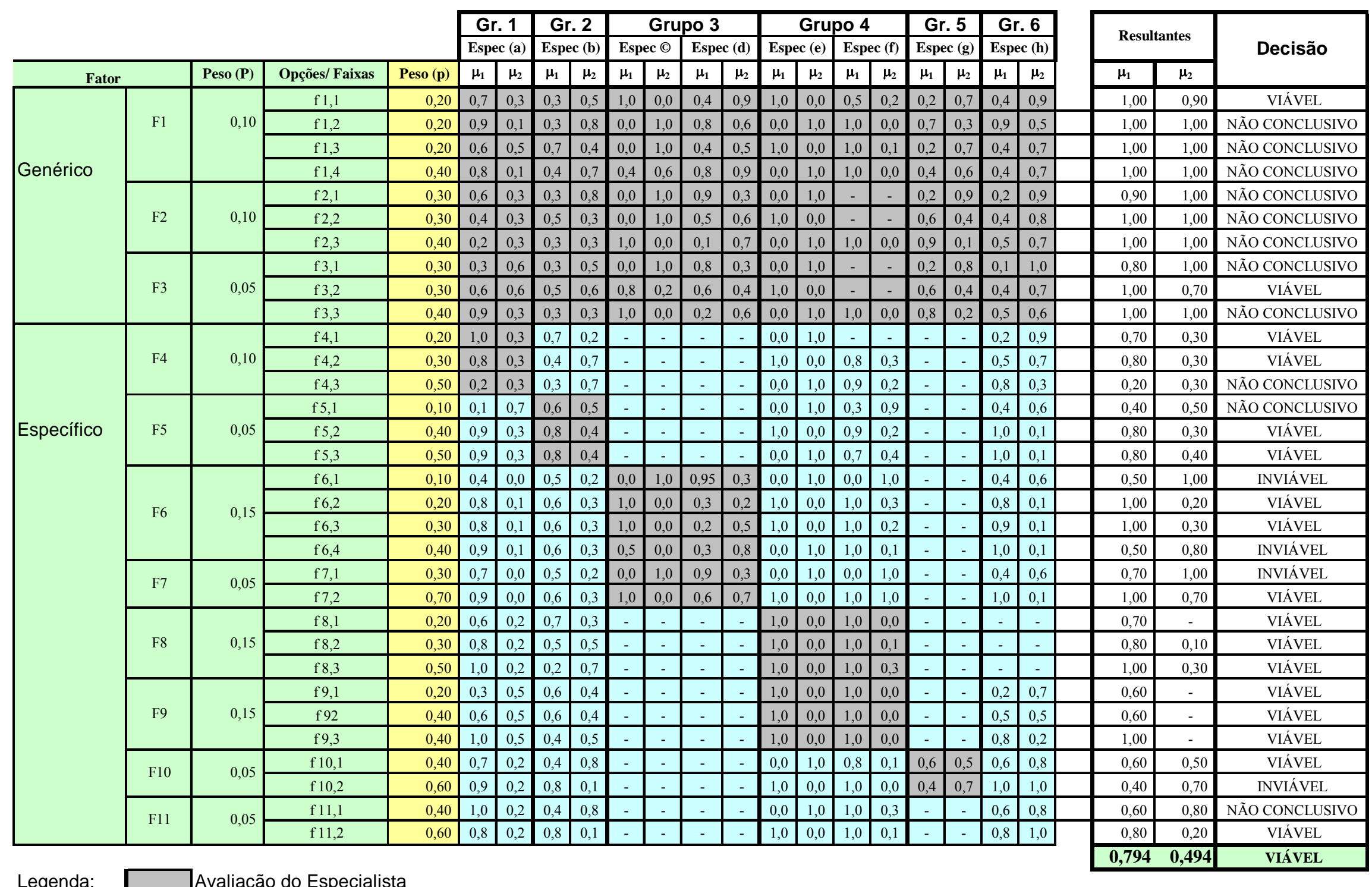

Legenda: Avaliação do Não Especialista 
requerendo provavelmente maiores discussões e novos especialistas; finalmente no aspecto viabilidade de manter a seção do canal apta à navegação a certeza é de $60 \%$.

Os resultados finais apresentados no Quadro 5 representam relações estabelecidas entre Decisor, Propositor e Especialistas, são ilustrativos de uma única situação: 11 fatores de influência, 32 opções/ faixas, 8 especialistas, graus de certeza superior de $10 \%$ e inferior de $-10 \%$ e ponderações especificadas. O que deve ser ressaltado, como uma das principais qualidades deste Método, é a possibilidade de alterar valores das ponderações, retirar ou acrescentar especialistas, alterar valores superior e inferior dos graus de certeza, acrescentar outros valores relacionais como graus de contradição ou de verdade, etc criando as condições necessárias para sucessivos testes de sensibilidade das resultantes finais de avaliação da Proposição. 


\section{CONCLUSÕES}

As possibilidades que se abrem à aplicação do Método das Bases de Dados Paraconsistente, para avaliar preposições relativas à gestão integrada de sistemas de infra-estrutura urbana, são amplas.

Como exemplos possíveis desta potencialidade, pode-se elencar as seguintes proposições:

- proposição "viabilizar o tele-trabalho em uma cidade": neste caso os grupos afins viários e telecomunicações da Matriz de Sistemas de Infra-estrutura predominam na definição dos fatores e das opções/faixas;

- proposição "garantir acessibilidade permanente às regiões centrais de metrópoles": neste caso, os grupos afins hídrico, viário, telecomunicação e resíduos, deverão ser analisados para serem definidos os fatores e as opções/faixas;

- proposição "reduzir o impacto ambiental de um empreendimento": neste caso, os grupos afins deveriam ser identificados e daí seriam definidos os fatores e as opções/faixas da Base de Dados Paraconsistente.

Em todos estes exemplos, necessita-se formular a Proposição, com sua defesa através de argumentos de caráter histórico, de síntese da situação atual e da construção de um cenário estratégico e de curto prazo. Isto deverá ser feito pelo Propositor, em estrita cooperação com os diversos gestores dos diversos órgãos competentes, resultando na explicitação final dos fatores de influência e das opções/ faixas da Base de Dados Paraconsistente. Esta deverá estar concluída apenas com a definição do conjunto dos especialistas, de suas especialidades e de seus grupos.

Como critérios gerais para montagem de base de dados paraconsistente, foram preparados o Diagrama 5, denominado Base de Dados Paraconsistente- Critérios Gerais de Montagem/ Fluxograma e o Diagrama 6 sob o título Base de Dados Paraconsistente Critérios Gerais de Montagem/Matriz, que estão anexos e que ilustram os procedimentos gerais para integrar $\underline{\mathbf{n}}$ fatores de influência, $\underline{\mathbf{m}}$ 
faixas/opções de cada fator, as ponderações dos fatores $(\mathbf{P})$ e das faixas/opções $(\mathbf{p}), 0$ conjunto de especialistas (r) e eventualmente até ponderações para os especialistas e /ou especialidades.

Quanto ao processamento, existe vasta literatura para montagem de rotinas de cálculo para casos específicos, como realizado neste Estudo de Caso descrito. Para a generalização deste Método da Base de Dados Paraconsistente contudo, torna-se necessário desenvolver e/ou utilizar rotinas de cálculo genéricas. Ressalte-se que encontra-se disponibilizado Algoritmo Paranalisador, em forma patenteada, conforme referência (Costa, Silva Filho e Abe, 2002).

É necessário afirmar, finalmente que a Lógica Paraconsistente Anotada tem um enorme potencial de utilização, que está apenas se iniciando e no qual o Método da Base de Dados Paraconsistente, para Integração de Sistemas de Infra-estrutura, é apenas uma das utilizações possíveis. Mesmo em se considerando apenas o caso deste Método para esta aplicação, faz-se necessário promover elaborações adicionais, visando aprimorá-lo, preparando-o para incorporar os desenvolvimentos mais recentes das pesquisas neste domínio das Lógicas Não Clássicas. 

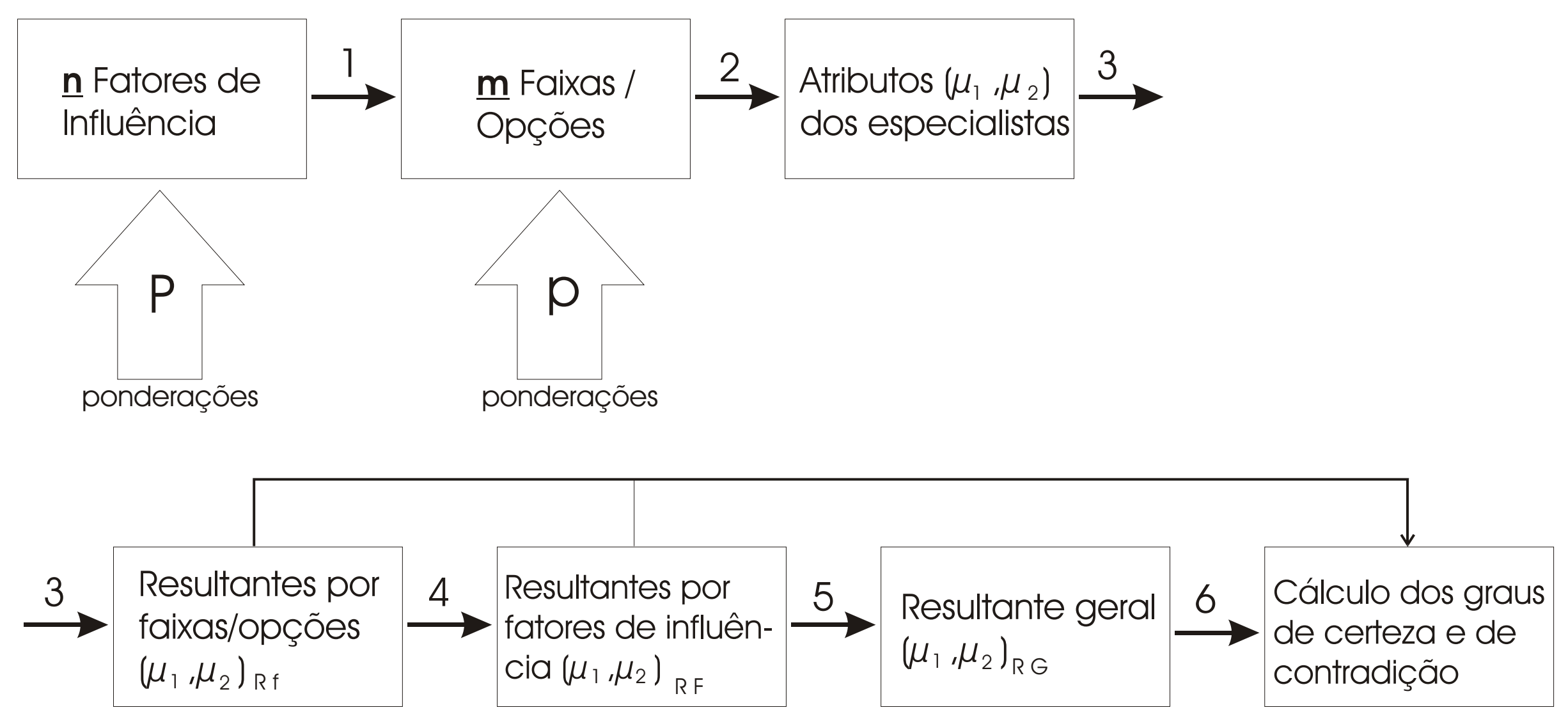

$\begin{aligned} \text { Proposição Genérica com: } & \frac{\mathbf{n}}{\mathbf{m}} \text { fatores de influência (F) } \\ & \underline{\mathbf{P}} \text { ponderaçõões dos fatores } \\ & \underline{\mathbf{p}} \text { ponderações das faixas/ opções } \\ & \underline{\mathbf{r}} \text { especialistas } \\ & \underline{\mathbf{G}} \text { ponderações dos especialistas }\end{aligned}$

DIAGRAMA 05

- Base de Dados Paraconsistente

- Critérios Gerais de Montagem/Fluxograma 


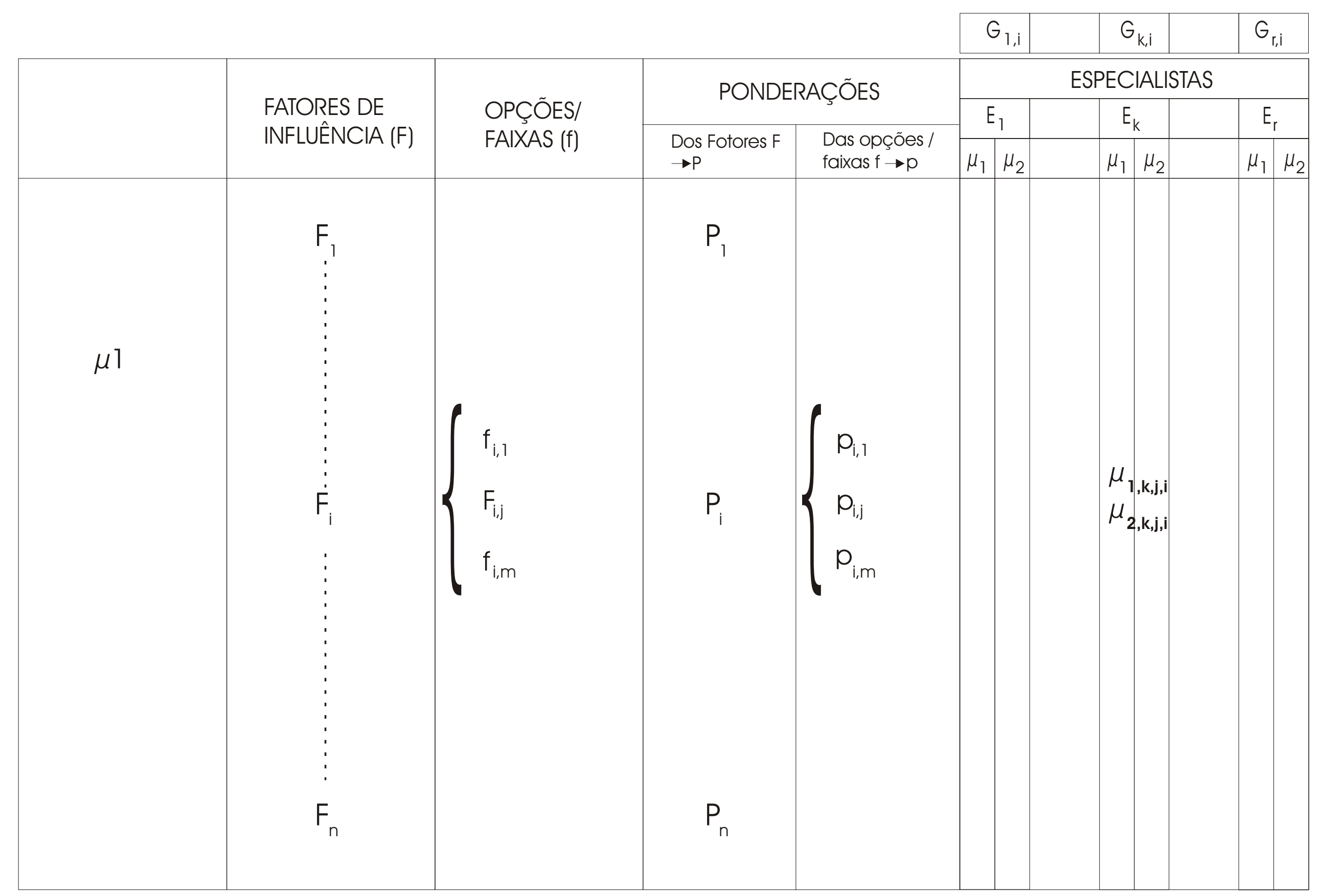


Anexo I: Avaliação do Especialista a

Prof. Podalyro Amaral de Souza 
Prof ${ }^{\circ}$. PODALYRO AMARAL DE SOUZA - Entrevista Final em abril de 2004

\section{Currículo sucinto}

Nascido em Óbidos, ali cursou o primário e o ginasial, e o colegial em Santarém; graduou-se em Engenharia Civil na EPUSP em 1971. Desde 1975, leciona Hidráulica Geral na EPUSP. Em 1978 obteve o título de Mestre em Engenharia Hidráulica. Em 1979/80 realizou estágio no HRS (Hydraulic Research Intitute) em Wallingford, Inglaterra, onde especializou-se em modelação matemática. Em 1985 , obteve o título de Doutor pela EPUSP. Foi diretor geral do CTH - Centro Tecnológico de Hidráulica de 1995 a 1997. Atua principalmente em pesquisas relativas a estruturas hidráulicas. Dentre suas inúmeras atividades acadêmicas, merece destaque a orientação a 33 pós-graduandos sendo 20 mestres e 13 doutores.

\section{$\underline{\text { Argumentos da Avaliação (Especialista a) }}$}

- Porque prioridade para carga ? Ela não reclama de cheiro, logo tem menos óbices;

- Turismo é eventual e passageiro é freqüente;

- Prioridade: valorização que a sociedade dá à existência de navegação é pequena;

- Considera altamente viável navegar no canal;

- Considera navegação convergente com a geração hidroelétrica em Henry Borden / Cubatão;

- Marginais: situação atual é desarticulada e insuficiente; devem ser adicionadas opções de integração , estacionamentos devem ser implantados;

- Metrô: integrar deve ser a política e quanto mais, melhor

- Esgotos: evidência favorável maior, quanto maior for a coleta e interceptação;

- Tratamento de esgotos: é viável vida diversificada nas águas do canal;

- Drenagem e níveis d'água permanentes adequados à navegabilidade: canal tem estruturas hidráulicas suficientes para operação com critérios de permanência dos níveis; 
- Dragagem e manutenção de seções do canal: não há necessidade de dragagem permanente, mas deve ser regular; é possível programar dragagem por entropia máxima, o que reforça a opção por "regularmente". 
Anexo II: Avaliação do Especialista $\underline{\mathbf{b}}$

Eng. ${ }^{\circ}$ Hemilton T. Inoye 
Eng $^{\circ}$ HEMILTON INOUYE - Entrevista Final em abril de 2004

\section{$\underline{\text { Currículo sucinto }}$}

Nascido em Cruzália em 1965, mudou-se para cursar faculdade de São Paulo em 1984. Graduou-se em Tecnologia da Construção Civil - opção Obras Hidráulicas pela FATEC-SP em 1988 e em Engenharia Civil pela Universidade de Guarulhos em 1993. Durante o curso de Tecnologia, em janeiro de 1986, ingressou na CET como estagiário e em julho foi efetivado como técnico de transportes. Trabalhou inicialmente no Departamento de Engenharia de Campo da Região de Santana (abrange bairros da Zona Norte do Município de São Paulo); atuando sobre o viário urbano, neste mesmo departamento, trabalhou em diversas áreas da Cidade de São Paulo, com responsabilidades e funções crescentes (Freguesia do Ó, Lapa, Pinheiros, Casa Verde, Moóca, Sé, Vila Mariana, etc). Desde 2002, é coordenador de engenharia de tráfego da CET, responsável pela Marginal Pinheiros e Av. dos Bandeirantes.

\section{$\underline{\text { Argumentos de Avaliação (Especialista b) }}$}

- Os usuários de automóvel do sistema Marginais Pinheiros / Av. dos Bandeirantes tem renda de média para alta e poderiam interessar-se por modal hidroviário associado ao carro, desde que a viagem seja confortável e prazerosa, competindo com o tráfego pesado da Marginal;

- Uma parcela grande desses usuários de automóvel inicia sua viagem fora do município de São Paulo (Alphaville, Vinhedo, Jundiaí, etc) e dirigem-se à Marginal do Rio Pinheiros no trecho sul, após a Bandeirantes (onde há predomínio dos carros) e tem obrigatoriamente de cruzar o trecho do Cebolão - Av. dos Bandeirantes, conflitando com o tráfego pesado de caminhões que tem como destino a Av. dos Bandeirantes e o Porto de Santos;

- Os usuários de ônibus fretados, normalmente originários de cidades mais longínquas (cerca de $80 \mathrm{~km}$ da Cidade de São Paulo no quadrante Sorocaba Campinas), não seriam sensíveis ao apelo da navegabilidade; 
- Cargas: existem dificuldades de transbordo;

- Turismo: considera de grande relevância para a cidade;

- Viabilidade: considera baixa;

- Metrô/ Trem: renda inviabiliza usuário para conexão com barco;

- Integração modal ferrovia/barco: favorável à preparação de diversas situações de integração para o futuro;

- Esgoto: não acredita na vida aquática;

- Drenagem: deve ser permanente; existem problemas de microdrenagem em cerca de 6 locais (Rua Alvarenga, Av. Eng ${ }^{0}$ Billings, próximo ao Cebolão, depois da curva da Traição, próximo à ponte Ary Torres e $100 \mathrm{~m}$ da ponte Ary Torres);

- Lixo / Dragagem: deve ser permanente; a cada duas semanas, é feita a varrição, poda e capinagem das marginais, (programadas para sábados de manhã, por problemas de custo), com cerca de 60 homens, 6 máquinas e 3 frentes de limpeza.

Observa que o desempenho da administração pública influencia decisivamente sua posição: descontinuidade administrativa e pouca eficiência dos programas públicos. 
Anexo III: Avaliação do Especialista c Arq. Renato Pires de Carvalho Viégas 
Arq. RENATO VIÉGAS - Entrevista final em abril 2004

\section{$\underline{\text { Currículo sucinto }}$}

Nasceu em São Paulo em 1943, teve seu primário, ginasial, colegial e arquitetura na Universidade Mackenzie, onde graduou-se em 1967. Lecionou no IAD - Instituto de Arte e Decorações no período de 1969 a 1971 e na FAAP no Curso de Comunicações de 1969 a 1972.

Teve escritório privado de arquitetura e foi arquiteto do Hospital das Clínicas até 1972.

Neste ano, ingressou no Metrô como arquiteto; foi coordenador de projeto, gerente de operações (período 1983-88) no CCO Paraíso, gerente de projetos (89/90), assessor da presidência do Metrô e do CONFEA; trabalhou no CNPq no período de 91 a 93 e foi responsável pela Gerência de Projetos da CPTM em 1993/94.

De 1994 a 1995, na EMPLASA, respondeu pela assessoria da Diretoria de Planos e Projetos.

Voltou ao Metrô como Chefe do Departamento de Tecnologia e Concepção de Projetos (1996/1999), quando aposentou-se.

Assumiu a Gerência de Planejamento da CPTM em 1999 onde permaneceu até 2003. Desde 2003 é diretor de Planejamento e Expansão dos Transportes Metropolitanos do Metrô, assumindo estas responsabilidades também sobre os sistemas de trens e ônibus metropolitanos.

\section{$\underline{\text { Argumentos de Avaliação (Especialista c) }}$}

- Premissas básicas: 1) O eventual serviço de transporte hidroviário no Canal do Pinheiros reveste-se de características predominantemente turísticas, já que corre paralelo a um transporte de massa (Linha C da CPTM), integrando o Sistema Estadual Metropolitano sobre trilhos. 2) o sistema hidroviário poderá atuar complementarmente, integrado ao sistema sobre trilhos, com duas vertentes possíveis : a primeira longitudinal, ao longo do canal, estabelecendo ligações hidroviárias regulares expressas entre região do 
Jaguaré e região da Berrini e a segunda transversal, estabelecendo conexão (de travessia) entre as margens direita e esquerda do canal, preferencialmente localizadas nas regiões de Pinheiros - Butantã e Santo Amaro - Socorro;

Desta forma, as principais condicionantes das evidências favoráveis e contrárias são:

- Possibilidade de ampliação da acessibilidade a sítios e locais turísticos, explorando as potencialidades dos lagos dos Billings e Guarapiranga, implantando obras e equipamentos de transposição de nível nas barragens e Elevatória de Traição;

- Viabilidade econômico-financeira: grande potencial de negócios baseados no turismo;

- Sistema de saneamento precisa ter maior visibilidade social mediante incorporação de outros objetivos, além dos estritamente relacionados aos serviços da SABESP; considerar que o resgate dos rios terá uma influência fundamental no redesenho da cidade, no hábito dos seus habitantes etc, revertendo definitivamente sua imagem de cidade inóspita;

- Considera estratégico começar a navegação permanente pelo Rio Pinheiros, numa ação administrativa integrando os setores transporte e saneamento.

Isto posto, destacam-se as seguintes avaliações:

- turismo: evidência favorável total e contrária nula;

- carga: impõe-se que carga seja evidência contrária total;

- Passageiros: idem

- Trem tem que olhar o rio e interagir com corpo d'água e margens;

- Intermodalidade trem - barcos deve necessariamente começar; seu desempenho em Santo Amaro e Pinheiros é que definirá a sua extensão para as demais estações;

- Metrô tem que enxergar o Rio Pinheiros;

- Intermodalidade Metrô-barco deve ser implantada;

- Prioridade para sociedade: São Paulo deve assumir-se como cidade mundial;

- Turismo viabiliza hidrovia. 
Anexo IV: Avaliação do Especialista $\underline{\mathbf{d}}$ Eng $^{\circ}$ Sérgio Eduardo Fávero Salvadori 
Engo SÉRGIO SALVADORI - Entrevista Final em abril 2004.

\section{$\underline{\text { Currículo sucinto }}$}

Nascido em Itu, 1946, engenheiro civil pela EESC-USP, 1969, atuou como engenheiro projetista de saneamento básico e de sistemas metroviários de 1970 a 74 . Ingressou no Metrô em janeiro de 1975, no setor de projetos como analista de projetos senior, e foi sucessivamente supervisor de equipe de projetos, coordenador de projetos, chefe de departamento de projeto civil, gerente de projeto civil e, a partir de abril de 2003 Diretor de Engenharia e Construção.

\section{$\underline{\text { Argumentos de Avaliação (Especialista d) }}$}

- Origens do desenvolvimento de São Paulo: opção rodoviarista explica 270 km de Trem Metropolitano com processo acelerado de melhoria e Metrô com 59 km implantados, com ampliação de 2,9 km na Linha 2 e 12,8 km na Linha 4 previstos para 2008;

- Toda decisão, inclusive a navegação do Rio Pinheiros, é um "mix" dos aspectos técnicos, estratégicos e políticos;

- Toda decisão deve ter aderência com a Missão do Metrô;

- Preparou-se avaliação da Proposição com enfoque na renda dos usuários;

- Considerou-se o horizonte de tempo de projeção como sendo compatível com o planejamento estratégico da rede do Metrô, que leva em conta que em 04 anos a Linha 4 estará em operação comercial.

A Avaliação do Especialista foi apresentada com um conjunto de argumentos adicionais, os quais são transcritos integralmente a seguir:

\section{SOB O FOCO METRÔ - SP}

Ao analisar o documento apresentado devo, em princípio, fazer alguns comentários que orientarão minha avaliação sobre o tema. 
Os usuários do Metrô pertencem às várias classes sociais, de $\mathrm{A}$ a $\mathrm{D}$, com forte predominância da classe média (B2 + C do Critério Brasil) da ordem de 69\% com perfil socioeconômico conforme tabela abaixo.

\begin{tabular}{|c|c|}
\hline Homens & $54 \%$ \\
\hline Jovens (entre 18 e 34 anos) & $53 \%$ \\
\hline $\begin{array}{l}\text { Classe social (Classe média B2 }+\mathrm{C} \text { do Critério } \\
\text { Brasil) }\end{array}$ & $69 \%$ \\
\hline Renda média familiar & $\mathrm{R} \$ 2.400,00(10 \mathrm{SM})$ \\
\hline Renda média individual & $\mathrm{R} \$ 1.272,00(5,3 \mathrm{SM})$ \\
\hline Instrução (ensino médio completo) & $51 \%$ \\
\hline Exercem funções burocráticas/subalternas & $39 \%$ \\
\hline Têm vinculo empregatício & $62 \%$ \\
\hline Usuários habituais ( 3 ou mais dias por semana) & $84 \%$ \\
\hline Viagens exclusivas a trabalho & $65 \%$ \\
\hline Usuários de outra condução conjugada ao Metrô & $71 \%$ \\
\hline Acesso à Internet & $59 \%$ \\
\hline Posse de carro & $56 \%$ \\
\hline Residentes nas regiões & $\begin{array}{l}\text { Leste: } 30 \% \\
\text { Sul: } 24 \% \\
\text { Grande São Paulo: } 18 \%\end{array}$ \\
\hline
\end{tabular}

(Fonte: Relatório da Gerência de Operações do Metrô - Caracterização Socioeconômica dos Usuários e seus Hábitos de Viagem - 2003)

Os usuários da classe $\mathrm{B} 2+\mathrm{C}$ são aqueles para os quais o preço da passagem do Metrô afeta significativamente seu orçamento e por tal motivo são aqueles mais 
susceptíveis a abandonar o sistema nas crises de desemprego e redução salarial. Representam, ainda, o maior contingente de usuários.

São também aqueles que utilizam o sistema de transporte procurando alternativas de menor custo, otimizando seu orçamento.

Os de classe A, ao utilizarem o sistema Metroviário o fazem para seu conforto para atingir seus clientes ou fornecedores situados em locais cujo acesso rodoviário é comprometido ou consomem seu tempo de forma a prejudicar seus negócios. São em número muito reduzido Não poucas vezes utilizam helicópteros ou motoristas particulares embora, neste último caso, haja a influência negativa da perda de tempo pelos congestionamentos. Para o sistema Metroviário, são poucos os casos de utilização. São também aqueles que tem opção de lazer mais sofisticada, preferindo naturalmente o transporte individual e procuram lazer fora da cidade.

Já os da classe B, utilizam o sistema Metroviário e ferroviário local, tanto para seu transporte individual quanto para eventual lazer nos fins de semana. A Companhia do Metrô tem incentivado o uso do sistema para o lazer dos fins de semana que, no entanto, tem apresentado resultados não tão satisfatórios quanto esperado, atingindo, no entanto, mais as classes C e D.

O passageiro do Metrô, durante os dias úteis é, portanto, um usuário contumaz do sistema tão somente para se deslocar de seu trabalho à sua casa, no menor prazo possível e no menor custo. Caso seja obrigatória a integração com outros meios de transporte, procurará a de menor valor e a de menor tempo de duração.

A pesquisa da Gerência de Operações do Metrô (ver referência na tabela) mostrou que os usuários do metrô procuram, nos fins de semana, realizar atividades fora de casa, principalmente em espaços públicos ( 30\%) como cinemas/teatros, barzinhos/danceterias, igrejas e parques. As outras respostas expressivas se referiram a atividades mais reclusas como ficar em casa $(22 \%)$ ou ir à casa de amigos $(15 \%)$ ou a trabalho (13\%). A ida ao teatro/cinema/barzinhos e danceterias esta relacionada aos mais jovens (55\% entre 18 e 34 anos) e cuja renda familiar é mais elevada (35\% entre 5 a $8 \mathrm{SM})$.

Quando indagados sobre a utilização de transporte coletivo para a realização de atividades de fim de semana, um pouco mais da metade das declarações não incluía o uso deste meio para se deslocar. Entre a demanda do Metrô existe, portanto, um 
público que tem o seu lazer fora do ambiente doméstico, mas que faz pouco uso do metrô para realizar as atividades recreativas. Quando se analisa a posse do carro entre os usuários do metrô verifica-se que 56\% deles afirmam possuir automóvel, sendo que seu uso ocorre por motivo passeio/lazer por $60 \%$ destes usuários. Diante deste fato fica difícil implementar ações que possam modificar o hábito do uso do carro para realização de atividades de lazer, a não ser que estejam associadas ao uso deste modo.

Isto posto, minha avaliação quanto ao grau de evidência favorável $\left(\mu_{1}\right)$ na opção “manter tráfego de passagem" é alta e estimo o valor de $\mathbf{0 , 9}$ porque os usuários que trafegarão pela Linha 4 - Amarela não abandonarão o sistema para se integrar aos barcos pois terá à sua disposição a Linha C da CPTM, com menor tempo de transferência para atingir a Região Sul ou Oeste a menos que o custo do transporte hidroviário the traga substancial redução de preço que o motive a sair do sistema e transferir para outro onde sua espera seja menor. Por esta última afirmativa estimo que o grau de evidência contrário à proposição de tornar o Canal do Rio Pinheiros navegável seja $\mu_{2}=\mathbf{0 , 3}$.

Quanto a opção "implantar integração metrô-barco-trem na Estação Pinheiros" o grau de evidência favorável $\left(\mu_{1}\right)$ é estimado em $\mathbf{0 , 6}$ baseado na possibilidade de haver interesse da população dos bairros da Zona Oeste - notadamente os moradores da Rodovia Castelo Branco (principalmente se o Tietê tornar-se também navegável), da Rodovia Anhangüera (principalmente os moradores de Pirituba e região) e especialmente aqueles que moram nas margens das Represas de Guarapiranga e Billings — de utilizarem um meio mais rápido para acessar a rede Metroviária, pois deixariam de enfrentar o congestionamento da circulação dos ônibus na região da Lapa, Vila Hamburguesa, Interlagos, Capela do Socorro e Grajaú embora do Rio Tietê à Estação Pinheiros a distância seja curta, de apenas 5 $\mathrm{Km}$, desmotivando os usuários a mudar o meio de transporte. Resta, finalmente, tecer considerações sobre o grau de evidência contrária à proposição na opção "implantar integração metrô-barco-trem na Estação Pinheiros". Neste caso, as populações situadas às margens das represas seriam favorecidas o que faz diminuir o grau de contrariedade à proposição desde que não sejam implantadas outras integrações em outras estações como a de Santo Amaro. Estimo o valor de $\mu_{2}=\mathbf{0 , 7}$. 


\section{SOB O FOCO CPTM}

Manter tráfego de passagem: Valem as mesmas considerações que foram feitas ao Metrô, porém, com um fator de agregação. Está nos planos da CPTM o prolongamento da Linha $\mathrm{C}$ até o Grajaú atendendo assim, as regiões marginais à Billings. O grau de evidência favorável $\left(\mu_{1}\right)$ é estimado em $\mathbf{0 , 9 5}$. Já quanto ao grau de contrariedade à proposição estimo ser baixo $\left(\mu_{2}=\mathbf{0 , 3}\right)$ em virtude da possibilidade da criação de sistemas de barcos nas Barragens da Billings e Guarapiranga adentrando pelo Rio Pinheiros.

Quanto à integração modal trem-barco em Santo Amaro o grau de evidência favorável a permanência dos passageiros nos barcos parece-me muito baixa porque os passageiros vindos do Sul, na primeira oportunidade possível, e ela seria na estação Santo Amaro se transferirá para o sistema Metroferroviário por ser mais seguro e atender uma parcela maior da Região Metropolitana. Estimo valor $\mu_{\mathbf{1}}=\mathbf{0 , 3}$. Pelas mesmas razões estimo $\mu_{2}=\mathbf{0 , 2}$.

Já para a integração modal adicional trem-barco na Estação Pinheiros estimo grau de evidência favorável $\mu_{1}=\mathbf{0 , 2}$ porque o nível de atendimento de transporte aos moradores da região oeste é maior do que o da zona sul. Some-se ao fato que o interesse em permanecer no barco em direção ao sul, pelo Rio Pinheiros, só teria sentido sob o prisma turístico porque aquele que se utilizaria de transporte para o trabalho ou se integraria ao sistema Metroferroviário ou viria de ônibus ou trem. Quanto ao grau de evidência contrário à proposição estimo valor superior da integração modal trem-barco em Santo Amaro pelos mesmos motivos anteriormente apresentados porque o nível de atendimento aos usuários da região oeste é maior do que o da zona sul em termos de transporte público. Assim $\mu_{2}=\mathbf{0 , 5}$ parece ser um bom valor.

Para a integração modal adicional em mais quatro estações o grau de evidência favorável seria baixo pelo fato do usuário procurar logo se integrar ao sistema Metroferroviário, fazendo-o em Pinheiros ou Santo Amaro. Além disso, para manterse no sistema barco ao longo do Rio Pinheiros teria que enfrentar uma demorada operação na eclusa da Estação Elevatória da Traição. Estimo um valor de $\mu_{1}=\mathbf{0 , 3}$. Para o grau de evidência contrário o valor estimado para outras integrações é alto, 
porém, considerando passageiros que se deslocam do sul ou do oeste, que tem seu trabalho próximo às estações intermediárias não seriam contrários à essa integração estimo algo em torno de $\mu_{2}=\mathbf{0 , 8}$.

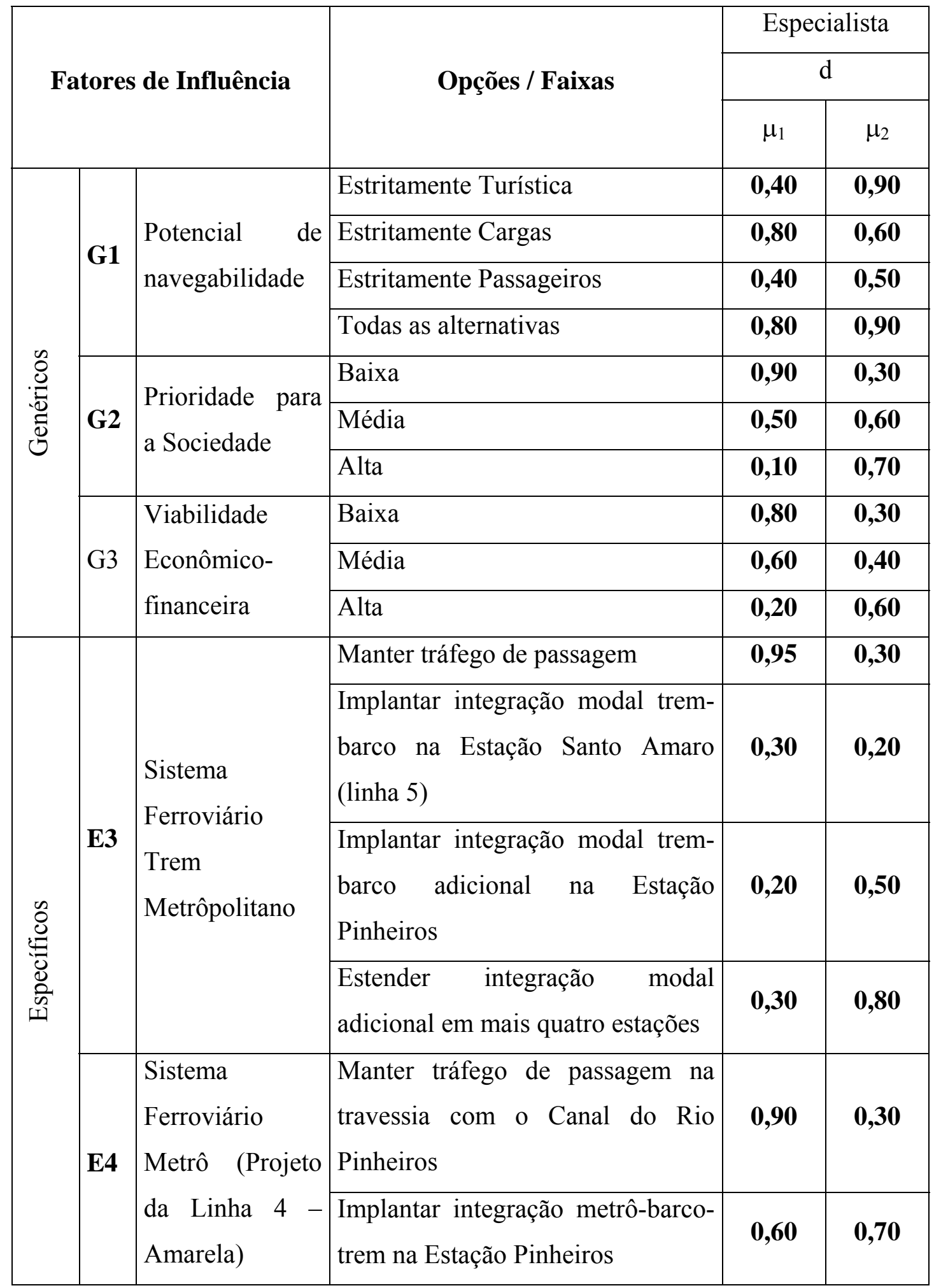


Anexo V: Avaliação do Especialista $\underline{\mathbf{d}}$ Eng $^{\circ}$ Silvio Leifert 
ENG $^{0}$ SÍLVIO LEIFERT - entrevista final em abril de 2004

\section{$\underline{\text { Currículo sucinto }}$}

Engenheiro civil, pela Universidade Mackenzie em 1977, ingressou na SABESP em 1979, participou das $2^{\mathrm{a}}(22 \mathrm{~m} 3 / \mathrm{s})$ e $3^{\mathrm{a}}$ etapas $(33 \mathrm{~m} 3 / \mathrm{s})$ da ETA - Guaraú, da implantação da ETA - Taiaçupeba $(5 \mathrm{~m} 3 / \mathrm{s})$ desde a concepção à pré-operação como chefe da obra, engenheiro residente; coordenou o Projeto Tietê Programa de Despoluição da Bacia do Alto Tietê /1ª Etapa (final de 1994 a abril de 1996); foi superintendente do PMA - Programa Metropolitano de Água (abril 1996 a março de 2000); a partir de março de 2000, exerceu a Coordenação Geral da $2^{\mathrm{a}}$ Etapa do Projeto Tietê até março de 2003. Atualmente é responsável pelo departamento de Desenvolvimento Tecnológico da SABESP.

\section{Argumentos de Avaliação (Especialista e)}

\section{Para os Fatores Genéricos}

- Cargas: não acha prioritário; potencial grande de passageiros na margem esquerda e os serviços de transportes para turismo;

- Acredita em ação político-administrativa integrada, assumida por entidade Metropolitana, associando Estado - Municípios, ou mediante convênio que os integrem;

- Prioridade para sociedade : prioridade é média, pois compete com setores vitais como habitação e saneamento, mais prioritários;

- Viabilidade financeira: compartilhada com outros setores que limpam as águas e propiciam acessibilidade às margens;

- Resíduos: não necessariamente são negativos e geram benefícios indiretos.

Para os fatores específicos:

- E1: eventual é o mais provável;

- E2: margem esquerda é mais viável; 
- E3: integração modal trem-barco deve ser implantada em Santo Amaro Pinheiros;

- E4: Estação Pinheiros do Metrô deve integrar-se ao canal;

- E5: todo o fator e as faixas tem evidência favorável total;

- E6: considera que o desempenho das ETEs não condiciona qualidade das águas no Pinheiros; são independentes no seu ponto de vista;

E7 e E8: devem ser permanentes. 
Anexo VI: Avaliação do Especialista $\underline{\mathbf{f}}$ Prof. Aristides Almeida Rocha 
PROF $^{\circ}$ ARISTIDES ALMEIDA ROCHA- Entrevista final em abril de 2004

\section{Currículo sucinto}

Nascido no Rio de Janeiro, reside em São Paulo desde os 5 meses de idade, tem atualmente 68 anos. Teve toda sua formação educacional em São Paulo, em escolas públicas. Formou-se em 1966 pela FFCL - Faculdade de Filosofia Ciências e Letras, atual Instituto de Biociências da USP, em Ciências Biológicas. Trabalhou durante toda sua graduação e desde 1961 (um ano antes de ingressar na faculdade) era estagiário do Museu de Zoologia sob direção de Paulo Emílio Vanzolini. Durante a graduação atuou como estagiário e curador da coleção de insetos aquáticos, sob orientação do entomólogo Karol Lenko. Ingressou na CICPAA - Comissão Intermunicipal de Controle de Poluição das Águas e do Ar, nos municípios do ABCDM, onde permaneceu até 1968, sendo chefe do laboratório de Biologia. Em seguida permaneceu 2 a 3 meses na COMASP. Ainda em 1968, ingressou na CETESB, o então Centro Tecnológico de Saneamento do FESB - Fomento Estadual de Saneamento Básico, cuja sede era a ETA do ABV da COMASP. Em 1969 ingressou como docente voluntário e em 1973, foi contratado como auxiliar de ensino da Faculdade de Saúde Pública da USP. O primeiro curso para operadores de estações de tratamento de água e esgotos foi ministrado no ABV para cerca de 30 operadores em 1973. Permaneceu na CETESB até 1989, onde chegou até superintendente de impactos ambientais, tendo atuado na área de pesquisa e treinamento em água e esgoto, com ênfase em esgoto. Desenvolveu estudos inéditos em Limnologia nas represas do Estado de São Paulo, iniciando com a Represa de Americana, o Reservatório Billings, o Reservatório Guarapiranga, o Rio Tietê, etc. Em 1989, aposentou-se da CETESB, passando a ser tempo integral na FSP/USP, onde foi chefe do Departamento de Saúde Ambiental, Vice Diretor em duas gestões e atualmente Diretor.Desde 1972 é consultor da OMS/ OPS, BID e BIRD, UNIDO, etc.

Foi precursor da utilização de organismos de fundo de corpos d'água (macroinvertebrados bentônicos) como indicadores biológicos da qualidade de água. 
Em relação aos corpos d'água da região de São Paulo, sua vasta experiência permite identificar os processos ambientalmente mais viáveis de recuperação da sua vida aquática.

\section{$\underline{\text { Argumentos da Avaliação (Especialista f) }}$}

Todas as avaliações consideram que a efetividade do Projeto Tietê apenas se inicia, com grande possibilidade de presença de vida aquática em todos os trechos do Canal do Pinheiros, pela iminente conclusão e operação das principais obras de coleta e interceptação.

Considera também viável integrações dos diversos modais de transportes situados nas margens dos rios através de estações de trem e metrô e de estacionamentos associados à possibilidade de conexão com atracadouros e portos.

Considera que a Proposição representa um grande potencial para cargas e passageiros, principalmente se forem associadas às demais alternativas; quanto à prioridade para a sociedade e viablidade do empreendimento, a avaliação é totalmente favorável, pela carência de oferta de equipamentos similares na cidade. 
Anexo VII: Avaliação do Especialista g Sr. Hélio Oliveira da Silva 
SR. HÉLIO OLIVEIRA DA SILVA - entrevista final em 2004.

\section{$\underline{\text { Currículo sucinto }}$}

Nascido em Itaguaí em 1953, registrado em Montes Claros - MG; estudou até $8^{\text {a }}$ série em Bataguaçu (MS) e Presidente Epitácio (SP). Com 13 anos operava máquinas de terraplenagem em MS, em obras de estradas de rodagem. Teve por força da profissão do pai, que morar em várias regiões do Brasil, acompanhando a implantação de obras rodoviárias; é contratado aos 18 anos como operador de máquinas, tendo trabalhado sucessivamente em MS, MG, RJ e SP. Na cidade de São Paulo, participou da implantação de 5 avenidas de fundo do vale, como encarregado de máquinas (como um exemplo, a Av. Eliseu de Almeida sobre o Rio Pirajussara). Ingressou no serviço público em 1976, na Regional do Butantã do Município de São Paulo; ficou 4 anos em Campo Limpo e o restante em Butantã. Começou como operador de máquinas assumindo as funções de Chefe de Unidade e Encarregado Geral, tendo incorporado todos esse cargos; atualmente é Assessor Técnico em obras emergenciais e de rotina da Sub-prefeitura do Butantã.

\section{Argumentos de Avaliação (Especialista g)}

Considera grande o potencial da navegação de cargas, associando-se a uma grande demanda da sociedade pelo sistema hidroviário. Avalia que sua implantação é viável. Considera que os afluentes do Canal do Rio Pinheiros necessitam de manutenção do Poder Público e que a participação da população no agravamento do problema inundações é pequeno; calha tem que estar limpa.

Considera viável dar continuidade à prática de limpeza pública em favelas, com participação de equipes de apenas três funcionários e atividades básicas de varrição; avalia que a favela Sapé no Butantã constitui o principal problema de limpeza pública da sub-prefeitura do Butantã.

Considera o aspecto drenagem de grande complexidade para operação, o que teria conseqüência na dificuldade de manter níveis d'água no canal adequado à navegação. 
Anexo VII: Avaliação do Especialista $\underline{\mathbf{h}}$ Geógrafo Carlos Eduardo Guimarães do Nascimento 
Geógrafo CARLOS NASCIMENTO - entrevista final em Abril de 2004

\section{$\underline{\text { Currículo sucinto }}$}

Nascido em São Paulo, com bacharelado (1985) e licenciatura (1986) plena em Geografia pela USP. Trabalhou no Departamento de Meio Ambiente da ELETROPAULO de 1994 a 1997, e no Departamento de Gestão Ambiental da EMAE de 1998 até a presente data. Representa a EMAE em vários colegiados, destacando-se o Sub-comitê da Bacia Hidrográfica do Alto Tietê / Pinheiros Pirapora, desde 1998, ocupando atualmente a secretaria executiva com mandato 2003 e 2005. Dentro de suas responsabilidades na EMAE destaca-se a atuação na área de licenciamento ambiental em geral, trabalho com comunidade e questões relativas às licenças ambientais dos serviços desassoreamento do Canal do Rio Pinheiros.

\section{$\underline{\text { Argumentos de Avaliação (Especialista h) }}$}

- Turismo: não há evidência favorável;

- Carga: mais viável;

- Passageiros: não há evidência favorável;

- Geral: viável;

- Prioridade: baixa em geral;

- Viabilidade: pouco viável;

- Geração : inviabiliza navegação;

- Acessibilidade: evidência favorável aumenta;

- Sistemas ferroviários: é favorável à integração;

- Tratamento de esgotos: está de acordo com indicadores biológicos;

- Sistema de drenagem: o voto $(1,0 ; 1,0)$ decorre do conflito inerente à navegabilidade e ao controle de cheias; o COS - Centro de Operação do Sistema da EMAE pode ampliar competências e relacionar-se com SAISP Sistema de Alerta a Inundações de São Paulo para esta objetivo;

- Sistema de resíduos sólidos; dragagem pode interferir na navegação;

- Sistema esgotos coleta e interceptação: não há voto. 


\section{REFERÊNCIAS BIBLIOGRÁFICAS}

ABE, J.M. \& J.I. DA SILVA FILHO, Manipulating Conflicts and Uncertainties in Robotics, Multiple-Valued Logic and Soft Computing, V.9, ISSN 1542-3980, 147169, 2003.

ABE, J.M. \& J.I. DA SILVA FILHO, Para-analisador e suas Aplicações em Robótica, Coleção Documentos, Série Lógica e Teoria da Ciência, IEA-USP, Nº 49, 24p., 2003.

ABE, J.M. \& J.I. DA SILVA FILHO, Uma teoria de tomada de decisão frente a dados contraditórios ou difusos, em Tópicos Emergentes em Engenharia de Produção, Vol. 01, Org. J.P.A. Fusco, Arte \& Ciência Editora, ISBN 8574730912, São Paulo, 249-262, 2002.

ABE, J.M., A. SCALZITTI \& J.I. DA SILVA FILHO, Introdução á Lógica para a Ciência da Computação, Editora Arte \& Ciência, São Paulo, ISBN 85-7473-045-9, 298 págs., 2001.

ABE, J.M., Aplicações do Para-analisador, Coleção Documentos, Série Lógica e Teoria da Ciência, IEA-USP, Nº 50, 76p., 2003.

ABE, J.M., B.C. ÁVILA \& K. NAKAMATSU, Paraconsistent Annotated Logic Programming - Paralog, International Journal of Computing Anticipatory Systems, vol. 6, 51-65, 1999.

ABE, J.M., Fundamentos da Lógica Anotada, Tese de Doutorado, FFLCH - USP, 135 pp, 1992.

ABE, J.M., Some Aspects of Paraconsistent and Applications, Logique et Analyse, 157(1997), 83-96. 
ABIKO, ALEX K. “Deteriorização das Cidades”, 1992.

ACKOFF, Russel L. "Redesigning the Future - a System Approach to Societal Problems”. Editora John Wiley \& Sons, EUA, 1974.

ALVES, Alaôr Caffé, Lógica, Pensamento Formal e Argumentação: Elementos para Discurso Jurídico, Edição Profissionais Ltda, 2002.

ANSAY,P. e SCHOONBROPT, "Pensar la Ville - Choix des tectes philosophiques”, Edição AAM, Bruxellas, 1989.

ASSY, Tufi Mamede, “Mecânica dos Fluídos”, Livro texto da disciplina de graduação da EPUSP, Editora Grêmio Politécnico, São Paulo, 1994.

ÁVILA, B.C., J.M. ABE \& J.P.A. PRADO, Reasoning in Paraconsistent Frame Systems, The Second International Workshop on CSCW in Design, P. Siriruchatapong Z. Lin \& J. P. Barthes (Eds), International Academic Publishers, ISBN: 7-80003-412-7/TP.19, Bangkok, Thailand, pp. 239-244, 1997.

ÁVILA, B.C., Uma Abordagem Paraconsistente Baseada em Lógica Evidencial para Tratar Exceções em Sistemas de Frames com Múltipla Herança, tese de Doutoramento, Universidade de São Paulo, São Paulo, 1996.

BASTOS, Celso Ribeiro. “Os prefeitos e sua ganância institucional” in Estado de São Paulo, pag. A2, 24/4/2001.

BLAIR, H. A. and V. S. SUBRAHMANIAN (1987), Paraconsistent Logic Programming, Proc. 7th Conference on Foundations of Software Tech- nology and Theoretical Computer Science, Lecture Notes in Computer Science, vol. 287, 340360, Springer- Verlag.

COHEN, Guy Modélisation des réseaux urbains, Editions CNRS, França, 1995. 
Comunidade Econômica Européia, Conselho. "Diretriz 93/38 definindo a coordenação de procedimentos para outorga de mercados dos setores de água, energia, transportes e telecomunicações, modificada pela Diretriz 98/4”. Página WEB da CEE [http:europa.eu.int], 6 páginas A4, 2000.

COX, Earl. “Fuzzy fundamentals”. IEEE Spectrum, EUA, 1992.

DA COSTA, N.C.A., J.M. ABE \& V.S. SUBRAHMANIAN, Remarks on annotated logic, Zeitschrift f. math. Logik und Grundlagen d. Math. 37, pp 561-570, 1991.

DA COSTA, N.C.A., J.M. ABE, J.I. DA SILVA FILHO, Patente de Controlador Lógico Paraconsistente, data do depósito no INPI 04/05/2000, no. do pedido PI 0001759, 2004.

DA COSTA, N.C.A., J.M. ABE, J.I. DA SILVA FILHO, A.C. MUROLO \& C.F.S. LEITE, Lógica Paraconsistente Aplicada, ISBN 85-224-2218-4, Editôra Atlas, 214 págs., 1999.

DA COSTA, N.C.A., V.S. SUBRAHMANIAN \& C. VAGO, 'The paraconsistent logics P $\tau$, Zeitschrift fur Math. Logik und Grund. der Math. 37,137-148, 1991.

DA SILVA FILHO, J.I. \& J.M. ABE, Algoritmo Para-analisador - Parte I: um algoritmo para tratamento de inconsistências em sistemas de controle, Coleção Documentos, Série Lógica e Teoria da Ciência, IEA-USP, $n_{0}$ 43, 18p., 1998.

DA SILVA FILHO, J.I. \& J.M. ABE, Algoritmo Para-analisador - Parte II: aplicação do operador negação (NOT) e dos conectivos da conjunção (AND) e da disjunção $(O R)$ da lógica paraconsistente anotada de anotação com dois valores Coleção Documentos, Série Lógica e Teoria da Ciência, IEA-USP, $\mathrm{n}_{\mathrm{o}}$ 44, 15p., 1998.

DA SILVA FILHO, J.I. \& J.M. ABE, Algoritmo Para-analisador - Parte III: propostas de aplicações do algoritmo da lógica paraconsistente anotada de anotação 
com dois valores - LPA2v em sistemas especialistas de Inteligência Artificial, Coleção Documentos, Série Lógica e Teoria da Ciência, IEA-USP, $\mathrm{n}_{0}$ 45, 15p., 1998.

DA SILVA FILHO, J.I. \& J.M. ABE, Algoritmo Para-analisador - Parte IV: propostas de aplicações do algoritmo da lógica paraconsistente anotada de anotação com dois valores - LPA2v em sistemas de controle de Robôs, Coleção Documentos, Série Lógica e Teoria da Ciência, IEA-USP, $\mathrm{n}_{\mathrm{o}}$ 46, 22p., 1998.

DA SILVA FILHO, J.I. \& J.M. ABE, Fundamentos das Redes Neurais Paraconsistentes - Destacando Aplicações em Neurocomputação, Editôra Arte \& Ciência, ISBN 85-7473-045-9, 247 págs., 2001.

DA SILVA FILHO, J.I. \& J.M. ABE, Fundamentos das Redes Neurais Paraconsistentes - Destacando Aplicações em Neurocomputação, Editôra Arte \& Ciência, ISBN 85-7473-045-9, 247 págs., 2001.

DA SILVA FILHO, J.I. \& J.M. ABE, Introdução á Lógica Paraconsistente Anotada com Ilustrações, Editora Emmy, Santos, ISBN 85-901597-1-X, 166p., 2000.

DA SILVA FILHO, J.I. \& J.M. ABE, Métodos de Aplicações da Lógica Paraconsistente Anotada de Anotação Com Dois Valores-LPA2v com Construção de Algoritmo e Implementação de Circuitos eletrônicos, Boletim Técnico da Escola Politécnica da USP, Departamento de Engenharia de Computação e Sistemas Digitais, ISSN 1413-215X, BT/PCS/9906, 17p.,1999.

DA SILVA FILHO, J.I. \& J.M. ABE, Paraconsistent analyser module, International Journal of Computing Anticipatory Systems, vol. 9, ISSN 1373-5411, ISBN 29600262-1-7, 346-352, 2001. 
DA SILVA FILHO, J.I. \& J.M. ABE, Paraconsistent electronic circuits, International Journal of Computing Anticipatory Systems, vol. 9, ISSN 1373-5411, ISBN 29600262-1-7, 337-345, 2001.

DA SILVA FILHO, J.I., J.M. ABE \& P.L. SANCHES, Circuitos de portas lógicas primitivas implementados a partir de uma classe de lógicas paraconsistentes anotadas, Boletim Técnico da Escola Politécnica da USP, Departamento de Engenharia Eletrônica, ISSN 1413-2206, BT/PEE/9723, 13p.,1997.

DA SILVA FILHO, J.I., Métodos de interpretação da Lógica Paraconsistente Anotada com anotação com dois valores LPA2v com construção de Algoritmo e implementação de Circuitos Eletrônicos, EPUSP, Tese de Doutoramento, São Paulo, 1999.

DUPUY, Gabriel e TARR, Joel, Les réseaux techiniques urbains, in Annales de la Recherche Urbaine, Ed. DUNOD, Paris, 1984.

DUPUY, Gabriel e TARR, Joel, Technology and The Rose of the Networked City in Europe and America, Editora da Temple University, EUA, 1998.

DUPUY, Gabriel, L’Urbanisme des Réseaux - Théories et Méthodes, Editora Armand Colin, Paris, 1991.

FERRAZ, J.C. Figueiredo, Urbis Nostra, EDUSP, 1991.

GRIGG, Neil S. “Infrastructure Engineering and Management”. Editora John Wiley \& Sons, EUA, 1988.

LATTS - Laboratoire Techniques, Territoires et Societés, página WEB da École de Ponts et Charussées [http://www.enpc.fr/latts/gouvres.htm], 3 páginas A4, 2001. 
MONTICELLI, Alair e GARCIA, Ariovaldo. “Introdução a Sistemas de Energia Elétrica”. Edição Imprensa Oficial do Estado de São Paulo e Editora UNICAMP, São Paulo, 2000.

MOSLEY, P. e McKERCHAR, A. "Capítulo 8, Streamflow do Handbook of Hydrology”. Editora McGrau Hill, EUA, 1992.

NELSON, Priscilla P. et all. "Final Report based on the Workshop of Integrated Research for Civil Infrastructure”, página WEB da New York University [http://www.nyu.edu/urban/research/nsf-infra/report.html], 76 páginas A4 e apêndices, 1997.

PRADO, J.P.A. \& J.M. ABE, Um Planejador Baseado em Lógica Paraconsistente. 20 Simpósio Brasileiro de Automação Inteligente, Curitiba, pp. 177-178, 1995.

PRADO, J.P.A., Uma Arquitetura em IA Baseada em Lógica Paraconsistente, tese de Doutoramento, Universidade de São Paulo, 1996.

SANTOS, Milton. “A Natureza do Espaço, Técnica e Tempo. Razão e Emoção”. Hucitec, São Paulo, 1999 (3ª edição).

SANTOS, MILTON. "Caminhos de reflexão sobre a Cidade e o urbano”, organizado por Ana Fani Alessandri Carlos, EDUSP, 1994.

SANTOS, Milton. "Metrópole Corporativa Fragmentada: o caso de São Paulo”, Livraria Nobel, Secretaria de Estado da Cultura, São Paulo, 1990.

SCHULZ, David F. "What is Infrastructure", página WEB do Infrastructure Tecnology Institute da Northwestern University [http://www.iti.nwu.edu/def_infr.html], 4 páginas A4, 2000. 
SILVA, R.T. “A Conectividade das Redes de Infra-Estrutura e o Espaço Urbano de São Paulo nos Anos 90” São Paulo”, mimeo FAU-USP, 1999.

SOUZA, Podalyro Amaral de, "Histerese em Escoamento sobre Salto-de-esqui". Tese de Doutoramento à EPUSP, São Paulo, 1985.

SUBRAHMANIAN, V.S., On the Semantícs of Quantítatíve Logíc Programs, Proc. 4th IEEE Symposium on Logic Programming, Com- puter Society Press, Washington D.C., 173-182, 1987.

SYLVAN, R. \& J.M. ABE, On general annotated logics, with an introduction to full accounting logics, Bulletin of Symbolic Logic, 2, 118-119, 1996 (Abstract).

TAVARES, Luis V. e outros. "Investigação operacional”. Edição do Instituto Superior Técnico/Lisboa e Editora MacGraw Hill de Portugal, 1996.

VELTZ, Pierre. “Temporalités et represéntations de l’efficacité: la ville, les territoires, l'entreprise” in “Ces réseaux Qui nous gouvernent?” sob direção de Michel Gariépy e Michel Marié, Éditions L’Harmattan, Paris, 1997.

YEE, Cheng Liang. "Quantificação de Variáveis Subjetivas no Projeto”. Mimeo, 1999.

ZMITROWICZ, Witold e De Angelis, G.Infraestrutura Urbana, PCC/EPUSP,1997.

ZMITROWICZ, Witold, “A conceituação de fluxo em estruturas urbanas e regionais”, mimeo, PCC/EPUSP, São Paulo, 2002.

ZMITROWICZ, Witold, “A Estruturação da Cidade pelas Rotinas Urbanas” Tese de Livre Docente à EPUSP/PCC, São Paulo, 1997. 
ZMITROWICZ, Witold, “Estruturação Urbana: Conceito e Processo”, Boletim Técnico do PCC/EPUSP, São Paulo, 1998.

ZMITROWICZ, Witold, “O sonho e a realidade do Plano de Avenidas”, Revista do Departamento do Patrimônio Histórico da Secretaria Municipal da Cultura, Ano III, nº 4, São Paulo, 1996. 